Florida International University FIU Digital Commons

\title{
Create, Establish, Maintain: Comparing Zones of Peace in the Nordic Area and the Southern Cone
}

Dylan W. Roberts

Florida International University, drobe012@fiu.edu

DOI: $10.25148 /$ etd.FI14071178

Follow this and additional works at: https://digitalcommons.fiu.edu/etd

\section{Recommended Citation}

Roberts, Dylan W., "Create, Establish, Maintain: Comparing Zones of Peace in the Nordic Area and the Southern Cone" (2014). FIU Electronic Theses and Dissertations. 1555.

https://digitalcommons.fiu.edu/etd/1555 


\title{
FLORIDA INTERNATIONAL UNIVERSITY
}

Miami, Florida

CREATE, ESTABLISH, MAINTAIN: COMPARING ZONES OF PEACE IN THE

NORDIC AREA AND THE SOUTHERN CONE

\author{
A thesis submitted in partial fulfillment of the \\ requirements for the degree of \\ MASTER OF ARTS \\ in \\ INTERNATIONAL STUDIES \\ by \\ Dylan W. Roberts
}

2014 
To: $\quad$ Interim Dean Michael R. Heithaus

College of Arts and Sciences

This thesis, written by Dylan W. Roberts, entitled Create, Establish, Maintain: Comparing Zones of Peace in the Nordic Area and the Southern Cone, having been approved in respect to style and intellectual content, is referred to you for judgment.

We have read this thesis and recommend that it be approved.

Eduardo Gamarra

Astrid Arrarás

Félix Martin, Major Professor

Date of Defense: May 14, 2014

The thesis of Dylan W. Roberts is approved.

Interim Dean Michael R. Heithaus

College of Arts and Sciences

Dean Lakshmi N. Reddi

University Graduate School

Florida International University, 2014 
(C) Copyright 2014 by Dylan W. Roberts

All rights reserved. 


\section{DEDICATION}

To April, Emory, and my parents for your indefatigable love, patience, and support; and to Eduardo and Félix for lighting the fire. 


\section{ACKNOWLEDGMENTS}

Throughout my formal training as a scholar in International Relations, interest in peace has always seemed implicit rather than explicit. Often, my professors would add in their final wrap-ups of their courses that the end goals of the research discussed therein would further the goal of instilling a norm of peace in an unforgiving international system. It struck me as odd that the goal of peace would, apparently, be relegated to afterthought status in the study of International Relations; however, over time, I became accustomed to this routine, and I perceived as a preference to present oneself as disinterested and unattached. Indeed, the potential for being labeled just another leftist, liberal (in a nonacademic sense) or sympathetic voice among a phalanx of perceived peaceniks likely played a role in the choices of my esteemed instructors who aimed to present a pragmatic, theory-oriented view of the way that states interact with each other. The genesis of this thesis has its roots in a seminar that I took that focused on the distinct, if small, body of literature explicitly devoted to the possibilities of peace. Far from espousing a cause, the subject matter took aim at examining the underpinnings of peace and answering the essential question of whether peace or war is the norm and its converse the exception.

The crux of the research herein presents itself in a comparison of two of the world's most peaceful geographical groupings: the Nordic area and the Southern Cone of South America. It bears mentioning that meaningful analysis of these two groupings requires not only significant background knowledge related to each area, but also rigorous theoretical training on the concepts explored herein. Integral in establishing and strengthening this work have been the invaluable scholarship and guidance of the 
esteemed professors who were kind enough to lend their time and guidance to this pursuit, and I recognize them with no order in mind. I am forever indebted to Eduardo Gamarra for the contribution of his comprehensive practical and theoretical expertise in politics, particularly in the Americas. Without his efforts, the comparative aim that the current research takes would be haphazard to the detriment of its conclusions. Also, for the thoughtful, encouraging, and exacting stewardship of Félix Martín I am unceasingly grateful. His instruction on peace studies was not only responsible for introducing the (sub)field to me, but his provocative approaches to the concepts it covered, and genuine interest in answering some of the core questions of peace studies were responsible for both challenging and nurturing my understanding of peace in the ever-evolving international system. Finally, but by no means least important, I would like to thank Paul Kowert. Dr. Kowert's detailed and precise instruction is primarily responsible for the great leaps I have made in communicating through scholarship. Without the benefit of Paul's instruction, my ability to communicate effectively and conduct meaningful research would have been insufficient to meet the demands of this undertaking, which also benefits from his careful analysis. The interested instruction and frank conversation with each of these three professors has not only raised the quality of the final product on the pages that follow, but also helped to cement a solid foundation for scholarship in the years to come.

It would be imprudent for me to gloss over the important contributions of other professors and colleagues, without whom the quality of this research could not be fully realized. For the time spent discussing the specifics of this topic and the prudent guidance 
on the achievement of goals, I would like to thank sincerely Drs. Thomas Breslin and Markus Thiel. Both were instrumental in shaping the research through helping to undergird area studies methodologies and their instruction was constitutive to my growth as a scholar. I could not have produced this research without their trenchant insights. Few peers have had such a positive impact on the quality of my work, in a classroom environment and in collegial settings, as Nicolás Terradas. A brilliant scholar of Argentine extraction, I can only hope to one day have such a meaningful impact on his career moving forward as he has mine. For his considerable knowledge of peace in the Southern Cone, I am forever grateful.

Lastly, and most importantly, I would like to thank my family for unwavering support during times that would likely strain relationships in any other family. As we welcomed our daughter during the latter stages of this research, our parents and relatives (who are spread out rather inconveniently) coalesced and provided us with support that few superlatives can accurately describe. In the final stages of this process, my mother's editorial expertise proved invaluable to the crafting of a product I could be proud of. More important, my wife has taken the stresses of motherhood in amazing stride and has been nothing if not perfect in her new role as a mother and her continuing one as a partner through the sometimes-challenging course of life. Without her love and her help, my performance as a father and as a scholar would doubtless suffer. Whatever successes are achieved through the completion of this scholarly endeavor are largely a product of April's love and strategic spurring, and without her advice and undying faith in my abilities, I would surely not have been able to complete this work. 
ABSTRACT OF THE THESIS

CREATE, ESTABLISH, MAINTAIN: COMPARING ZONES OF PEACE IN THE

NORDIC AREA AND THE SOUTHERN CONE

by

Dylan W. Roberts

Florida International University, 2014

Miami, Florida

Professor Félix Martín, Major Professor

In the wake of the Cold War, regional organizations have proliferated and are now a dominant theme in global politics. This study tests whether explanations for the Nordic peace can help to understand or construct other zones of peace in these increasingly important regional settings. With that in mind, this study compares the Nordic area of Denmark, Finland, Iceland, Norway, and Sweden with the Southern Cone region-here defined as Argentina, Chile, Paraguay, and Uruguay-and both are treated as regional, subsystemic zones of peace. Its significance lies in analysis of two developmentally disparate regions not yet compared in zones of peace literature. Using structured, focused comparison, this study is guided by fundamental questions about each region that assess the relationship between explanations for regional peace and their respective historical records. Understanding the conditions that permit the endurance of peace in today's global context has far-reaching empirical and theoretical implications. 


\section{TABLE OF CONTENTS}

CHAPTER

PAGE

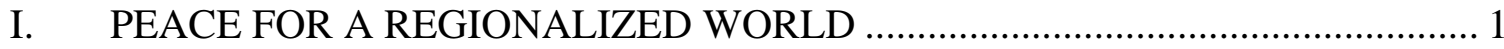

Placing the Comparison in Context ...............................................................4

What Are Zones of Peace? .......................................................................11

Clarifying Terms: Democracy, Peace, and Regions .....................................18

Separating the Nordic Area and Southern Cone Zones of Peace ....................23

Comparing the Nordic Area and Southern Cone...........................................28

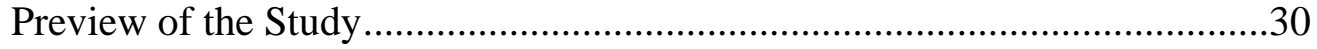

II. EXPLORING THE NORDIC AREA ZONE OF PEACE …................................ 33

The Nordic Area in Geographical Context ...................................................35

The Nordic Area as a Zone of Peace .........................................................39

Explaining the Nordic Zone of Peace ..........................................................63

Conclusions: Assessing the Zone of Peace in the Nordic Area.....................76

III. A ZONE OF PEACE IN DEVELOPING WORLD: THE SOUTHERN

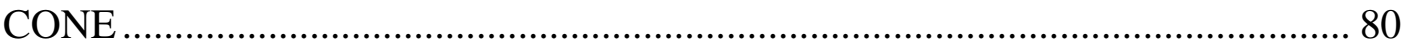

The Southern Cone in Geographical Context................................................83

Constructing a Narrative: Regional Peace in the Southern Cone ...................90

Testing Hypotheses in Light of the Historical Record .................................124

Conclusions: Assessing the Southern Cone Zone of Peace.........................130

IV. THE NORDIC AREA AND THE SOUTHERN CONE IN COMPARATIVE

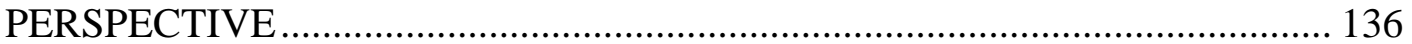

Comparing Diverse Zones of Peace .......................................................137

Explaining the Maintenance of Peace in the Nordic Area and the

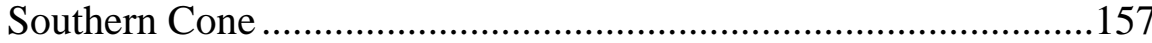

Conclusion: New Directions for Future Research? ....................................178

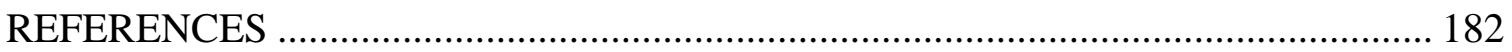




\section{LIST OF TABLES}

TABLE

PAGE

Table II.1: Years of Independence and Democracy for Each Nordic State..................... 56

Table II.2: Years of Last Violent Confrontations for Each Nordic State ........................ 57

Table III.1: Independence in the Southern Cone ...................................................... 99

Table IV.1: Comparing the Nordic Area and the Southern Cone................................. 156

Table IV.2: Explanations for the Maintenance of Peace in the Nordic Area and the Southern Cone .................................................................................. 178 


\section{LIST OF MAPS}

MAP

PAGE

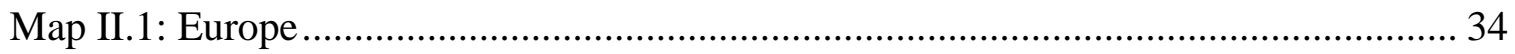

Map II.2: The Nordic Area ..................................................................................... 36

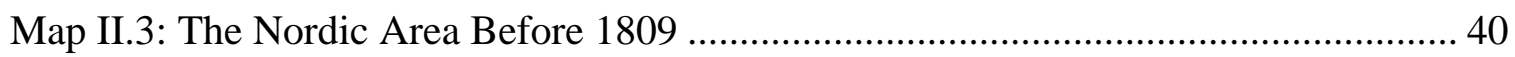

Map II.4: Post-Napoleonic Nordic Area .................................................................... 45

Map II.5: The Nordic Area in the Inter-War Period (1926) .............................................. 52

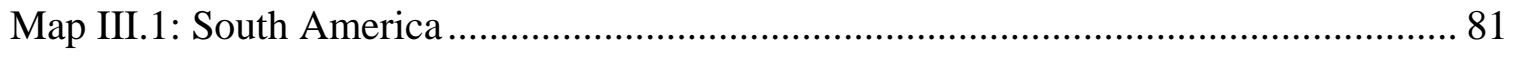

Map III.2: The Southern Cone ................................................................................. 82

Map III.3: The Southern Cone (Detail).......................................................................... 89

Map III.4: Colonial South America .................................................................................... 91

Map III.5: Post-Independence South America, 1826......................................................... 98

Map III.6: War of the Triple Alliance (Paraguayan War), 1864-1870 .............................. 99

Map III.7: Disputed Claims and Resolution to Beagle Conflict..................................... 105

Map III.8: The Falklands War (1982)........................................................................ 106

Map III.9: The Chaco War, 1932-1935 …………………............................................ 107 


\section{ABBREVIATIONS AND ACRONYMS}

ASEAN

BCE

CE

CELAC

EU

HDI

Mercosur or Mercosul

NATO

Norden

OAS

OECD

UCR

UN

UNASUR
Association of Southeast Asian Nations

Before Current Era

Current Era

Community of Latin American and Caribbean States

European Union

Human Development Index

Common Market of the South

North Atlantic Treaty Organization

Term used by the Nordic Council and in scholarship to refer to the Nordic area

Organization of American States

Organization for Economic Cooperation and Development

Radical Civic Union

United Nations

Union of South American Nations 


\section{PEACE FOR A REGIONALIZED WORLD}

A frequent criticism of the Nordic area's value to peace research, or to understanding its mechanisms and applying them to regions more broadly, is that its case is too exceptional to be useful. That is, in the prevailing view of many scholars, understanding peace in the Nordic area-Denmark, Iceland, Finland, Norway, Sweden, and those states' respective home rule territories-carries little value to peace research beyond its initial aims. ${ }^{1}$ By contrast, my research challenges that assumption by offering an opposing view: that the Nordic experience is indeed valuable to peace studies, particularly within the zones of peace approach-meaning a scholarly attempt to understand or categorize groups of states that do not take up arms against one another-and that understanding the causes of peace in the Nordic region can lead to better understanding of why peace endures and through what means. ${ }^{2}$ To support the claim, the present study offers a comprehensive overview of the Nordic area as a region, a distinct zone of peace, and a model for understanding peace elsewhere in the world.

The current study is guided by an essential question, what can the Nordic zone of peace teach us about regional peace more broadly? To answer the question, Nordic peace will be compared to another zone of peace: the Southern Cone. The states of the Southern Cone compose another of the world's exceptional zones of peace-defined here in minimal terms as an absence of intraregional interstate violence-and are often the subject of some debate. Though this debate over the Southern Cone’s limitations will be carried

\footnotetext{
${ }^{1}$ Wæver 1998: 72; Archer and Joenniemi 2003: 199; Browning and Joenniemi 2012: 7-8

2 See George 1992; Singer and Wildavsky 1993; Kacowicz 1995, 1998; Archer and Joenniemi 2003
} 
out more fully in the coming chapters, the region should be understood herein as comprising four states: Argentina, Chile, Paraguay, and Uruguay. One of the most compelling reasons underlying this comparison is that, at the surface level, the realities of peace in the Southern Cone are manifestly different than those in the Nordic area. Despite remarkably divergent paths through history, both regions have maintained internal peace among neighbors with whom interstate relations traditionally entailed violent confrontation. The current study compares the two to assess the similarities and differences in their respective peace processes with aims of divining valuable clues that could be instructive in understanding, and constructing, peace going forward.

Peace itself, irrespective of its environment, remains an understudied concept in traditional international relations scholarship, but some seminal contributions from some of the discipline's luminaries have contributed to a small but significant body of literature. ${ }^{3}$ Within that body of literature, many important authors espouse a zones of peace approach that helps to model peace at the ever more important subsystemic, regional level. Within zones of peace literature, comparative case studies remain relatively rare, but rarer still are comparisons involving the developing world. Arie Kacowicz's 1998 tome, Zones of Peace in the Third World: South America and West Africa in Comparative Perspective addressed both of the literature's shortcomings admirably, but fell prey to what I perceive as another pitfall of the dominant perspectives

\footnotetext{
${ }^{3}$ The referred to body of literature on peace studies evolved in earnest from Karl Deutsch et al.'s Political Community and the North Atlantic Area: International Organization in the Light of Historical Experience (1957); and continued development through seminal works such as Johan Galtung's "Violence, Peace, and Peace Research,” (1969); Kenneth Boulding’s Stable Peace (1978); Anatol Rapoport's Peace: An Idea Whose Time Has Come (1992); among others.
} 
on zones of peace. The comparison did little to bridge the intuitive, conceptual divide between the developing and developed worlds and left each to be compared within only their own economic spheres. The current study aims to bridge that divide by comparing zones of peace in the Southern Cone and the Nordic area with aims to develop some important generalizations about maintaining peace.

Certain conceptual and geographical discussions must take place so that salient conclusions about peace in each region can be drawn, as well as some about peace more broadly in both empirical and theoretical terms. Broadly speaking, there remains considerable debate over the geographies of each region, and the way the regional contours are defined will be consequential in the derivation of solid, far-reaching conclusions. Moreover, Nordic exceptionalism must be explained and the reasons given for such a designation, because the cleaving away of the Nordic states from Europe-as well as that of the Southern Cone states from South America-has not traditionally taken firm root in the body of zones of peace literature. Frequently, each region is packed into a much larger zone of peace (Western Europe since 1945, and South America since 1883 [to 1996], respectively). One of the central contentions of the current study is that each deserves to be considered as unique on its continent and that more geographically symmetrical and conceptually pure units of analysis will lead to more meaningful conclusions about peace. My argument will be explored in some detail throughout the research that follows.

In any case, the existing comparative literature on zones of peace has, as yet, had relatively little to say about either region; thus it is hoped that my work can contribute 
depth and texture to discussions of peace in both Europe and South America. My research aims to understand peace, particularly its understudied endurance, by comparing both regions as distinct zones of peace. Leading hypotheses about the maintenance of the Nordic peace will be discussed in relation to its history of peace, and the analysis of the Southern Cone will test for the presence of those same conditions.

Using this methodology, my research attempts to identify key commonalities and key differences in the onset and the long-term endurance of peace in some of the world's longest established zones of peace (i.e., those that meet the criteria adopted here and in Kacowicz 1998). This study does not aim to assess or assert causation from the factors tested here, but it is hoped that the identification of these commonalities and differences can form the basis for future research that tests the presence of these factors in other zones of peace. The overarching goal of this research is to add to the body of comparative zones of peace literature by placing two disparate zones of peace side by side and assessing what commonalities exist in both areas, and determining the empirical and theoretical implications of those commonalities for the construction of zones of peace elsewhere throughout the world.

\section{Placing the Comparison in Context}

The proposed study to be undertaken is grounded in, and justified by, the following goals:

\section{Furthering a model for peace reflective of today's regionalized global order.}

Understanding peace in today's global order necessitates a focus on regional alignments. Emphasis on global institutions or 'world' alignments (e.g., First World, Second World, 
etc.) is waning, yet the pace of organization continues unabated in the wake of the Cold War. The world's states are moving rapidly toward greater organization at the regional level, and many scholars have hailed regionalization's increased importance in the contemporary context as a sine qua non of the modern global construct. ${ }^{4}$ As ideas of a globally orchestrated peace fade into obscurity and suffer from diminished enthusiasm, states around the world have displayed a surprising proclivity for regionally maintained order, particularly at the economic and political levels, but also in terms of security. The proliferation of regional agreements, institutions, and organizations designed to increase cooperation, trade, and security (or, as the realist argument might contend, to allow the founding states a diplomatic outlet for their power) are a certain testament to this new reality of the contemporary global system. To be sure, global organizations such as the International Monetary Fund, the United Nations, the World Bank, or the World Trade Organization continue to carry considerable weight in the international system, but a decline in their influence and the enthusiasm for global prescriptions is difficult to deny. For a variety of reasons, states with linked histories, shared economies and languages, and geographic proximity are choosing to align like never before, putting aside longstanding rivalries in favor of greater, if uneasy, integration and progress. ${ }^{5}$

To that end, my research is grounded in the assertion that, in light of the rapid rise in regional organization, the zones of peace approach to understanding pacification in a

\footnotetext{
${ }^{4}$ See Adler and Barnett 1998: 16; Kacowicz 1998: 8-9; Archer and Joenniemi 2003: 19. Nye 1968 contends that the cleavage between global and regional organization was visible at the UN's foundational conference in San Francisco, California, and has long been a significant feature of the global system.

${ }^{5}$ The term, "align” should be taken literally in this and other instances in this chapter. Its use is not intended to spark debate on the realist concept of balance of power.
} 
contemporary context could not be more timely or appropriate. With that in mind, this research embraces a subsystemic view of peace, citing shortcomings in both systemic and dyadic views of peace. Specifically, where debate on systemic peace is often divided into systems of democratic regimes and non-democratic ones (Singer and Wildavsky 1993: 3; Kacowicz 1998: 8), at least one, and possibly both, of the examples under analysis present significant challenges to the validity of such a viewpoint. At the other end of the units of analysis debate for peace is a dyadic approach. It would be difficult indeed to view conclusions about peace in a dyadic relationship as applicable to broader systems. Could one credibly assert that regional, or global peace would align with the form and function of a dyadic relationship? Could one simply rely on broader peace to be governed as if it were dyadic peace writ large? Additionally, the dyadic approach presents a potential researcher with an unwieldy and ever-changing dataset from which salient, lasting conclusions would be difficult to draw, owing to the number of dyadic cases that the world's states present. Thus, with the shortcomings of both the dyadic and systemic approaches to understanding peace fleshed out, a subsystemic, regional approach to peace seems best suited to understanding of peace as it exists, or is most likely to exist, in today’s regionally-oriented global setting.

\section{Adding depth to the extant catalog of zones of peace case studies.}

Though venerable peace scholars have treated both the Nordic area and the Southern Cone through the utilization of the zones of peace approach, neither has taken root in the canon as unique, distinct entities, separate from larger and more muddled zones of peace. As will be discussed in some detail later in this chapter, the most prominent works in 
zones of peace scholarship more frequently identify Western Europe and South America as zones of peace, despite rather obvious flaws in the latter's designation. My work notes that, were one to look at both regions as separate from the continents on which they are located, there would be greater value to the furtherance of peace studies, and greater clarity lent to the zones of peace approach. The Nordic area's zone of peace predates that of Western Europe by 130 years and remains uninterrupted. Similarly, the zone of peace that developed in the Southern Cone precedes its larger South American counterpart by more than a decade, and continues unabated. Though each of the larger zones of peace have proven valuable in peace research, their applications are either flawed or ignorant of the more established zones of peace on their perimeters, thus leaving potentially elucidating aspects of peace, and peace maintenance, un- or only partially discovered.

Furthermore, the intuitive imbalance of peace and domestic militarized conflict has too often prevented thorough analysis of the Southern Cone. Its peace appears an afterthought to many who employ and study the zones of peace model because its states for so long lacked fully democratic governance, were prone to horrific internal violence, and were viewed as unimportant or unstable economies. ${ }^{6}$ In light of the advancements on all these fronts of the last two to three decades, the Southern Cone has begun to receive more attention, but the catalog of treatments of the region as a zone of peace remains

\footnotetext{
${ }^{6}$ Although Chile suffered from several brief interruptions in democratic order in the post-1870 period, there is a recurring narrative of total stability until 1973 that I find misrepresents the country's history with democracy. This assertion includes Chile and reflects my view.
} 
deficient. ${ }^{7}$ Too often, zones of peace research focuses on the developed, advanced democracies of Australasia, Europe, and North America, but my research, like Adler and Barnett (1998) and Kacowicz (1998) before it, is grounded in correcting that imbalance. The Southern Cone's addition to comparative case studies within zones of peace literature serves to correct a bias, unintentional though it may be, that is both decidedly Eurocentric and steadfastly focused on comparing cases within intuitive economic boundaries.

\section{Providing a novel comparison of peace in regions previously un-linked within zones of} peace literature.

With the above in mind, the novel tack adopted herein further justifies my research. Rather than adhering to the boundaries of economic status, as so many other comparative zones of peace studies do, I ignore them. Though the one-policy-fits-all approach has been discredited time and again in studies of policy and politics, particularly regarding attempts to aid the developing world, this study allows for and acknowledges indigenous differences between contrasting regions. While allowing for domestic or intraregional differences between the Nordic states and those of the Southern Cone, the current study attempts to compare commonalities and differences in the ways that they have managed their respective long periods of peace. That is, there will be no prescriptions for peace architecture built on best-case scenarios (such as Norden-another term for the five Nordic states, a name popularized by the Nordic Council), only a suggested beginning to a

\footnotetext{
${ }^{7}$ The development of the Mercosur/l project, along with economic growth patterns of the last decade, has spawned a wealth of independent analyses of the region on a broad range of topics, such as Easdale 1999; Weintraub 2000; Hira 2003; Phillips 2004; Grimson and Kessler 2005; Oelsner 2005; Porrata-Doria, Jr. 2005; etc. Very few works explicitly treat the Southern Cone as an independent zone of peace, save Hurrell 1998, Kacowicz 1998, Kacowicz, et al. 2000, and Oelsner 2003 and 2005, hence the claim of deficiency.
} 
potential framework based on the commonalities between two economically, geographically, and governmentally diverse and disparate regions. Beyond the aforementioned concerns, I could find no objections in the literature to such a comparison, and believe that it will benefit the course of future research in both the short and long runs.

Interestingly, both examples face legitimate challenges in peace scholarship. While the Nordic example is often dismissed as too exceptional, the Southern Cone appears burdened by the ubiquitous, if implicit, belief that the experiences of the developing world cannot produce valuable conclusions and prescriptions for the developed world. Thus, as will be discussed in the ensuing pages of this study, this is but one commonality between the two regions that is often overlooked. The comparison of these two regions is based fundamentally on the idea that understanding what their peace processes hold in common will be instructive on generalizations about peace, and could help to drive more of the world's regions to the formation of zones of peace through guiding new research on the subject. Certainly, not every influencing event can or will be discussed or discovered here because peace is a decidedly multi-causal process. However, my research uses each region's path to peace as both a heuristic device and a theory-testing one, as its intent is to garner lessons for application elsewhere-in either the developed or the developing world. 


\section{Allowing for a more nuanced appreciation of the effects of democracy on the}

establishment and endurance of zones of peace.

As debate continues over the law-like association between democracy and peace, the current study offers a more textured approach to understanding the relationship between democracy and peace. A review of the maturation of the zones of peace, from their incipient negative phases, to the present day-in which cooperative, pluralistic relationships are secured to varying degrees-offers another angle of insight to the discussion.

Kacowicz (1998: 2) revises the democratic peace theory and extends it to include the provision that democracy is not a necessary condition, although according to him, its advent enhances the quality of peace in a given region. Fittingly, neither of the regions analyzed here entered their periods of peace as groups of fully democratic states at the outset. Their moves over time toward fuller democratic governance caused appreciable shifts in the stability of their respective regions, providing an ample case for analysis of Kacowicz's claims.

Nordic exceptionalism has played a role in the frequent oversight of the fact that the Nordic peace was not always a stable one (a sentiment echoed in Ericson 2003: 24). Viewing its history with an eye toward assessing advances in democratic governance helps to shape the ongoing debate about the relationship between peace and democracy. Contrarily, the Southern Cone frequently falls prey to its anecdotal reputation in quite the opposite fashion from the Nordic area. Although stability and security community formed significantly later in the Southern Cone than in the Nordic area, changes in the quality of 
peace over time are readily perceptible-particularly with regard to regime change-but the correlation is far from perfect in this case and this study will explore in detail why this is so. It bears mentioning that this study is, in itself, not intended as an entry into the larger debate over what constitutes a democratic peace, but rather that both cases pose obvious challenges to some of the theory's core tenets.

\section{What Are Zones of Peace?}

As a necessary preamble to the discussion that this thesis explores, it is critical to the soundness of the research that the model for understanding regional peace herein is clearly defined. Noted peace scholar Clive Archer states (after Kacowicz 1995: 268) that zones of peace are notionally "used to describe both existing relations and desired outcomes.” (Archer and Joenniemi 2003: 3) These existing relations and desired outcomes are characterized by a small, clear set of assumptions about interstate, intraregional relations among groups of states that share, at minimum, geographic proximity. There exists very little mystery within peace literature as to what brings about zones of peace-Kacowicz attributes their onset to the end of war or to decolonization processes (1998: 4); while Singer and Wildavsky (1993) attribute the establishment of zones of peace to democracy and wealthy, person-centric, productive economies-yet there has been surprisingly little research on what explains the persistence of zones of peace over time. Similarly, the disengagement from zones of peace is well-covered territory. In the earliest narrowly defined iterations of zones of peace (Singer and Wildavsky's "wealthy democracies"), all that would be necessary to revert from being a 
zone of peace to a zone of turmoil and development (their term for the opposite of peace) is the return of a credible fear of war.

Later developments in zones of peace research allow for a more minimal expectation-that a zone of peace should be free from interstate violence-and also stipulate the return of violent conflict between states as the end of a zone of peace, whatever the impetus. Once a region has achieved zone of peace status, according to Kacowicz (1998), that status manifests itself as one of three discreet, identifiable gradations (in order of maturation): (1) Negative, precarious peace, for which a minimum stipulation that the region be free from intraregional militarized conflict is sufficient; (2) Stable, positive peace, wherein the expectation of violence between states is minimal and effectively eliminated from state security strategies; and (3) Deutschian, pluralistic security community, whereby mutual expectations of peace have fostered cooperative integration efforts among an alldemocratic group of states with shared political institutions, such as electoral systems, political parties, or judicial systems. ${ }^{8}$

Clive Archer succinctly summarizes the barriers for entry to each gradation within Kacowicz's 1998 framework, noting that the minimum bar is an absence of war (Archer and Joenniemi 2003: 4). More pointedly, he notes that for any region to be designated a negative zone of peace, it only need meet two requirements: (1) "no or little inter-state war in the region;" and (2) "no or little war between the states of the region and other states, and that which there is, the other states initiate.” (2003: 4) Effectively, such stipulations assure the observer that the states in question are on largely pacific footing in

\footnotetext{
${ }^{8}$ This is not intended to represent an exhaustive list of political institutions.
} 
their dealings with other states within the region and without. The next rung of the conceptual ladder reaches stable peace. It should be noted that stable peace is perhaps the best understood of the three gradations, and is well represented in peace literature. ${ }^{9}$ Stable peace entails an upgrade from the minimalist, negative peace, and its tenets include: (1) "no or little armed conflict in the region in the form of civil war or armed uprisings;" and (2) “no or few military interventions by the region's armed forces in other parts of the world (except, arguably, in the form of internationally sanctioned actions)." (Archer and Joenniemi 2003: 4)

The final, and perhaps most difficult to attain form of zone of peace is the pluralistic security community, as outlined by Deutsch et al. (1957). ${ }^{10}$ Two more necessary elements of peace are added to the existing body of requisites and they build on the tenets of stable and negative peace: (1) "there is little or no expectation of [the first four stipulations, as detailed above], thus creating a region of 'low-tension"” (Archer 1996: 452); and (2) "The states in the region have political institutions and democracy in common and are deeply interdependent.” (Archer and Joenniemi 2003: 5) In other words, trust among the region's states is a foregone conclusion by their leaders, and each state's leadership feels reasonably comfortable engaging in economic, political, or security-based integration processes.

\footnotetext{
${ }^{9}$ See Boulding 1978; Kacowicz 2000b; Kacowicz, Siman-Tov, Elgström, and Jerneck 2000; Väyrynen 2000; Kupchan 2010a,b

${ }^{10}$ See Kupchan 2010b for dissenting argument on this matter
} 
Though many zones of peace studies focus on these three gradations, there are three more related to security communities that will prove important as the current research unfolds. Emanuel Adler and Michael Barnett, in their 1998 update on Deutschian security communities, lay out three important, progressive variations on the concept. Nascent, "lascendant, and mature security communities are, minimally, defined by the levels of will and involvement by each state's leaders and citizens in integration projects. Nascent security communities are defined by "increas[ing] their mutual security [and] lower[ing] the transaction costs associated with their exchanges; and/or encourag[ing] further exchanges an interactions” (Adler and Barnett 1998: 50). Adler and Barnett add that the second phase, ascendant, is characterized by "increasingly dense networks; new institutions and organizations that reflect either tighter military coordination and cooperation and/or decreased fear that the other represents a threat; cognitive structures that promote 'seeing' and acting together...and the emergence of collective identities" (1998: 53-Kupchan 2010a, b). Kupchan associates the latter stipulation with the management of stable peace. Finally, the most elevated stage of security community, mature, is reached when "regional actors share an identity and, therefore, entertain dependable expectations of peaceful change...it becomes increasingly difficult for members of this region to think only in instrumental ways and prepare for war among each other” (Adler and Barnett 1998: 55).

It bears mentioning that the present study is not one rooted in the explanation of what constitutes zones of peace, but rather, how one is maintained. As I claim in my thesis, in terms of conditions for the maintenance of their respective zones of peace, the Nordic 
area and Southern Cone have more in common than has been acknowledged previously in the literature. The primary intellectual concern of the research is the determination of commonalities and contrasts in these rarely connected zones of peace. Though each has been discussed as zones of peace to a limited degree, these two long maintenances of peace have yet to be compared directly. It is certainly no guarantee that there are commonalities in what allows for continued peace in both regions, but it is worth exploring whether commonalities exist and discovering what they can tell us about the establishment and maintenance of zones of peace in other, more fractious regions.

Thus, some important questions are developed here that will guide the research as it unfolds: How is the long peace in the Nordic area viewed in peace studies? To that end, how does zones of peace scholarship explain the region’s pacific footing? An important addition to this line of questioning is the drive to detect what effect the adoption and subsequent deepening of democracy have on the quality of peace among the Nordic states? Equipped with answers to these questions, the same line of questioning will be applied to the Southern Cone. What does the comparison mean for the future of peace research from empirical and theoretical standpoints?

In comparing these two regions by the same standards, I intend to tease out implications for peace in general, and perhaps for the zones of peace approach. I compile and examine some alternative, competing, and complementary explanations for continued peace in the Nordic area and then distill these explanations for peace into hypotheses about zones of peace more generally. These hypotheses will be applied to the historical narrative that I construct for each region. Where possible, I identify at what point in both region's 
histories that their states came to be negative zones of peace, as well as at what point they stabilized, and at what point, if any, they reached the pluralistic security community threshold.

Below, I detail these hypotheses that began as explanations for the maintenance of zones of peace in the Nordic area, and to a limited degree, for the maintenance of zones of peace wherever they exist. For testing purposes, each of these assumptions about peace was converted to hypothesis about what I might encounter in detailing the peace of the Southern Cone. Creating the thesis in the assertion that the peace of these two dissimilar regions endures through similar means, I fashioned these as my hypotheses about the continued existence of peace. The following assumptions are presented as explanations for the maintenance of peace offered by scholars in Chapter II, while they function as my testable hypotheses in Chapter III. Numbers ' 1 ' through ' 5 ' are the aggregated explanations for the Nordic peace (Archer and Joenniemi 2003: 8), and '6' represents a general assumption about zones of peace offered by Arie Kacowicz (1995; 1998: 9). Their phrasing is patterned after Kacowicz's in his comparative zones of peace contributions (1998: 5-6):

1. A zone of peace is more likely to be maintained when the region is geographically isolated, thereby lowering strategic importance to great, or continental, powers, and presenting fewer opportunities for conflict.

2. A zone of peace is more likely to be maintained when the states of a given region share a largely homogeneous ethnic and cultural makeup, thereby presenting fewer opportunities for conflict. 
3. A zone of peace is more likely to be maintained when the region's decision makers are bound to opt out of conflictual outcomes by their preference structures, thereby lessening opportunity for conflict.

4. A zone of peace is more likely to be maintained when the region's political culture is characterized by preferences for restraint from decision makers.

5. A zone of peace is more likely to be maintained where interdependence and common political institutions contribute to the formation of a security community.

6. A zone of peace is more likely to be maintained when there is broad 'satisfaction with the territorial status quo' among the region's states.

The hypotheses are not original in their claims or ideation, but the goals of this study make their application unique. It should be reiterated here that the above list of hypotheses is not presented as an exhaustive list of explanations for the establishment or maintenance of zones of peace in the Nordic area, the Southern Cone, or anywhere else. Instead, the test of these hypotheses should be viewed as a heuristic device, designed to distill important generalizations about maintaining zones of peace wherever they may occur.

As other authors have identified, there is no single explanation for the establishment of a zone of peace (see Boulding 1978; Kacowicz 1995, 1998; Archer and Joenniemi 2003, etc.), the creation of peace regimes is multivariate. Such a claim runs directly counter to some interpretations of the democratic peace argument, but the literature review and case studies should present a credible argument that, at least in the contexts of the Nordic area and the Southern Cone, the basic tenets of that argument do not hold. Democracy does 
however appear to play an important role in the evolution of peace in both regions, and through the adoption of Kacowicz's (1998) framework, which details necessary, sufficient, and favorable conditions for peace, I will be able to identify democracy's role more accurately, thus answering the second question.

\section{Clarifying Terms: Democracy, Peace, and Regions}

As a means of answering the above questions effectively, it is first important to clarify some key concepts that the study relies on throughout. It should be noted, and will be discussed in the paragraphs that follow, that one of the chief quarrels with typical explanations of a democratic peace is that so many entries into the debate fail to settle on a rigid definition for the terms that underpin them. More specifically, a lack of settlement-or even debate-within a number of democratic peace contributions over what constitutes peace, or under what circumstances a government earns the distinction of being a democracy, has proved problematic to many democratic peace arguments. Certainly, questions concerning what constitutes either are indicative of a rich, nuanced and continuing debate that I cannot attempt to answer here. The next paragraphs however, should serve to clarify terms essential to the development of this thesis.

\section{Democracies}

As intuitive as a term such as democracy may seem to anyone who lives in the West, considerable debate continues over what qualifies a government that employs superficial tactics of democracy (free elections, fair elections, referenda on constitutional matters) as a fully functioning democracy. Countries exist today that are, at best, governed only nominally as democracies and are commonly referred to as procedural democracies. 
Procedural democracies (wherein the authority that leaders derive extends from the electoral process and not parties, platforms, or allegiances to a stated belief) meet the conventional minimums of free and reasonably fair elections, but the power of the leaders elected is unchecked and is frequently used to induce a dubious agenda-taking advantage of public disenchantment with traditional politics. Procedural democracy is often viewed as necessary, though not sufficient, to qualify a modern nation-state's government as democratic. Procedural democracies are illustrative of the claim that democracy is not a binary condition, but one that moves along a continuum between non-democracy and substantive democracy, just as peace, and zones of peace, do on their own continuums.

Because the term had become so overused and ambiguous as to have little value without explicit qualifications, Schmitter and Karl highlighted the need for greater scrutiny of the term democracy (1991: 67). Their pithy attempt at establishing guidelines for democracy within a post-Cold War framework led them to describe in detail the concepts, principles, and procedures that are foundational to democracy in the post-Soviet epoch. In their view, a governmental system could not be thusly defined unless leaders are directly accountable to the will of their citizens, who act through their elected officials to achieve results and express their values (termed political democracy [1991: 67]). Adding to citizens, rulers, and the public realm, Karl and Schmitter propound one key conceptual component to democracies that this study accepts as essential in drawing the line between developed democracy and nominal (procedural) democracy: space for competition of ideas and values. (1991: 68) If competition is severely restricted or eliminated entirely, the value of the free and fair election system that established a procedural democracy 
diminishes correspondingly. In any case, the delineations between democracies and nondemocracies made by Karl and Schmitter (1991) will be the general guidelines for judging at what point each region discussed here reached democracy, and to what point those democracies might have developed.

Peace

Peace is an especially difficult concept to grasp. For most people, the term conjures up ethereal images of non-violent and altruistic behavior among all the world's peoples. However, when delving into the scholarship that has sprung up around the term, gradients begin to appear that diverge significantly from any utopian concept. Its evolution from a global panacea to a pragmatic agreement between states and among groups of states has seen significant texture added to its definition. What was once a rigid concept began to be debated in earnest, and added to, in the 1960s.

Johan Galtung’s 1969 article on the subject added considerable depth to what was once ubiquitously seen as a fairly facile concept. His Violence, Peace, and Peace Research (1969) added an essential cleavage to the understanding of peace that has ever since affected its employ in scholarship. Dividing peace into negative and positive denominations helped many to make sense of what they were seeing: countries that were far from perfect, but also not at war-sometimes resting peacefully among states with which their historical war footings had been nearly interminable-or countries that had once gone to war, but were now acting to support and strengthen their neighbors as Karl Deutsch et al. (1957) had first described (Galtung 1969: 183-184). The next major development in peace typologies came from Kenneth E. Boulding, who began to treat the 
subject of peace in the 1960s, but whose greatest contribution to the literature came about in 1978: the urtext of Stable Peace. In Stable Peace, Kenneth Boulding establishes a continuum for peace to slide along from Galtung's negative peace (in which peace is, at best, precarious) to a point at which violence is not guaranteed but possible or very likely, and ultimately to Deutsch's security community (where solutions for peace are pluralistic) in which war is unthinkable and cooperation is the norm (1978).

There are certainly valid arguments that the peace required to create, establish, and maintain zones of peace should track more closely with Deutschian security communities, in which civil strife is minimal and military confrontations between states or interventions elsewhere in the world are nonexistent. However, this understanding of peace verges on utopianism and unnecessarily limits the number of cases for analysis. My thesis takes the position that security communities are what each region works towards or has achieved, but that before having done so, each was at peace within their regions. Particularly during a time such as the nineteenth century, limiting or ceasing military conflict intra-regionally is a particularly noteworthy feat. Thus, the negative, stable peace that both the Southern Cone and the Nordic area enjoyed during the nineteenth and twentieth centuries is a sufficient bar to clear for the current research when designating a region or regions as peaceful.

\section{Regions}

Regions, like zones of peace, are claimed by Arie Kacowicz to be a "limited number of states linked by a geographical relationship and by a degree of mutual interdependence.” (1998: 8) Being related, or interconnected in this way gives each state in the grouping 
some influence on the behavior and well being of the others (Nye 1968: vii). Furthermore, according to Kacowicz (after Wriggins 1992; Kaiser 1968; and Buzan 1991), regional subsystems comprise state groupings that are not only geographically close, but also pursue security, economic, and political agreements (1998: 8).

Although the Southern Cone can be conceived of rather neatly with the exclusion of Southern Brazil (for more on this debate, see Chapter III), the geography of the Nordic area is exemplary of problems that continue to confound geographers and political regionalists. Amorphous or non-existent borders interrupted by significant geographical realities-primarily large bodies of water-make easy assessment of some of the world's regions or sub-regions impossible. Accordingly, it is broadly accepted that a degree of arbitrariness is included in a regional or sub-regional designation. That is, those who wish to debate the number of countries included in a region such as the Southern Cone would be reasonably valid in claiming a composition of three to six countries credibly; however, it is often stipulated that preponderant weighting is ceded to geographical and cultural and/or identity connectedness (Kacowicz 1998: 8). The latter condition adds subjectivity to arbitrariness, so this should be taken into consideration when assessing the validity of my selections or those of others.

The importance of regional analysis to the present study and to others is that it allows the researcher to credibly pursue a relatively underused unit of analysis: subsystems. The importance of subsystemic analysis rests in no small part in the proliferation of regional organizations that aim to connect continents or regions through goals of peace, security, and prosperity; as opposed to a global initiative to do the same, the influence and efficacy 
of which appear to be on the wane. Subsystemic analysis also allows this study to benefit from disaggregation of the democratic system as a whole, providing for more trenchant insight into the machinations and qualities of peace in a specialized setting in which democracy was not the dominant form of governance despite peace being the norm. Analysis through subsystems allows us to identify more accurately (using the previously mentioned standard of negative peace) the zones around the world that can benefit from attention to the impediments of greater peace.

\section{Separating the Nordic Area and Southern Cone Zones of Peace}

Preeminent in zones of peace research, Arie Kacowicz $(1995,1998)$, more than any other scholar, has identified historical zones of peace, and surprisingly, these zones are often large and sometimes long lasting. Kacowicz presents cases of historical zones of peace in his 1998 book Zones of Peace in the Third World, although his study focuses the bulk of its intellectual pursuit on just two of them. His list of historical zones of peace is as follows: (1) Zones of peace before 1815; (2) Europe, 1815-1848; and (3) Europe, 18711914. He lists contemporary zones of peace as the following cases: (1) Western Europe, 1945 to the present; (2) Eastern Europe 1945-1989; (3) North America, 1917 to the present; (4) South America, 1883 to the present; (5) West Africa, 1957 to the present; (6) Northeast Asia, 1953 to the present (again, this would likely change given recent events; (7) Australasia and the Southwest Pacific, 1945 to the present; and finally, (8) The ASEAN (Association of Southeast Asian Nations) countries, 1967 to the present. These examples, listed in Zones of Peace in the Third World's 1995 forerunner, Explaining 
Zones of Peace: Democracies as Satisfied Powers?, have received broad acceptance in the literature. ${ }^{11}$

Notable exclusions include the two cases this study seeks to illuminate: the Southern Cone and the Nordic area. ${ }^{12}$ In each case, the subsystem brought in for analysis by this study is extracted from a larger region that has long been assumed as firmly within the canon of zones of peace. In both cases, the regions cut away for the purpose of more meaningful examination are exemplary-even given that their larger regions, in the eyes of many, have already earned that distinction.

Although Western Europe is largely viewed as a peaceful and cooperative security community, the peace that the region experiences is short-lived when compared with that of its northernmost members. Peace in the Nordic area has been a reality since the conclusion of the Napoleonic Wars in 1814, far outpacing even the most advanced countries in the rest of Europe or farther afield in Japan or Australasia.

Similarly, South America is often among the more surprising entries into the ranks of zones of peace. For many, the fact that South America has been largely non-violent within its continental boundaries comes as a surprise, largely because of the tragic violence and dictatorial governance that characterized so many of its countries during the twentieth century. Notably, despite prolonged periods of tense international relations

\footnotetext{
${ }^{11}$ See Adler and Barnett 1998 and Archer and Joenniemi 2003.

12 Both of which are acknowledged by other scholars as zones of peace: notably, the Southern Cone by Hurrell 1998 and Oelsner 2003; Kacowicz 1998 emphasizes it but does not explore it fully or separately, and the Nordic area by Archer 1996; Wæver 1998; and Browning and Joenniemi 2012.
} 
within the region, and the occasional war, South America has been largely peaceful since the conclusion of the War of the Pacific in 1883.

What follows then is a brief survey of the zone of peace cases examined for this study and the qualifications that make them excellent examples:

\section{South America from 1883 to the Present}

Scholars have broadly acknowledged South America's place among the world's most peaceful regions, but there is plenty of reason to disqualify the region from a zone of peace designation, even by minimalist definitions. ${ }^{13}$ Largely peaceful relations are not completely peaceful interstate relations as applied to the South American case. Strictly speaking, the major war between Bolivia and Paraguay in the latter half of the 1930s constitutes a full disruption of the post-1883 peace on the continent. Both sides, in what was a historically and geopolitically very important violent conflict, experienced heavy casualties and to ignore this major event would be willful negligence and risks the validity of conclusions built on the peace of the continent. Additionally, the three militarized conflicts between Ecuador and Peru (the last of which was waged between two democracies) during the twentieth century makes the argument of a South American peace increasingly untenable-it strains the conscience to paint the whole continent as a bastion of political resolutions to tense conflicts. Thus, it would be more appropriate to cleave away a particular region that is large and fraught with important players within the region's economic and political landscapes.

\footnotetext{
13 Among those who classify (or acknowledge the classification of) South America as a zone of peace are Kacowicz 1995, 1998; Holsti 1996; Miller 2007; and Oelsner 2005 and 2007.
} 
The Southern Cone from 1870 to the Present

The conclusion of the War of the Triple Alliance (1870) brought interstate fighting in the Southern Cone to an end, and this peace remains unbroken despite tense moments of conflict. To be sure, the cessation of state-on-state hostilities did little in the long-term to prevent the Southern Cone's governments from coming to loggerheads over a multitude of issues, and the threat of violence between rival states never fully disappeared until each state's transitions to non-military democracy was fully implemented (a period that stretched from the mid-1980s until the early 1990s). Perhaps what is most notable about the case of the Southern Cone is that despite every country's being subjugated by regimes that were unafraid of violence, even the most tense moments of crisis between them were resolved universally by political and diplomatic means. These events will come into sharp focus in this study, and the effects of the transition to democracy as well as each country's interactions with South America's important political actors will be examined fully.

\section{Western Europe from 1945 to the Present}

The peace of Western Europe, in the wake of the Second World War's 1945 conclusion, is pregnant with conceptual geneses, but perhaps the most important to the present study is the Deutschian security community (Deutsch et al. 1957). With a continent fully in the grip of a bipolar Cold War system, Karl Deutsch (et al.) saw the formative phases of a relationship that would evolve from a coal and steel union all the way into the fuller security agreement of the North Atlantic Treaty Organization and the European Community (later, the European Union), both of which were incarnations of a European 
mood that not only accepted peace as a norm, but also one geared toward securing the region cooperatively. The depths of the peace in Europe are paradigmatic and have rarely, if ever, come under serious strain since the conclusion of Europe’s last large-scale war. It bears mentioning however, that the depth of the idea of a peaceful Western Europe does not make up for longevity. Though war between any of the Western European states may today be unthinkable (despite considerable economic distress over time), the memory of Francoist Spain, an aggressive Nazi Germany, or Mussolini’s Italy as a willing participant in Hitler's campaign to dominate Europe is too fresh in the minds of scholars for Western Europe to be the standard bearer for a zone of peace model.

\section{The Nordic Area from 1815 to the Present}

Contrary to Europe's relatively recent history of violence, the Nordic area earns the distinction of the world's longest standing zone of peace. The last violence between any of the Nordic states that was waged intra-regionally was done so by Sweden, which did so in 1814 as its tenure as a great European power drew to a close. Within the Nordic area, great power politics has, since the turn of the second millennium CE, been a great game played between the region's two colonial powers. Historically, Nordic regional dynamics were dictated by Denmark, whose perch atop the Nordic power hierarchy went unquestioned until the seventeenth century, when a rising Sweden became the preeminent regional power. Sweden's rise to power was accompanied by a broader recognition as a great power in Europe. As a result of Sweden's conquering of Finland and other Baltic areas, it became firmly entrenched as a power that, at minimum, exercised authoritative preeminence among the Nordic and Baltic states and began to compete on the scale of the 
Russian and German empires of the time. The conclusion of the Napoleonic Wars made signified Sweden's fall from the Continental echelon of power, but also accelerated its competition for dominance in and around the region with the Russian Empire, whose claims to Finland made Sweden's territorial desires all the more pressing. Sweden's violent campaign to subjugate Norway in 1814 was the last time that any Nordic state would exercise military force to resolve an intra-regional dispute, and the countries of the Nordic area have successfully resolved disputes among themselves through political and diplomatic means ever since.

\section{Comparing the Nordic Area and Southern Cone}

Methodologically, as has been stated, the logic of the study is grounded in comparison. To achieve this honestly and effectively, Alexander George's structured and focused methods of comparison (George 2005) is adopted in this study. In the same way that Kacowicz justifies his comparison of South America and West Africa (1998: 25), the current study cannot be, nor does it aim to be, a complete account of each region's history. My presentation of history is heuristic and theory-testing in nature, so the likely omission of occasional historic precedents might be expected. Moreover, my clearly stated goal from the outset is to tease out important challenges that incipient or inchoate peaces must withstand to be sustained or enriched, and also to identify important steps or solutions for peace in the remainder of the world's increasingly important regional groupings.

Despite their occupying differing rungs on the ladder of development, the Nordic area and the Southern Cone maintain some surprising similarities. At the cursory level, each 
occupies an extreme position in relation to much of the world's geography (one in the Far North, another in the Far South). More importantly however, both regions are more developed (possessing stronger economies with better educated and healthier populations by comparison) than the larger zones of peace to which they are frequently attached in scholarship. Moreover, each region has sustained a peace among its member states for far greater lengths of time than those continents with which they are most often connected in the literature, despite dubious odds (though this study makes no attempt to assign causality or judge the level of correlation between these two facts). Both regions' peace trajectories have been heavily influenced by the actions of powerful extraregional actors (namely, but not exclusively, Russia and Brazil). Finally, and this will be explored in greater detail in each region's respective chapter, each region contains an outlier state, whose violent tendencies (my study makes no value judgment on their necessities) toward extraregional states far outpaced and outlasted those of all the other states-in the case of the Southern Cone, the outlier is Paraguay; in the Nordic area, the state in question is Finland. Obvious differences notwithstanding, some intriguing parallels do much to validate the comparison of these two regions.

Given the remarkable set of similar circumstances between these polar opposites, it is indeed worth further investigation to assess whether similar events, or responses to them, helped lead each zone of peace to its present status. Chapters II and III both accept that the explanations for peace offered by varying authors are all worthy of merit, though at the cursory level, it appears that Kacowicz’s (1995; 1998) “satisfaction with the territorial status quo" is an obvious, shared condition between these two zones of peace and further 
likens them enough for comparison. The inverse is also true, the most significant conflicts during these long peaces between the states of the Southern Cone and the Nordic area appear largely to have centered on territorial disputes. Alternative explanations and hypotheses for and about conflict and peace within the two regions this study covers will be fielded as well, but what seems clear at the outset is that territorial disputes will play an outsize role among potential drivers for conflict.

\section{Preview of the Study}

The next two chapters present the two zones of peace cases for examination. In each, treatment of the region in question will begin with a discussion of the region's geography, highlighting key debates, distinctions, and misconceptions surrounding the regions' boundaries or member states. From there, the discussion moves into relatively brief histories of the region's path to sustained peace, delineating important facts about each country's character, major ethnic cleavages, traditional rivalries, and the like.

Where the chapters differ, importantly, is in their intent. Chapter II catalogs the broadly accepted analysis of the contributing factors to the long peace in the Nordic area, as its peace is well documented and equally well understood. After recounting the region's historical record as a zone of peace, a discussion commences regarding those widely accepted views on what allows for the longstanding pacific disposition among the Nordic states. The crux of the discussion in Chapter III lies in the overarching intent of this study. In detail, Chapter III proceeds in identical fashion to Chapter II, however these explanations for peace are treated as plausible generalized assumptions about maintaining zones of peace. With that in mind, the hypotheses are tested against the historical record 
of the Southern Cone. The concise historical narrative is infused with a focus on the six hypotheses (detailed earlier in this chapter), and the conclusion of Chapter III discusses to what degree these predictions are accurate. An additional focus of the historical narrative determines to what effect, if any, the adoption of democratic systems of governance had on the quality of peace. Because the historical narratives for each region are chronological, there is ample opportunity to examine the effect of deepening democracy on their differing gradations of zones of peace (i.e., pre-peace, negative peace, stable peace, security community).

Chapter IV concludes the study analyzing empirical and theoretical implications of my study. The final chapter discusses what was learned about the commonalities and differences in the Nordic area and the Southern Cone zones of peace. The bulk of Chapter IV is rooted in the comparison of the results from the previous chapters. Are there determining variables in the Nordic area that are notably absent in the Southern Cone's long peace? Directly emanating from this comparison is the logical corollary to that discussion: discovering what these commonalities mean for the future of peace research and zones of peace in a broader sense. Chapter IV also assesses whether the beginnings of generalizations about zones of peace are a logical distillation from this study. Is there a strong enough connection between the two regions that, despite differing circumstances, we can infer going forward some formal assumptions about other zones of peace? My study's originating claim that there is indeed a previously unperceived, and deeper than suspected by most, connection between the two regions is discussed in detail. Is there 
anything that this study can tell us about how to prosecute this sort of research in the future, particularly from a methodological or theoretical point of view?

The final chapter focuses heavily on the comparison of each chapter's results, and ponders what this comparison might mean for the future of peace research, particularly the zones of peace model. Possible refinements to zones of peace research are suggested, as are some potential points of departure for new research in the peace studies corner of international relations scholarship. Some surprising developments from each case study's findings serve as particular points of emphasis in the final chapter. The study concludes with a brief discussion on what the comparison of peace in each region revealed about the regions themselves (with particular regard to their applicability to other zones of peace), and about peace more generally, and calls for deeper understanding and wider acceptance of both regions as unique zones of peace. The conclusion summarizes potential conditions for peace in regions around the world. 


\section{EXPLORING THE NORDIC AREA ZONE OF PEACE}

This chapter analyzes the regional relationship among five states in what is commonly referred to as the Nordic area. Denmark, Finland, Iceland, Norway, and Sweden all combine to form a widely acknowledged sub-region (region for the purposes of this research) of Northern Europe. The connections between these countries and the way they have avoided violent conflict among their regional counterparts, are the focal points for the remainder of this chapter. Particularly, the peace is exceptional not only for its length, but also for its transcendence of centuries-old rivalries. The most basic question of how these rivals with a history of violent interstate interactions began to eschew violence makes the case of the Nordic area a frequent target for scholarship. Many peace scholars have sought to understand and explain the Nordic peace, although there is rarely consensus as to what allows these historic adversaries to maintain their current pacific dispositions. This chapter examines the history of the region, particularly after the onset of negative peace, and the explanations that the literature thus far has offered as to why that negative peace lasted and matured into the pluralistic security community that exists today among this now close-knit group of states.

Functionally, the research carried out here concerns more than a simple rehashing of the region's history. This chapter questions the historical record, and seeks answers that could prove illuminating about broader principles of peace and frameworks for regional peace in other regions that are currently beset by conflict. 
Map II.1: Europe

\section{Europe}

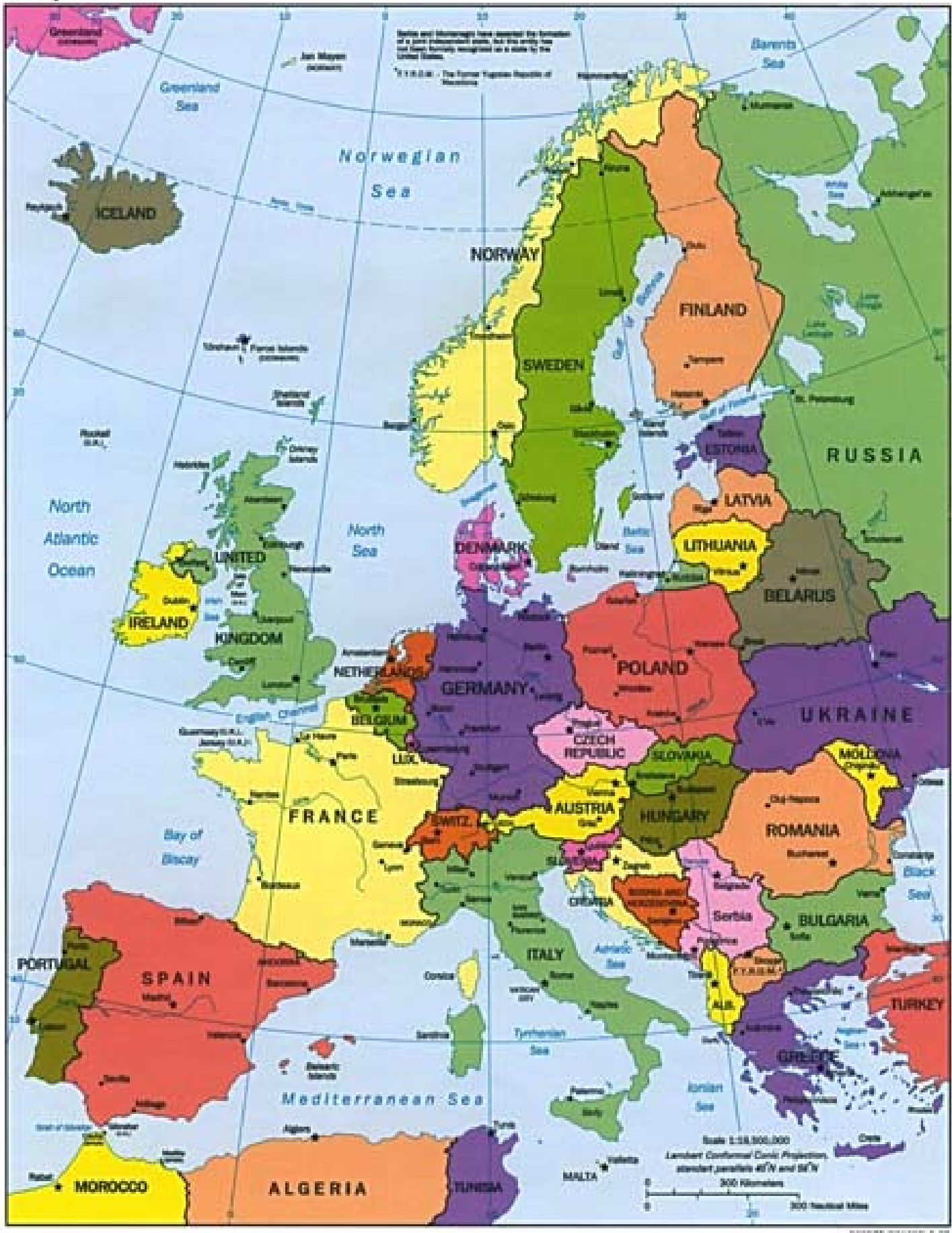


To derive salient conclusions from the historical narrative constructed here, this chapter proceeds with the following goal in mind: to determine whether the Nordic area qualifies as a zone of peace, and whether there is value in examining this sub-region separately from the Western European zone of peace. What can be learned about the Nordic peace that can be constructive for analysis of other cases and for future zones of peace research?

As this chapter concludes, one of the main contentions of this thesis is tested in the succeeding chapters. After distilling some essential truths, and perhaps some surprising conclusions, about the Nordic zone of peace, this chapter leads into the next two by challenging the prevailing wisdom that the Nordic peace is unique and its experiences are not applicable or comparable to other regions. In short, subsequent chapters test the idea that the Nordic example is of little value in generalizing about peace.

\section{The Nordic Area in Geographical Context}

Initially, the geographical limitations of the Nordic area might appear clear, but there are some notable misconceptions that tend to accompany fresh analysis of the region. This section serves to clarify some common misunderstandings about the region's boundaries and included states, while adding clarity to past drivers of conflict problematic in centuries past. Placing the Nordic area in geographical context proves to be crucial in understanding not only how the region came to peace, but also, what factors contribute to its maintenance. 
Map II.2: The Nordic Area

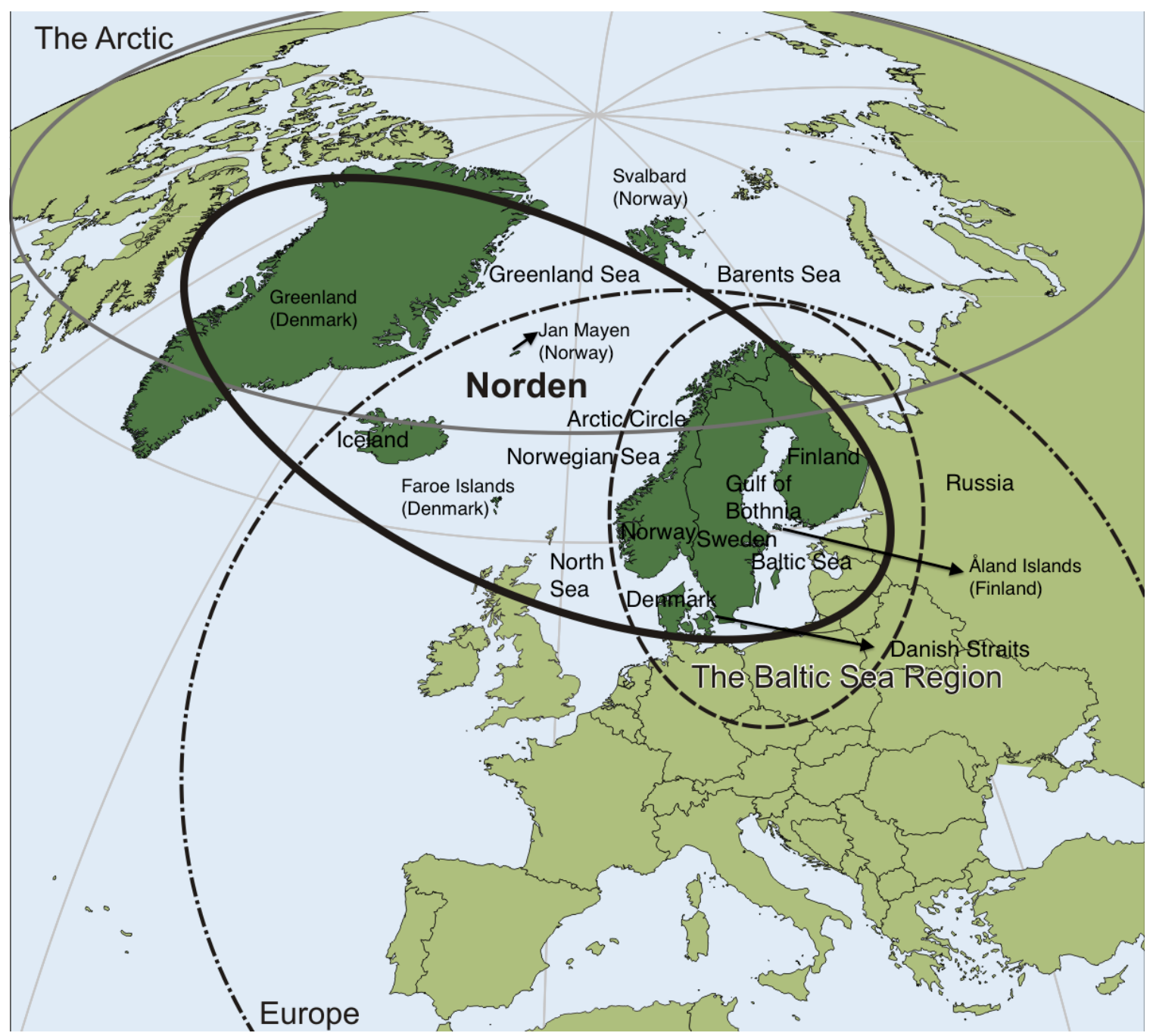

The Nordic region (Norden) is most widely considered to including the countries that currently make up the Nordic Council: Denmark (and its administered territories of the Faroe Islands and Greenland), Finland (along with the once-disputed Åland Islands), Iceland, Norway, and Sweden. Viewing the region through the lens of supranational institutions can be difficult however, as the levels of economic, political, and security integration with broader Europe or Russia is uneven. With that in mind, the delimitations of the physical boundaries of the region that Map II.2 defines as Norden are also 
important to grasp. As a result of Norse exploration in the first millennium CE, Norse language and culture spread westward from its ethno-linguistic hearth in modern-day Sweden. It is this westward explanation across the Norwegian and North Seas that accounts for the spread of Norse language and culture into far afield territories like Greenland, Iceland, and the Faroe Islands.

The Baltic Sea serves as yet another body of water buffer between the Nordic states, barely separating Sweden in the north from Denmark in the south. The thin straits between Copenhagen, Denmark and the southern Swedish cities of Helsingborg and Malmo effectively represented the line upon which regional power balanced for centuries, effectively until the conclusion of the Napoleonic Wars. Nevertheless, the Danish Straits did little to separate Danish culture from the Nordic states to its north. Perhaps because of the long-conflictual relationship between Denmark and Sweden over the right to exercise monarchical influence over the territories of Iceland, Greenland, Norway, and the Faroe Islands, the two are inextricably linked in both cultural and historical terms. The struggle for influence in the region dominated a millennium's worth of relations among the Nordic states, and that history makes their grouping as a region both comfortable and logical from a researcher's standpoint.

The most curious extension of the region's zone of inclusion is Finland. Though a cursory glance at a map of the region makes Finland appear a clear choice for inclusion among the Nordics, a review of its place in the region's history leaves it as something of an oddity. Unlike the Norse-derived languages of its western neighbors, the Finnish language is not mutually intelligible among its Nordic counterparts, although it does 
incorporate a large number of loan words from the Lithuanian language (Arter 1998: 10). While the other four countries and their territories share clear ethnic and linguistic links due to thousands of years' worth of common history and migratory patterns, Finland is largely excluded from those same linkages. The origins of the Finnish people remain anthropologically unclear, but scholars on the subject have, more or less comfortably, surmised that the Finns are descended from a Uralic stock in contrast with the Europoid derivation of the rest of the Nordic states. It is posited that the Finns who migrated from the east settled in Southern Finland, in relative isolation from Nordic movements across the country's north, particularly during the time that the Swedish Vikings founded the Russian Empire (Arter 1998: 11).

In any case, Finnish inclusion in the Nordic area clearly emanates from its close ties with the Swedish, with whom its history is intertwined more than any the other Nordic states. As the Swedish Vikings migrated and colonized eastward (Arter 1998: 11), they settled in Finland's northern territories, and the close ties that those Vikings-cum-Russians developed with the land would place it firmly in the middle of a belligerent tug-of-war between the two countries until the nineteenth century. The region's borders with Russia (in both Finland and Norway) would come to define its easternmost extension in the contemporary context, and also one of its great defining geopolitical struggles that continues even today.

Principally, the debate over the Nordic area's geography centers largely on what is, and is not, considered Scandinavia. Unlike the Southern Cone, ambiguity in the Nordic area is rare and easy to avoid with a clear understanding of 'Scandinavia' as a unit. The most 
important distinction to be made is that, while included in the Nordic area, Finland is not Scandinavian. As was explained here, the cultural, ethnic, and linguistic differences between Scandinavia and Finland are deep and abiding, despite close international cooperation between them in the twentieth century. If one conceptualizes the four Scandinavian countries as those tied together by broadly intelligible, updated variations of Old Norse, then the exclusion of Finland (culturally) is rather uncomplicated. One only need combine the two to compose the appropriate image of the Nordic area.

\section{The Nordic Area as a Zone of Peace}

To understand the peace of the Nordic area, it is essential to understand why the peace is, in-and-of itself, noteworthy. Before the conclusion of the Napoleonic Wars, the royal houses of Denmark and Sweden were locked into seemingly interminable quests for dominance over the region's territories. Though Norway played a more substantive role in driving regional politics than Iceland, and to a lesser extent, Finland, each of these three Nordic states is viewed through the lens of history as successor states. (Arter 1999: 1) The former imperial states of Denmark and Sweden have long been positioned as the major catalysts of regional dynamics, with Denmark serving as the standard bearer of Scandinavian power from the $13^{\text {th }}$ through the $16^{\text {th }}$ centuries, and Sweden following in its place from the $17^{\text {th }}$ through the $19^{\text {th }}$ centuries. (Arter 1999: 1) As these two empires sought to expand their influence, important and interesting political precedents were setting the tone for the pacific community the world recognizes among the Nordics today. 
Map II.3: The Nordic Area Before 1809

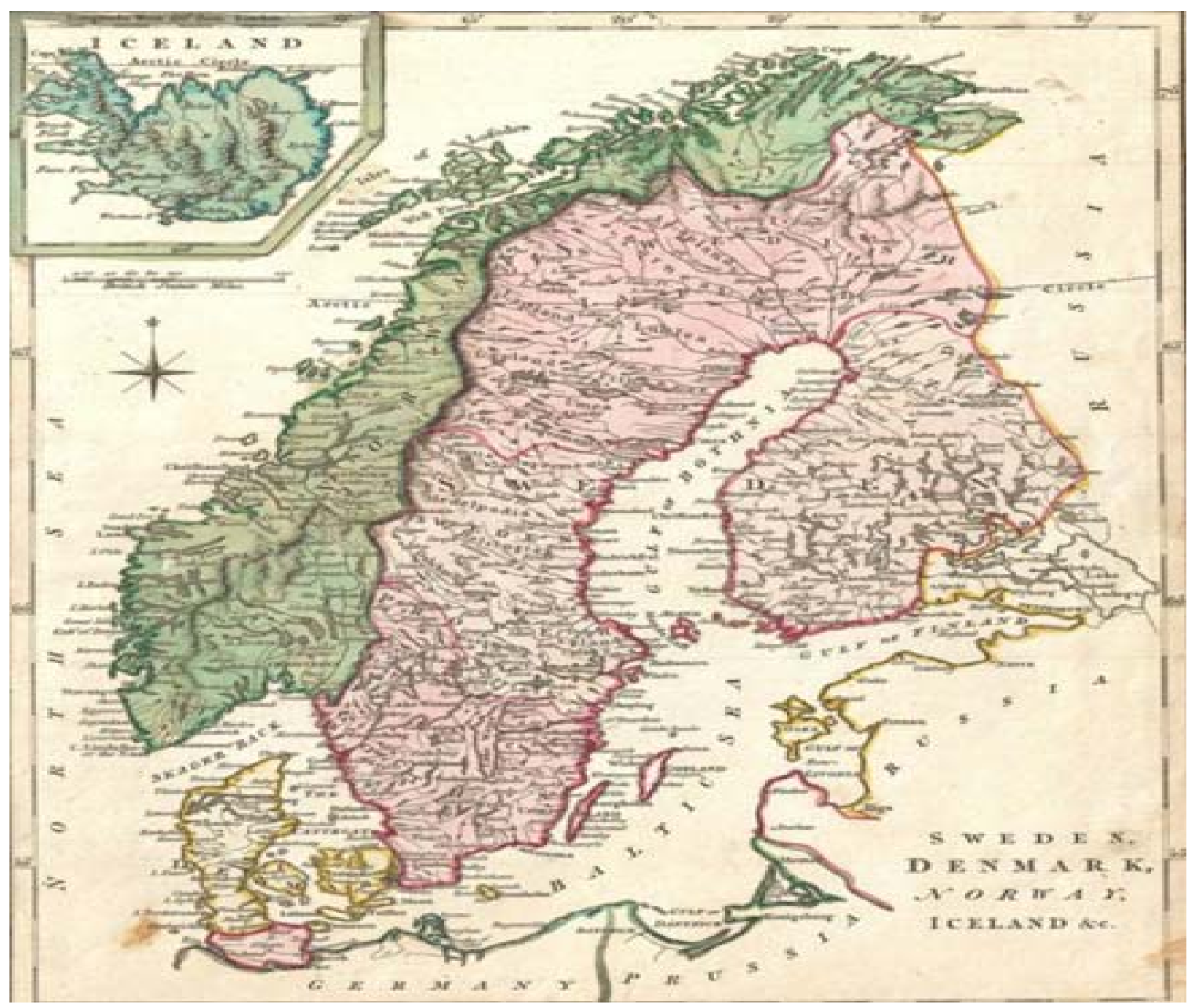

Power relations in Norden would remain colored by the 'two plus six' model, where Denmark and Sweden were the two powers, and the other three contemporary states (Iceland, Finland, and Norway) as well as the three autonomous home rule territories (Åland Islands, Faeroe Islands, and Greenland) until the middle of the twentieth century, when political integration equalized each state within institutions. The story of the Nordic peace, when viewed through this lens, becomes more remarkable for its ability to overcome deeply entrenched rivalries with centuries of history. The Nordic area is 
celebrated anecdotally, and studied empirically, because of this extraordinary feat. What follows is a concise narrative of how this unique region came to be.

Before the Peace: Norden before 1815

The Kingdom of Denmark is located at the northernmost extremities of the Jutland, a peninsular offshoot from modern Germany, and by extension, the European mainland. Composed of the Jutland and the 407-island Danish Archipelago on which its capital, Copenhagen sits-with a considerable amount of flat, arable land, Denmark has hosted human settlement since 12,500 BCE. Separated from its Nordic counterparts by the Baltic Sea and the Danish Strait, the bulk of its recorded history has been defined by its rivalry with its closest geographical neighbor: Sweden.

The history of peace in the Nordic area should be considered within a dynamic of 'imperial states' and 'successor states,' where the former dominant powers, Denmark and Sweden, fall into the former category and the ascendant Nordic states of Finland, Iceland, and Norway are categorized as the latter in the typology (Arter 1998: 1). Viewed through the prism of this dynamic, a bitter history of conquering, re-conquering, and rebellion becomes apparent. Until the very earliest days of the early twentieth century, peace in the Nordic region was far from guaranteed. As a function of this model of the Nordic area, regional relations were fraught with mistrust and frequent plays for greater power, usually through the taking, or re-taking, of some territory in or around the Baltic Sea, and to a lesser extent, in the far North Atlantic Ocean. Because of this dynamic, the Nordic peace has long been a phenomenon of great interest within peace studies. 
As was mentioned in the preceding section, the historical linkages of Viking heritage to Denmark are equally strong as they are to Norway and Sweden. ${ }^{14}$ The fundamental difference between these three types of Viking was the direction in which they left their homelands to pursue settlement further afield. Sweden's Vikings were most active eastward from their homelands; the Danish Vikings directed their attempts at colonization toward Western Europe and the British Isles, and the Norwegian Vikings set out toward Greenland, Iceland and the northernmost islands of the North Sea. Denmark was aggregated into its modern form and Christianized in the late tenth century CE. Exemplary of the power of the Danish Crown in the fourteenth century was its union with Norway in 1380-through which it also acquired territorial control of Iceland-and the subsequent formation of the Kalmar Union. This brought the Swedish and Finnish territories under control of Denmark and gave Queen Margaret I the power to direct the foreign and domestic policies of a territory spanning some 3 million square kilometers (Arter 1998: 1-2, 14). The Danish-orchestrated Kalmar Union entered into effect in 1397, firmly establishing Danish dominance of the region, and cementing its place as a European power. Under this arrangement, Denmark, Norway, and Sweden were unified as nominal equals, but Sweden's frequent attempts to break the union and Denmark's equally frequent re-conquering of its northeastern neighbor proved Denmark as the senior partner in the Kalmar Union.

The specifics of the Kalmar Union set important precedents for future dealings among the Nordic States and their territories, chief among them was a predilection for political

\footnotetext{
${ }^{14}$ The blanket term "Danes," is comonly understood to be interchangeable with Vikings in many historical accounts, including Arter 1998.
} 
agreements over territorial claims (e.g., the Treaty of Kalmar, which bound the three kingdoms of Denmark, Norway, and Sweden) (Arter 1998: 14-15). Interestingly, the Union gave the prime directive of foreign and domestic policy to the monarch (who on balance, tended to be a Dane); however, each of the three kingdoms retained a high degree of autonomy within this construct (Arter 1998: 14). It is also difficult to view the rotation of control from kingdom to kingdom during that period as anything but exceptional in light of the fact that power shifts from Denmark to Norway, and to Sweden and back again all occurred without negative effect for the Union. What brought about the end of the Kalmar Union were Swedish grievances over Danish attempts at conquest (Arter 1998: 15). The end of the Kalmar Union in 1523 would add significant layers to one of Denmark's enduring geostrategic rivalries, that with Sweden, for centuries to come.

The breakup of the Kalmar Union resulted in the continued personal union of DenmarkNorway, whose joint control remained in the hands of Danish monarchs until 1840 (Arter 1998: 15). Sweden charted its own course through those intervening centuries as an empire with a taste for expansion. Though occasional military attempts at reunification came and went without much success (with the last being the Kalmar War of 1611-1614), the energies of Scandinavia's monarchs turned to deepening the Protestant ReformationScandinavia is famously attached to Lutheranism-and, in Sweden's case, establishing itself as one of Europe's great powers (Arter 1998: 15). The Swedish Empire had, since the twelfth century, exercised control over the territories of modern-day Finland (Arter 1998: 13), or been engaged in conflict with the Rus people (whose namesake is lent to 
Russia) over its administration. After the breakup of the Kalmar Union, King Gustavus Adolphus began to prosecute campaigns for territorial expansion that would see the seizure of territories from the powerful Russian Empire (Arter 1998: 15-16). During Europe’s 30 Years War, the Swedes succeeded in annexing modern-day Estonia, Latvia, and areas of Lithuania, Poland and Northern Germany (Arter 1998: 15-16). Though those territories would help to build Sweden's profile as a great European power, the importance of the continuous domination of Finland by Sweden since the year 1150 until 1809 cannot be overlooked when one analyzes the region.

Finland, though not culturally Scandinavian, has long played an important role in the power politics of the Baltic region (referring to the states lining the Baltic Sea to Sweden's east; between it and present-day Estonia, Finland, Latvia, Lithuania, and Russia). The Swedes Christianized the Finns in the twelfth century CE, and in the succeeding centuries, the royals of Sweden would exercise control over Finnish territory while allowing for varying degrees of sovereignty among the Finnish people. The Great Northern War of 1700-1721 between the Russian Empire and that of the Swedes would mark the beginning of formalized Russian attempts at control of the Finnish territories. (Kujala 2000: 70) Sweden won the Great Northern War and retained control over Finland and the surrounding areas, but its status as a war zone over the course of two decades took its toll on Finland: famine, epidemics, and social discord meant that Finland lost half of its population during this period. (Kujala 2000: 74) It is at this historical juncture where the pacific nature of Finnish foreign relations, with particular regard to its neighbors, appears almost miraculous. In 1809, Russia removed Sweden's rule from the 
Finnish territories and established the autonomous Duchy of Finland. For the better part of a century, Finland enjoyed the peace of the Pax Russica, remaining vigilant and wary of the possibility of another Swedish takeover.

Map II.4: Post-Napoleonic Nordic Area

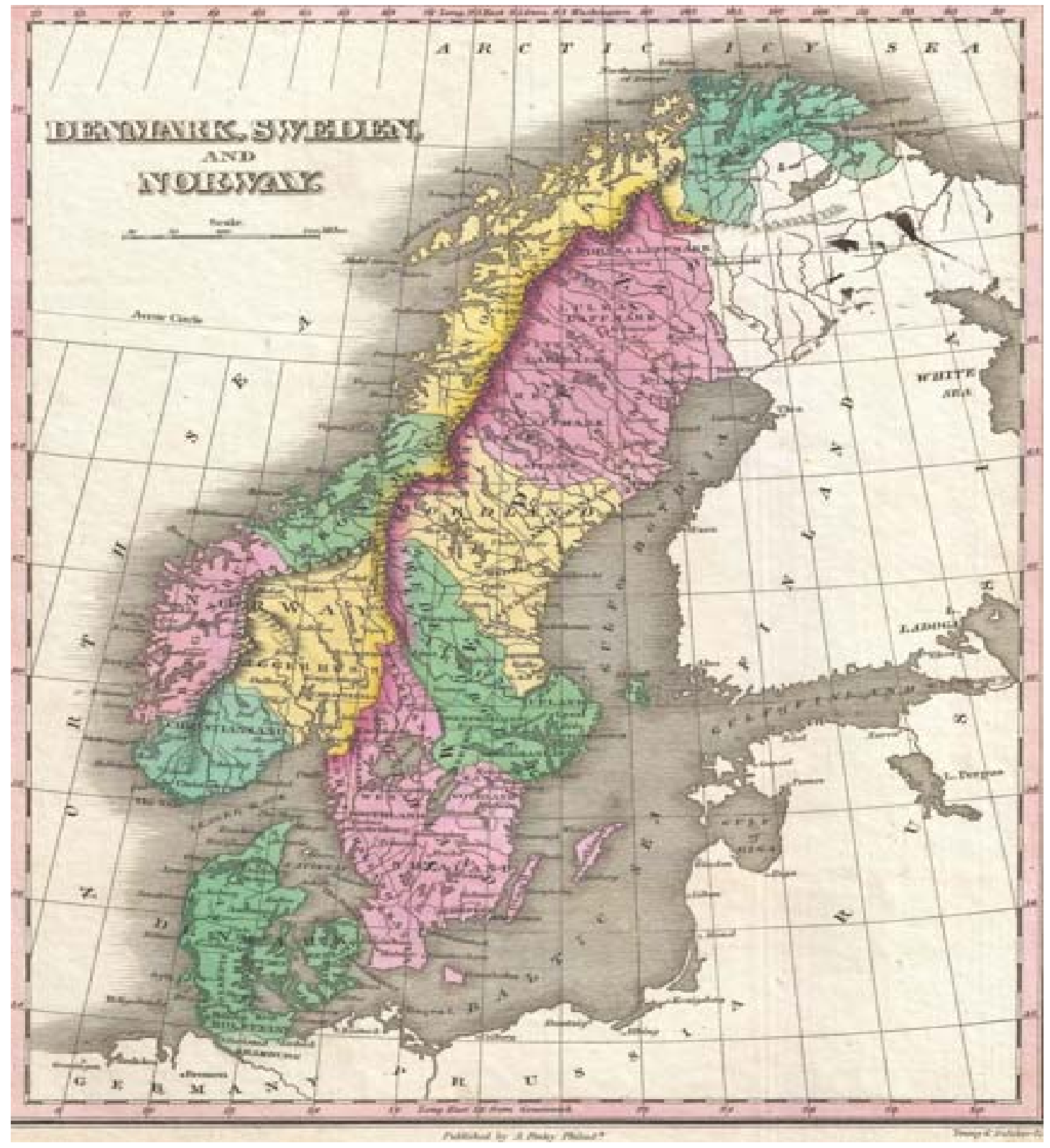




\section{Negative Peace: The Nordic Area after the Fall of Napoleon}

The Napoleonic Wars shaped modern Scandinavia in another critical way: though Sweden was pressed to cede the Finnish territories that it controlled to Russia, its elected crown prince and king leveraged their connections to other European powersspecifically, Germany and Russia-to pressure King Frederik VI of Denmark into giving control of Norway over to its Baltic neighbor (Arter 1998: 17). The Kingdom of Norway had been subsidiary to that of Denmark in a personal union that formed the political entity known as Denmark-Norway (alternately referred to as the Kingdom of Denmark) from 1542-1814 (National Archives 2005b). The brief war that Sweden prosecuted to take control of Norway was a relatively minor one, but it also marked the last interstate military conflict within the Nordic area (National Archives 2005a). The Swedish campaign ended after a little more than two weeks in an uneasy ceasefire, but also with the guarantee that Norway's constitution would be respected by the new arrangement (National Archives 2005b). The tensions over the next 90 years generally centered on differences of opinion concerning the closeness of the union, rather than its existence. The outside rule of one country by another is a situation that time and again has produced violence, but it was managed quite peacefully in the Nordic case. Norway introduced its own parliament in 1884, which heightened tensions with Sweden and threatened the Swedish sovereign's ability to dictate foreign policy within the union, but political conflict never devolved into violent conclusions between the two kingdoms (National Archives 2005b). 
Although Denmark lost control of Norway to Sweden in 1814, it held territories elsewhere that would prove problematic over the following centuries. On its southern border, the struggle to retain control over an ethnically German region of then-Prussia, Schleswig-Holstein, would prove the most taxing of its remaining imperial pursuits. The mid-nineteenth century was eventful for Denmark on two fronts: the peaceful adoption of a constitutional monarchy (1849), and the last two wars Denmark prosecuted, the First (1848-51) and Second (1864) Schleswig-Holstein Wars. Denmark’s modern history is marked by a precipitous decline in violent international relations, establishing a clear preference for peace. The conclusion of the Second Schleswig-Holstein War in 1864 left a deep impression on the Danish. Traumatized by Europe’s Great War, the wary Danish leadership chose not to accept the return of their lost territory without the affirmation of a plebiscite. The Danish were offered the return of the Schleswig-Holstein territory after the dismantling of the German Empire, but war-wary leadership chose the option that would ensure peace, and Schleswig remains a province of Denmark today.

Finland's domination at the hands of the Swedish remained uninterrupted until 1808, at which point the Napoleonic Wars in Europe had affected the territorial landscapes of the Baltic region and the last Russo-Swedish War was fought for control of Finland-then the eastern third of Sweden’s national territory (Arter 1998: 17). Russia’s successful defenses against the United Kingdom gave it leverage in its demands for Finnish territories, and in 1809, having successfully vanquished the Swedes, the Russians secured the transfer of the Grand Duchy of Finland to the control of the Russian Empire (Arter 1998: 17). Though Finland remained autonomous under this arrangement, he importance of Russian 
dominance in the region would change the course of relations among the Nordic states over the next 150 years and establish a precedent of wars against Russia (Archer 1996: 458). Finnish independence movements gained significant momentum in the latter half of the nineteenth century with aims to establish an independent and sovereign Finland-a feat which would not be accomplished in earnest until 1919 (Arter 1998: 27, 30). The conclusion of the Finnish Civil War in 1917 resulted in the Finnish Parliament deciding to join Imperial Germany, but the subsequent conclusion of World War I and the Treaty of Versailles obviated the German Empire (Arter 1998: 29). Thus, the Finns established a presidential republic, but its ties with Soviet Russia remained tense and, at times, violent, until a final agreement on Finnish sovereignty was recognized by the Soviets in 1948 that respected territorial boundaries and Finnish neutrality (Arter 1998: 254).

In 1902, the Norwegian clamor for its own consular services resurfaced as an issue that threatened the integrity of the Swedish-controlled union between the two countries. Norway pursued a path of negotiation with Sweden that resolved itself in 1905's peaceful dissolution of the union between these Nordic neighbors (Archives 2005b). 1905 was a seminal year for the Nordics in many important respects, not the least of which was the fact that Sweden's king faced a choice of going to war to retain its dominion. Beyond Sweden's non-aggression towards Norway, another important step in Nordic governance was the fact that the Norwegians voted to reinstate their monarchy, and elected a Danish royal to serve as the figurehead of the country's government. Since 1905, with the exception of World War II, Norway has been at total peace. Sweden and Norway have since maintained close and amicable relations, and each of them represent key players in 
the most peaceful sub-region in the world. To summarize, Norway's role in the dynamics of the Nordic region is often ambiguous when viewed through the microscope of history. Its oscillation from mid-major power to territorial holding makes its non-violent disposition difficult to grasp.

The twentieth century brought many opportunities for armed conflict to the Nordic area, yet unlike nearly every other region in the world, the leadership in each state chose to resolve disputes without violence. As acrimony built up in Norway after Sweden's campaign to reclaim it as a subordinate territory in 1814, the stage was set for violent conflict between the two old rival states in 1905. That year, Norway's parliament, the Storting, had resolved to end the Swedish-dominated personal union of the postNapoleonic Wars decades of the nineteenth century. The three centuries between the dissolution of the Kalmar Union and the end of the Napoleonic were typified by fighting over Norwegian territory, and the 1905 dissolution of the Sweden-Norway Union would prove to be perhaps the ultimate test over whether the two central territories in Norden would continue on a peaceful, if somewhat bitter, path or whether Sweden's monarch would again respond to unilateral moves toward independence with violence.

The war to re-conquer Norway in 1905 never came. Sweden's king, though insulted by this move, ultimately opted to accede the territory to Norway, in what is now viewed through the lens of history as a major first step toward institutionalizing preferences for peaceful resolution of disputes-no matter how great the stakes. Håkan Wiberg claims this major event in Nordic history as the first non-war, and an important precedent in the path toward deeper peace (1990: 15, via Archer and Joenniemi 2003: 5). World War I came 
and went without incident among the Nordic states, with the neutrality of the three major territories (Denmark, Norway, and Sweden) all receiving respect from the warring parties. Interestingly, the participants at Versailles offered to redraw the lost SchleswigHolstein territories into Denmark after Prussia’s dissolution. The Danes refused to accept this cession without plebiscites (fearing irredentism), but at the conclusion of the two votes on Danish citizenship for the citizens of Schleswig and Holstein, Northern Schleswig elected to re-unify with Denmark.

Denmark's reunification process with Schleswig, although peaceful, also provided perhaps the most serious test to Denmark's constitutional monarchy system. The Easter Crisis of 1920 resulted in a rebalancing of the relationship between Denmark's monarchy and its parliament. As a result of dissatisfaction with the terms of Schleswig's reunification with Denmark, King Christian X insisted that the Danish parliament include an area of Schleswig in which no plebiscite had been conducted in its plans for reabsorbing territory. When Prime Minister Carl Zahle refused this request, Christian X dissolved parliament, leading to widespread protests. After realizing a potential overthrow of the Danish crown as a realistic scenario, Christian X moderated his position and dismissed the replacement government. From that point in history, the Danish monarchy has accepted a severely reduced role in governing Denmark.

The inter-war period also brought about new opportunities for violent conflict resolution in the Nordic region. Sweden's dispute with Finland over the Åland Islands and Norway's dispute with Denmark over possession of East Greenland were both resolved peacefully through diplomatic machinations. Each of those incidents would add to the 
catalog of territorial disputes that the involved parties chose to resolve diplomatically, further cementing a norm of non-aggression among the Nordic region’s leaders.

World War II was considerably more turbulent for the Nordic countries. Iceland was subjugated by a British invasion in 1940 because of its strategic position as a bulwark to German gains in Northern Europe. Norway and Denmark were occupied by Nazi Germany while Finland seized the opportunity to add a party in its recurrent native campaigns to throw off the Russian yoke (at this point the Soviet Union) and became a German co-belligerent. Though none of the above-mentioned states entered into violent conflict with another, the closing years of the Second World War provided yet another major test for the Nordic peace.

\section{A Stable Peace in the Nordic Region: 1929 to 1948}

The precursor to the Nordic Council, the Nordic Association, was founded in Denmark, Sweden, and Norway in 1917, and by 1924 had grown to encompass Finland and Iceland (Hoydal). It was not until the 1930s however that the partnership produced any binding results, but it signaled the beginnings of a programmatic relationship based on mutual trust. Crucially, it was around this time also that Sweden and Norway had officially stopped planning for war against each other. At the same time, the formerly stalwart royalist conservatives in Swedish parliament were also fully supporting electoral reform that deepened democratic reforms in what was perhaps the Nordic area's last holdout state in terms of accepting and implementing a political democracy (Ericson 2003: 4041). 
Map II.5: The Nordic Area in the Inter-War Period (1926)

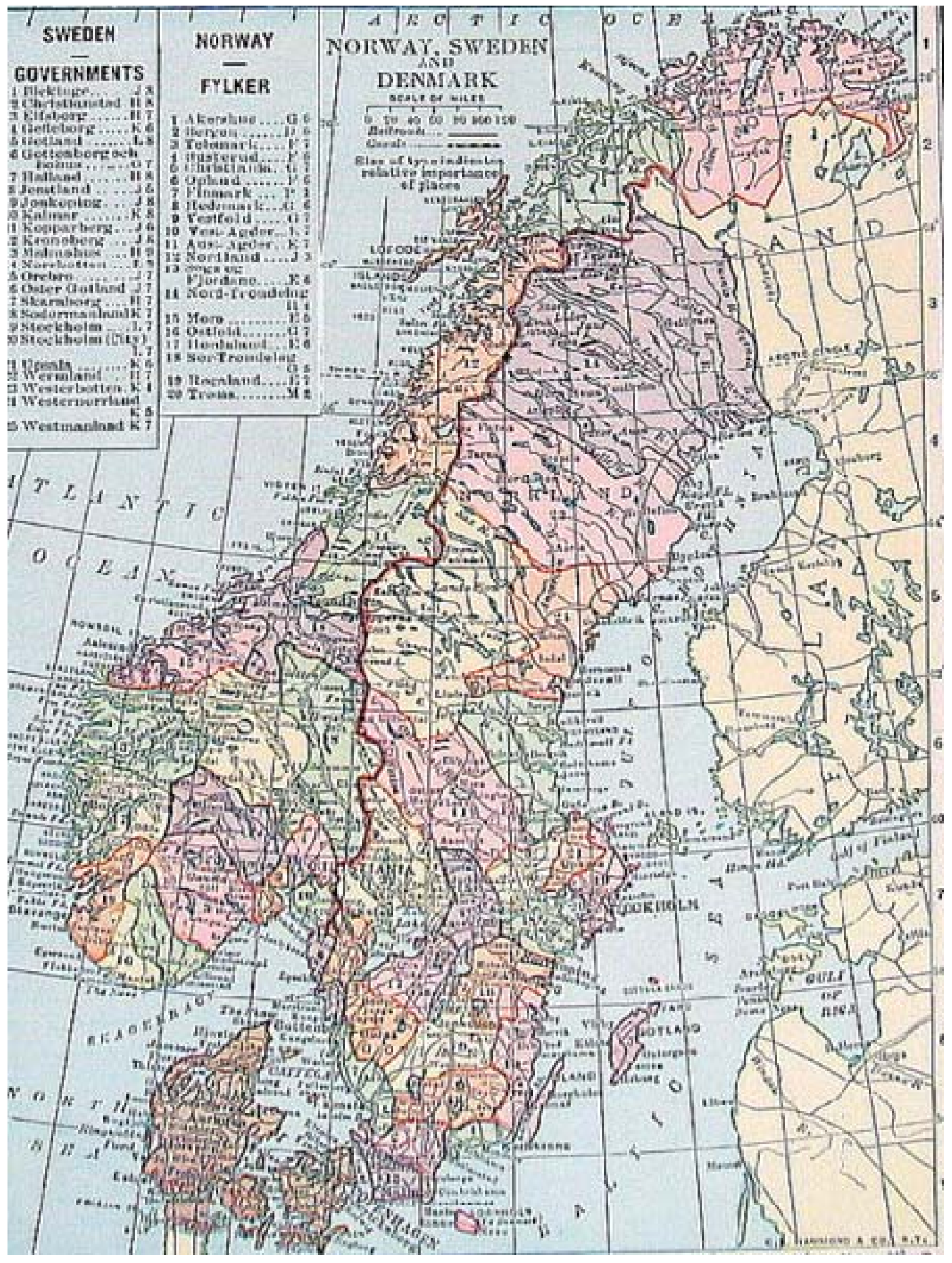


This period of peaceful stability can also be characterized by a series of important issues being resolved in a systematic and peaceful manner. Among these issues was the dispute between Norway and Denmark over 100,000 square miles of East Greenland. Both parties assented to Hague arbitration, and when the decision was handed down, Denmark was awarded the whole of the territory (Wiberg 2003: 3). Norway's response was nonviolent and good relations with Denmark resumed immediately. After the Second World War had concluded, the Faroese set up a referendum on independence from Denmark. Although a small majority voted to declare independence, Denmark negotiated a settlement for greater Faroese autonomy in exchange for continued Danish administration (Wiberg 2003: 3). The deal was agreed to and the arrangement made in 1946 remains largely unchanged today. In each instance, major disputes deeply rooted in cultural tradition were successfully pursued through judicial and diplomatic means, as opposed to militating against an adversary.

The identification of a common threat was another major unifying factor that helped to move the region closer to a stable peace among its states. The Soviet invasion of Finland and the Nazi invasion of Denmark and Norway in 1940 provoked a unified voice of consternation for the circumstances and a call for support of the occupied peoples. (Sweden remained neutral during World War II) Certainly, World War II was a trying time for the Nordic countries involved in it, however the large-scale violence of the war remained, purely defensive within Nordic territories; thus, not disqualifying in a zones of peace analysis. The common expression of support however might be more telling about the quality of peace experienced in the Nordic states during those times. 
Another seminal event during this time was also indicative that a stable peace had developed in the Nordic area. Iceland, still a territory of Denmark in 1944, elected to move from home rule to full independence and eschewed the long-ruling Danish monarchy. Although Iceland had not seen war on its soil since the 1300s, the move to independence provided what might have been the most likely circumstances for it since. The personal union between Denmark and Iceland agreed to in 1918 was valid for 25 years, and at the end of its cycle, Icelanders voted overwhelmingly to (1) dissolve the union with Denmark; and (2) adopt a republican constitution. Even though Denmark's economic and military asymmetries relative to Iceland would suggest a high probability of success were Denmark to wage war; the costs, both human and financial, would have certainly been daunting. Additionally, the fact that occupying Germany loomed over the monarchy's decision-making capabilities, made such decisions even less likely. The Icelandic parliament had already resolved that Christian $\mathrm{X}$ was unable to perform his duties as a governor of the island during Denmark's occupation in 1940. The advent of full independence in Iceland passed without incident, and Nordic leadership seized another non-war opportunity.

Security Community in the Nordic Area: 1948 to the Present

The advent of the North Atlantic Treaty Organization (NATO) immediately following the conclusion of World War II lent some ambiguity to the security picture among the Nordics, but the Nordic Council provided an outlet for cooperation on a broad swath of issues between each of the region's five states. Disputes among Nordic states in the decades following World War II arose largely over fisheries. Disputes with Russia and 
Britain concerning economic exclusivity of fishing waters were relatively frequent, and although none came to a large-scale, violent head, coast guard ships and formal diplomatic complaints were used on numerous occasions. Fisheries constitute a large part of each country's gross domestic product. In every case, the countries in question uniformly resolved these high stakes disputes through diplomacy, though some more quickly and decisively than others. For example: Iceland's sporadic disputes with Britain spanned over three decades and Norway remained at a loggerheads with the Soviet Union, and later Russia, over the 'Grey Zone' (a territorially ambiguous 175,000 square kilometer section of the Barents Sea) for 44 years, having only agreed on usage rights in 2010.

The end of violence in Denmark is doubly surprising, on the global scale, given its vast territorial claims over other nations. Denmark's territorial control extends to this day to the island of Greenland, but its former holdings include a large swath of England (during the early middle ages), colonial holdings in India, the Caribbean, and West Africa, Norway (which will be discussed at length in succeeding pages), and the nowindependent Iceland. (Arter 1998: 13-16) The former Danish mandate of Iceland has a troubled history with the Danish Crown, but that history never bred violent conflict, and understanding Iceland can be difficult when viewed through the lens of violence. Before World War II, Iceland's last wars occurred in the late thirteenth century, making their journey towards independence from Norway, and then Denmark, entirely peaceful. Iceland's lack of violent conflict in its history is often attributed to three main factors: its cultural similarities with the other Scandinavian states, its relative isolation, and its 
diminutive population. (Arter 1998: 36-37) Independence movements arose in the nineteenth century, but the call for violence against the Danish was always muted and never became a prominent theme. (Arter 1998: 36-37) One would imagine that if for no other reason, the logistics of fighting a war and arming a defense force would be difficult if not impossible given the time period and Iceland's geographical disadvantages (Denmark is connected to Continental Europe). This dynamic will be discussed in greater detail in the next section.

Table II.1: Years of Independence and Democracy for Each Nordic State

\begin{tabular}{|l|l|l|}
\hline Country & Year of Fully & Year Democratic Processes Began \\
\hline Denmark & N/A & \\
\hline Iceland & 1944 (Denmark) & 930 \\
\hline Finland & 1918 (Soviet Union) & 1919 \\
\hline Norway & 1905 (Sweden) & 1814 \\
\hline Sweden & N/A & 1809 \\
\hline
\end{tabular}

In light of the historical record, does the Nordic area qualify as a zone of peace? There appears to be sufficient prima facie evidence to lend credibility to such a claim, and that the Nordic area has passed through Kacowicz's gradations toward a Deutschian security community, but more detail is necessary to confirm this assumption. 
Table II.2: Years of Last Violent Confrontations for Each Nordic State

\begin{tabular}{|l|l|l|}
\hline Country & Year of last Violent Confrontation & Year of last Violent Confrontation \\
\hline with Intraregional Powers & with Extraregional Powers \\
\hline Denmark & 1813 (Sweden) & (opposition) \\
\hline Iceland & $1262 / 4$ (Norway) & 1864 (German Confederation) \\
\hline Finland & Inconclusive. $^{15}$ Likely 1250 & 1945 (Nazi Germany) \\
\hline Norway & (Sweden) & 1945 (Nazi Germany) \\
\hline Sweden & 1814 (Norway) & 1814 (French Empire) \\
\hline
\end{tabular}

A negative zone of peace meets two stipulations: (1) There can be no (or very little) intraregional, inter-state war; and (2) there exists little to no war between the region's states and extraregional states-that which does exist, must be initiated by other states. As violence between the Nordic states ceased before 1814's end, the Nordic area easily clears the first threshold, though there is a caveat. Any Finnish involvement in wars between 1250 and 1917 happened by proxy. Nevertheless, in light of the historical record, Finland's involvement in wars within the region was scant.

The Nordic area also meets the second requirement (that its states eschew war with extraregional states), but it does so with less clarity. It would be difficult to dispute that

\footnotetext{
${ }^{15}$ Between 1250 and 1809, Finland was a territory of Sweden. Between 1809 and 1918, it was an autonomous duchy of the Russian Empire. Sovereign decisions to participate in war are difficult to assess.
} 
the Nordic states have been limited in their choices to prosecute extraregional conflicts since 1814, but at first glance, Finland's violent twentieth century appears to disqualify the region in toto. The important addendum to the second stipulation of a negative zone of peace is that what aggression does occur between the region's states and extraregional ones must be defensive in nature. With that stipulation considered in whole, the Nordic area has very little trouble clearing the bar of negative peace. When one considers limited extraregional aggression with no defensive purpose at the forefront of the causus belli, surely Denmark’s Schlewsig-Holstein Wars $(1848-51,1864)$ stand alone, while Iceland, Finland, Norway, and Sweden claim none since the advent of negative peace. Thus, it is clear that when considering intent (offensive versus defensive) that the Nordic region has sufficiently avoided violent conflict with extraregional actors and fully qualifies as, at minimum, a negative zone of peace.

What of stable peace in the Nordic area? At what point, if any, did the Nordic area become a stable zone of peace? To achieve such a designation, two additional requirements must be met: (3) Little to no civil war or domestic conflict (in the form of armed uprisings) can take place within a stable zone of peace; and (4) Military intervention by any of the region's states in another part of the world (without being part of an internationally sanctioned mission) is extremely limited or non-existent in a stable zone of peace. The former stipulation is one of the most elucidating aspects of the Nordic peace: its leaders have routinely opted for 'non-wars' (Wiberg 1990, via Archer and Joenniemi: 5) in the face of antagonistic independence movements. Certainly, even today, such a response to irredentism or independence claims is exceedingly rare. 
As a region dominated by two powers, Denmark and Sweden, for the bulk of its history holding sway over several 'colonies' in Greenland, Iceland, the Faeroe Islands, Finland, and Norway, the lack of violence as the three most populous of those colonies achieved independence is remarkable. To that end, civil war, or violent uprisings of any kind, are exceedingly rare in Norden's regional history. Finland's wars for independence were not only unique in the region's modern history, but their civil war was aimed at removing the yoke of the newly formed Soviet Union or Nazi occupiers from their land. It would likely be difficult to characterize the Finnish Civil War (1918) as a war between a people and its once-legitimate government. Thus, regardless of Finland's contribution to the region's history of domestic conflict, the occurrence of true civil war in the Nordic area is, at most, minimal.

Military intervention by the region's states in other areas of the world is also sufficiently limited to be included within stable zone of peace credentials. Denmark again might be viewed as the region's most prolific extraregional aggressor, although malicious intent (that is, to install a friendly government in far flung lands, etc.) is generally imperceptible. Denmark contributed to the Estonian War of Independence waged against the Soviet Union (1918-1920) and the Winter War (1939-1940) between Finland and, again, the Soviet Union. Post-occupation Denmark also contributed to the efforts of the Korean War alongside the United States and South Korea (1950-1953). Since then, like its regional counterparts, Denmark's interventions in other parts of the world have been limited to participation in broad NATO or United Nations (UN) coalitions. It should be noted that resistance among the peoples of the Nordic area to joining even the broadest of 
coalition interventions abroad is considerable. There are many prominent policy makers and scholars throughout the Nordic region who oppose such choices, and Nordic participation in military intervention can generally be characterized as reluctant.

Having established the Nordic zone of peace as duly qualified for the mantel of stable peace, the question of whether the region qualifies as a security community follows logically. As Norden occupies a unique position in peace studies as paradigmatic for regional peace, the discussion of whether its states comprise a security community is abundant and well covered within international relations literature. There are many who argue that the Nordic area constitutes the truest embodiment of a Deutschian security community, or that it has come closest in a world where no region meets such standards. With that, the final two stipulations for progression from a zone for stable peace to a security community are as follows: (5) None of the region's states have any realistic expectation of the first four stipulations; and (6) The region's states share in political institutions and democracy, and are prolifically interdependent. These two tenets of security community have borne significant fruit in debates over the modern role of Deutsch’s most famous contribution to security studies.

When thought of in the contemporary context, it would be difficult to imagine any of the Nordic states committing to any major policy shifts towards a war footing, with its neighbors or any other country. Indeed, in a region that has not seen war of any kind since the first half of the twentieth century, ideations of war being prosecuted from the Nordics seem far-fetched. Similarly, the likelihood for any shift to a militarily active, interventionist foreign policy is extremely low, as preference structures (which will be 
discussed in the next section at greater length) in the Nordics bind leaders to espousing a pacific worldview by acting as a barrier to election. Finally among the first four zones of peace tenets, the likelihood of armed domestic conflict in the Nordic area also appears exceedingly low. It bears mentioning that the Nordic countries deal well with their small, but historically important, ethnic minorities and extraterritorial holdings. As evidence, the Sami (the most prominent ethnic minority) elected their own parliament without incident in the late 1990s, and the questions of the Åland Islands and Greenland were settled diplomatically, despite the tense nature of their disputes. It seems that the most prominent drivers of civil conflict (lack of ethnic representation in government or autonomy) have been sufficiently minimized within the Nordic area.

Regarding the final step to security community-political institutions, democracy, and interdependence-the record is uneven in some respects. Although each Nordic state counts among the world's most developed pluralist democracies, and all share parliamentary configurations (though, in some cases with the addition of a monarch whose role ranges from purely ceremonial to weakly endowed in the political arena), the Nordic experience with integration is less clear. Perhaps the most important symbol of integration, and the embodiment of the Nordic regional identity, is the Nordic Council. Binding all five Nordic countries to a relatively broad integration agenda since 1952, the Nordic Council represents the launching point of the Nordic common market and customs union. Though politically and economically highly interdependent within their own region, security cooperation in Norden remains sporadic and reluctant and similar types of integration with Europe remain highly uneven. NATO membership represents an 
odd geopolitical history in the region, reflective of its sensitive strategic position during the Cold War, and only three of the Nordics are current members of the trans-Atlantic security partnership (Denmark, Iceland, and Norway). While Sweden maintains military neutrality, Finland's non-accession to NATO is tinged (if not wholly determined) by its pragmatic need for peace on its eastern border.

Security is an explicit part of the term security community, but a relative lack of coordination and focus on the matter remains a bit puzzling. Even if the security aspect of integration within the region is lacking, Adler and Barnett do not find such undeveloped ties disqualifying, as the regional balance has developed into "a reciprocity that expresses some degree of long-term interest and perhaps even altruism” (1998: 31). According to the leading scholars on the Nordic area, the expectation of being militated against within the region is so infinitesimally small that the need for a greater focus on security cooperation is now moot.

Having established the Nordic area as a zone of peace after reviewing its history as a peaceful region and discussing its relationship to the tenets of the three gradations of zones of peace, this study moves directly into the discussion of why this is so. The following section asks, and answers, two distinct but related questions. Why is the Nordic region peaceful, particularly in spite of centuries-long rivalry dominating the region's history? Second, what factors allow for the continued endurance, and attendant maturation, of the Nordic zone of peace? 


\section{Explaining the Nordic Zone of Peace}

This section seeks to bring the most prominent, agreed-upon determining variables in the Nordic peace. That the long peace in the Nordic area constitutes the world's most pacific region is a phenomenon that has attracted considerable debate over a) its roots; and b) what allows it to continue. After consulting a great deal of scholarship on the Nordic peace, this research focuses on the most-circulated and least contested causes, and also adds an assessment of the applicability of one more broad, overarching generalization about zones of peace. Following is a discussion of those factors relative to the historical narrative compiled previously (as detailed in Archer and Joenniemi 2003), as well as the one universal assumption about maintaining a zone of peace.

\section{Factor 1: Geostrategic Location}

Is the Nordic area's location an asset in maintaining peace? Due to its extreme geographical position within Europe (earning it the distinction as 'the quiet corner of Europe') and globally, do its territories get overlooked in strategic calculi? Put more bluntly, does the Nordic area 'matter' to the war plans of the world's great powers? There is some research that suggests that the Nordic zone of peace is maintained, at least partially, by virtue of its location, and that its relative remoteness and foreboding internal geography (and thereby climate) lessens opportunity for violent conflict, both within the Nordic area and without.

Håkan Wiberg offers evidence to support the strategic position hypothesis (1993). In his view, the territorial losses affected by the Napoleonic wars lessened conflict opportunities between the affected states and their longtime 'colonial' rulers, as control of Finland and 
Norway changed hands. Wiberg asserts that Finland being wrested from more than five centuries of Swedish control and ceded to Russia in 1809, and control of Norway moving from the Danish monarchy to the Swedish in 1814, allowed for both countries to achieve independence more easily (1993: 210, 212). The Finnish example casts some doubt on his claim, but Wiberg adds evidence by noting that no great powers came to the aid of Sweden after Norway dissolved its union with Stockholm in 1905. Certainly there is ample evidence in the historical record that verifies this assertion. Similarly, the Nordic area was largely free of involvement in World War I; and although the Finnish wars for independence began as a result of the Bolshevik overthrow of the Russian Empire, neither country was at that point involved in the remaining hostilities of Europe's Great War. In World War II however, the strategic importance of Norway was clear to Churchill, Stalin, and Hitler (Archer and Joenniemi 2003: 9). As a result, Germany occupied Norway mainly for access to warm water ports to transport Swedish iron ore in support of its war effort. Beyond this however, the Nordic area was largely peripheral to the broader war on the European continent.

The Cold War appears to have been an exception to this clause of Nordic peace. It would be difficult to argue that the Nordic states were important fronts on the order of the thendivided Germany, but Iceland and Finland both played significant roles in the strategic balancing between the two dominant superpowers. To wit, Iceland's entry into NATO in 1952 provoked protests in the island country as its leaders were coerced into the organization by the United States. The United States saw the Arctic path as the quickest and most vulnerable path to attack by the Soviets, and pressured Iceland into joining the 
organization so that it could maintain air bases critical to early warning of incoming flights or missile detection (Solheim 1994: 9). On the other hand, Norden's uneven participation in NATO is also indicative of the strategic importance of the region. Given Finland's history with Russia and its long, direct border with its Eastern neighbor, the Soviets were determined not to risk Finnish accession to the transatlantic alliance. The potential threat to the Soviets was obvious, and thus, Moscow agreed to stall its attempts to retake Finland on the condition that NATO membership was not forthcoming. (Norway's border with Russia is well above the Arctic Circle, adding significant logistical challenges to any plans for war, and neither Denmark nor Sweden shares a border with Russia.)

In relative terms, it is certainly clear that the Nordic area's remoteness did buffer it from large-scale conflict of the magnitude that France, the Low Countries, or Poland were subject to during the last two centuries. Contrarily, the Nordic region’s import as a flank in both World War II and the Cold War should not be dismissed. To be sure, the Nordic area earned its status as the quiet corner of Europe, however, as Clive Archer surmises, this is not solely due to its geographical remoteness or a lack of strategic importance (Archer and Joenniemi 2003: 10). The strategic position of the Nordic states did indeed free it from conflict by limiting opportunities for it, but this does not suggest that its leaders were, or are, left without the choice to engage in violent conflict.

\section{Factor 2: Preferences of the Political Class}

Opportunities for conflict in the Nordic area were, and remain, rare, but they do exist. Do policy makers in the Nordic states choose to avoid conflict? If so, what leads them to do 
so? This section aims to add texture to the exiting analysis that posits that the Nordic states have largely avoided conflict outside of repelling extraregional powers from their own territories.

Perhaps the most obvious example of peace as a policy choice is Sweden's longstanding practice of neutrality. Effectively in force since the 1820s, Sweden's espousal of neutrality successfully managed to avoid wars that the rest of Europe had considerable difficulty avoiding. All of the independent Nordic countries chose to avoid involvement in World War I (Finland was an autonomous duchy of Russia at the onset of war), but World War II proved a greater test of the Nordic resolve to eschew violence. While Denmark, Finland, and Norway all struggled mightily with Nazi occupation during the Second World War, Sweden managed to avoid hostilities entirely. As noted by Clive Archer, the choice by Sweden's king to assist Denmark in its campaign to reclaim Schleswig and Holstein was rebuffed and subsequently halted by Swedish decisionmakers (Archer and Joenniemi 2003: 12). This behavior is symbolic of what Kupchan (2010a,b) terms institutionalized restraint, and is a necessary condition for the occurrence of stable peace; broadly applied, this principle contributes heavily to the establishment of a stable zone of peace.

The prominent example of Norway's unilateral dissolution of its union with Sweden in 1905 again comes to the fore. Magnus Ericson attributes the assessment of an increasingly powerful Swedish parliament that the Norwegian cause was not a worthwhile endeavor (2003). The decision not to reclaim Norway flew in the face of the wishes of the most elite conservatives in Sweden's parliament, as well as its king and its 
military, which, Ericson notes, continued to draft aggressive plans to retake Norway until 1917 (2003: 33). History points to a leveling off of economic and military asymmetries between Norway and Sweden in the 90 years since the last war between the two, but the importance of policy makers preferring peace should not be overlooked.

Sweden continued to set the tone in opting for a peaceful resolution to its claim to the Åland Islands between 1919 and 1921. Situated in the Gulf of Bothnia between Finland and Sweden, the Ålands could have been reclaimed by Sweden (as its inhabitants were pressing it to do), ostensibly with little threat of interference from outside powers on behalf of the newly independent Finland (Archer and Joenniemi: 12). Sweden's leaders however opted for a League of Nations brokered solution to the matter that arbitrated in favor of Finnish retention of the islands. Around the same time, the Danes, having learned the lessons of war, insisted on referenda to decide the future affiliations of the Schleswig-Holstein provinces. After the disaster of its last campaign to maintain sway over the area in 1864, Danish leaders were insistent upon a peaceful resolution when the matter returned to its parliamentary agenda in the years following World War I. The early 1930s brought yet another test of policy makers' will for war with the dispute between Denmark and Norway over East Greenland. Norwegian economic interests in the territory were important to its leaders, however policy makers in both countries opted to adhere to a judicial settlement instead of war.

In summation, it is clear that the preference structures of Nordic policy makers routinely preferred peace to even when military victory was all but certain. Surprisingly, attachments to territorial 'traditions' rarely outweighed a preference for peace after the 
Napoleonic Wars ended in the early nineteenth century, and Nordic leaders frequently absorbed 'losses' in the short term to preserve peace in the long run. World War II proved a total avoidance by policy makers to be impossible, however, that certainly looks to be an aberration rather than the norm in the Nordic area, giving hope that there might be discernible patterns to peace that the region can demonstrate for other regions where peace may not yet exist. In the Nordic case, it appears clear that there is a preference for lowering tensions and avoiding conflict that contributed heavily to the region's lasting peace.

\section{Factor 3: Political Culture}

Related to the preference structures of policy makers is the important facet of any regime: its political culture. As Clive Archer refers to Nordic leaders, they "are constrained by international events, but they are also products of prevailing culture within the Nordic societies.” (Archer and Joenniemi 2003: 14) The preferences of the peoples in the Nordic region eventually came to be reflected in the institutions and political behaviors they share with the international system.

Archer notes that the proponents of this explanation for the lasting Nordic peace generally claim that as the nineteenth century wound down the beginnings of a broadlyheld cultural value of social peace came to prominence in the Nordics (Archer and Joenniemi 2003: 14). This process accelerated rapidly in 1930 throughout the three major Scandinavian states (Denmark, Norway, and Sweden), and was later visible in Finland, presumably after freeing itself from concerns of communist intervention. (Archer 1996: 462) This attitude came to dominate diplomatic interactions between the Nordic states, 
particularly those with whom relations had been contentious in the past (Archer and Joenniemi 2003: 14). The second corollary posited by proponents of the political culture argument is defined by familial structures and sentiments in each state's indigenous political structures. (Archer and Joenniemi 2003: 14) To that end, this sense of family has largely served to restrain potential aggression by Nordic policy makers.

To be sure, it is difficult to identify the depth of familial behavior within the context of the historical narrative described in the preceding pages, though many venerable scholars on the Nordic peace have pointed to a value set, particularly in the political arena, within the Nordic area that emphasizes consensus, particularly in the political arena, social democracy, and a proclivity toward emphasizing Nordic cultural roots (see Elder, Thomas, and Arter 1982; Solheim 1993; Arter 1998). The Nordic Council, in many ways, serves as an embodiment of all three. Its establishment of a Nordic system for migration and work emphasizes the regional affinity for its own culture, or at least that its people are prioritized before other Europeans or non-Europeans. Similarly, the common institutions throughout the Nordic states under the auspices of the Nordic Council further demonstrate the premium placed on political consensus and conflict resolution, as well as a devotion to a uniquely Nordic political and social system.

As a matter of course, it seems, the behaviors and value systems described here have influenced the plying of foreign policy for all the states in the region. Where possible, the region's leaders stayed accountable to a broad societal sentiment of solidarity and preference for peace, and nowhere more so than within the Nordic zone of peace. Shared institutional and societal perspectives doubtless increased the comfort of Nordic leaders 
when dealing with their regional counterparts (Starr 1992: 210-211). In combination with preference structures for peace and relatively limited opportunities for conflict based on geography, understanding the Nordic political culture helps to paint a clearer picture of the zone of pace maintenance matrix among the Nordic states since the early 1800s.

\section{Factor 4: Interdependence and Political Institutions, Security Community}

Building on the political culture aspect of the Nordic peace, it is also important to explore the role of interdependence, common political institutions, and the development of a security community in the Nordic region. It is certainly important to avoid a tautology when discussing the importance of security community in the Nordic area-designating the Nordic zone of peace as a security community (as this research does) carries with it the possibility for a facile conclusion that it is peaceful because it is a security community. As Clive Archer points out, there are stated reasons that lead to the creation of a security community; it is not simply a self-reinforcing logic (Archer and Joenniemi 2003: 16). Importantly, as was noted earlier in this study, it is important to consider the uneven pace and nature of integration in the Nordic area that complicates (though does not negate) the idea of a Nordic security community. ${ }^{16}$

The development of a security community in the Nordic area was erroneously linked by Karl Deutsch and his cohort (1957) to the dissolution of the Norwegian/Swedish personal union in 1905, Ericson (2003: 24-25) and many other scholars have since revised that linkage to begin in earnest in the waning days of World War II. Furthermore, the explicit integration project in the region that typifies security communities was intensified by the

\footnotetext{
${ }^{16}$ See Arter 1998: 305-308, after Nils Andrén 1967, etc.; Bengdt Sundelius 1982.
} 
earliest stages of the Cold War. In any case, Nils Andrén's process of 'cobweb integration' in the Nordics began with deepened societal integration, in some ways brought on by the Nordic solidarity in the face of the Soviet threat (expressed in the Scandinavian states' public support for the Finnish in their battles for independence in 1939). Similarly, Charles Kupchan assigns this process the highest levels of importance as part of critical phases in the creation of stable peace (2010a,b).

Attitudinal integration was another important aspect of developing a security community in the Nordic region (Arter 1998 after Sundelius 1982: 182). Kupchan’s fourth and final phase of his stable peace process demands the "generation of new narratives," (2010b) and many authors attribute the successes of the Nordic Council in institutionalizing cooperation among states that long defined their relations with suspicion as instrumental in affecting that change. The proliferation in the region of homogenous social policy has also been a defining aspect of the Nordic zone of peace, and contributes to the formation of a security community (Arter 1998: 306; Archer and Joenniemi 2003: 16).

What of the security element within security communities? At times united by a common threat (the Soviet Union or Nazi Germany), the Nordic states have been public in their support of one another, however security assistance and cooperation in military terms among them is rarely forthcoming. Military cooperation however is not one of the central Deutschian tenets of a security community, and it plays a minimal role in assessing the existence of a security community. If one accepts Kacowicz's key stipulation that a pluralistic security community is defined, or at least typified, by a stable expectation of nonviolent change and conflict, then the Nordic area's historical record in 
the latter half of the twentieth century certainly reflects this condition. Similarly, using Deutsch's own metrics of security community development-predictable behavior, compatibility of widely-accepted-as-important values, and the ability of states within a region to assist with the needs of another regional counterpart-the Nordic area meets his standards.

\section{Factor 5: Ethnic and Cultural Homogeneity}

As the nature of conflict in the contemporary context most often entails internal, ethnic struggles for power and territory, the Nordic example is one that remains largely free of any such concerns. Compared with other hotspots for conflict, the Nordic region is largely homogenous in terms of shared histories, cultures and languages, with the obvious exception of Finland, though such divisions within its own borders are minimal as well. Internally, Norway and Sweden share similar ethnographic makeup, with large majorities of their populations descending from similar genetic stock. The indigenous Sami, and in other parts of the region, Inuit, who largely reside north of the Arctic Circle and whose influence in major population centers is negligible, represent the outstanding exceptions to those ethnographies. Additionally, concerning indigenous tribes in the northern extremes of the Nordic territories, where the Sami question has arisen in Nordic history it has been dealt with strictly through diplomatic means, as have the sovereignty concerns of the Inuit peoples.

Where ethnic divisions fostered the intrigue of foreign powers, the Nordic states also expressed a preference for diplomatic dealings in large measure. As was previously highlighted in earlier pages of this study, the Åland Islands question-wherein ethnically 
Swedish Ålanders expressed interest in the territory's reclamation by Sweden-was resolved with the explicit intent of avoiding violent confrontation. Sweden lost the chance to regain a territory it had long considered its own, but in the long run prevented future conflict with Finland as asymmetries disappeared in the following decades. Denmark’s approach to ethnic concerns was not always so peaceful, however the lessons of the Schleswig-Holstein Wars places its decision makers on an arc bent decidedly towards political resolution. To wit: the aforementioned plebiscite on the provinces in question resulted in only partial gains in territory (the rest chose to repatriate their land to Germany) and Iceland's dissolution of its union with Denmark was not only allowed for under the two countries' political agreement 25 years prior, but provoked no conflictoriented response from Denmark.

Whatever the motivation to find diplomatic common ground or to offer the same benefits of national life to ethnic minorities that the majorities would have, the result has been a resolutely peaceful interior within all five countries that compose the Nordic zone of peace. The added benefit of hosting very few regional or ethnic divisions has helped the Nordic states to deepen ties among its peoples and to build a long intraregional peace that has proved a model for peaceful resolution the world over. It should not be understood however that the Nordic zone of peace has been free of conflict, either within its own boundaries, or with extraregional powers. Where ethnic divisions tend to contribute in large part to conflict elsewhere, the relative lack of it in Norden is perceptible in its lack of ethnically driven violence. What, then, causes conflict to arise? The settlement of those conflicts prompts the following explanation for peace among Nordic states. 


\section{Factor 6: Satisfaction with the Territorial Status Quo}

Adding to the profile of the long peace in the Nordic area built by Clive Archer (1996; and Archer and Joenniemi 2003), Arie Kacowicz’s primary explanation for what allows peace to be created, and later, maintained is simple, but often overlooked or misconstrued as a settlement of economic resources. Kacowicz avers that a broad satisfaction with the territorial status quo is not only necessary for the development of a security community, but also sufficient for the onset of negative peace $(1995,1998)$. To characterize this satisfaction as a resource-related one is not wholly incorrect, but doing so only tells part of the story. At bottom, conflicts over resource are disputes over which nation-state exercises control over the territory on which, or under which, those resources lie.

Most general explanations for peace rely on some of the constructivist or geopolitical explanations for peace listed here and cataloged by Archer and Joenniemi (2003), however, too often they fail to place the region in perspective. In Arie Kacowicz's view, internal disputes may divide on ethnic lines, but the grievances of the belligerent parties are almost uniformly rooted in the control of territory. Similarly, he points to the vast majority of dyadic conflicts being waged over disputed territorial claims. In this way, regional peace is a function of the settlement of those claims writ large, where few, if any, other dyadic or domestic explanations for peace can serve the same function. Thus, in his estimation, the settlement of major territorial disputes not only presages peace, but also serves as a leading indicator in assessing the likelihood for future conflict (1995, 1998). That satisfaction, which he stipulates come from both domestic and international source, derive from a widely acknowledged comfort that territorial claims are settled. 
Viewed solely through the lens of the Nordic area, this assumption about territorial claims would be difficult to refute, as the evidence all aligns rather neatly in favor of his argument. For example, the last war between states in the region was over territorial claims (Sweden's claim to Norway, settled through war in 1814). Similarly, the only war unilaterally declared by any of the region's states since the advent of a Nordic zone of peace was waged-twice-over a territorial dispute (Denmark: Schleswig-Holstein Wars 1851-54, 1861). Accordingly, all other wars within the region have been prosecuted with aims of asserting sovereignty over a belligerent's homeland (particularly, Finland). But territorial disputes have also been responsible in large measure for the most heated nonwars of the past two centuries among the Nordic states and with extraregional actors.

Regarding hotly disputed non-wars, the historical record is rich with evidence to suggest that territorial disputes are also the most important determining factor in conflict in the Nordic area, if not war. Examples of territorial disputes that brought the Nordic states to escalated tensions (though not to violence) abound in the twentieth century: fisheries disputes between Iceland and the United Kingdom resulted in the 'Cod Wars' (but no casualties), similar disputes have taken place between Norway, Iceland, the Soviet Union, and later Russia all serve as testament to this fact. Often overlooked is the question of oil in the Nordic area, where any potential disputes were headed off by high-level diplomatic negotiation. When petroleum exploration was set to begin in the North Sea, Norway negotiated the division of the continental shelf with Denmark and the United Kingdom to determine an equitable settlement (Ministry of Petroleum and Energy, Kingdom of Norway: 2013). In terms of production, the settlement turned out to be anything but 
equitable, and Norway became extremely wealthy through the astute management of its resources while avoiding conflict.

With the land borders of each country settled by 1947 (Finland), each of the Nordic countries has been completely free of violent conflict of any kind. This is not to imply that conflict opportunities did not arise, they certainly did, but they were almost exclusively maritime disputes over economic exclusivity zones. With that understood, it would seem that Kacowicz's assertions about territorial satisfaction hold in the Nordic area. After the settlement of territorial disputes and the establishment of related norms, the Nordic region was at its most peaceful. The Nordic region became a true, but negative, zone of peace after Sweden's last campaign to conquer Norway. Not only was satisfaction with the territorial status quo the key to the advent of peace in the region, it also serves to explain its continuance.

\section{Conclusions: Assessing the Zone of Peace in the Nordic Area}

Studying the Nordic peace may be particularly relevant for another, less mature regional peace. This chapter was able to explain the Nordic peace and distill potential implications for peace in a new region. Additionally, and perhaps most importantly, this discussion focused on more than just the negative peace aspects of Norden's history; it also explored the historical elements of the movement towards a stable peace and fuller development of a security community. Above all, this chapter was able to confirm the presence of each explanation for peace that was offered, further lending credibility to the assumptions by other scholars, and solidifying a potential model for analysis in regions farther afield. 
The expected results of this chapter's analysis are able to confirm, or at least add significant credibility to, the claims of a Nordic zone of peace, and by extension security community. Also, what became clear through the analysis in the pages of this chapter is a relationship between democracy and the quality of peace in the Nordic regions. As expected, the assignation of the Nordic area as a zone of peace and a mature security community are upheld, however, their path to the latter is likely different than previously expected.

Some surprising results also turn up in this chapter. The level of security integration (in a military sense) is unorthodox when compared with other extant regions of peace. The low priority placed on military integration by the Nordic states is often confounding to those who analyze the region, but a lack of emphasis on defense cooperation has not yet impeded the deepening of integration processes or the existence of a security community. Another confounded assumption is laid bare in this analysis as well, as the elapsed time between the onset of a negative zone of peace and an incipient security community is longer than expected. Many scholars rely on Deutschian assumptions about the Nordic peace as a basic truism (that security community began in 1907), however, as Magnus Ericson points out, frank misgivings on the basis of security existed between Nordic states for some time after the 1905 dissolution of the personal union between Norway and Sweden. Moreover, the historical record shows that the period of stable peace between negative peace and security community has been surprisingly brief. Though it is impossible to pinpoint an exact year in which all of the Nordic states recognized each other's intent as benign, intraregionally oriented defense plans continued until, at earliest, 
the late 1920s. By 1948, the will to cooperate through security institutions had been formalized, beginning the security community phase in Norden (Hoydal). After no more than 20 years as a zone of stable peace, the Nordic region moved from the first phase to the third within Kacowicz’s framework.

A final unexpected result of the historical analysis conducted here is the extreme lack of uniformity among the Nordic states in terms of violence. Norway engaged in no violent conflicts after 1814, save an irregular resistance to Nazi occupation during the Second World War and participation in coalition-led conflicts in the Post-World War II era. Tilting even more toward the peaceful extreme is Iceland, which has maintained a pacific footing since the middle of the thirteenth century, both within the region and without.

Denmark and Finland however-hardly conceived of as warmongers in any modern context-present a study in contrasting experiences. Sweden successfully upheld, and rigorously embedded, its position on neutrality from the 1820s onward. Denmark took an entirely different tack. In response to secessionist movements in an ethnically ambiguous region to its south, Denmark entered into two wars, the second of which deeply scarred the psyches of Danish policy makers going forward. However, while the King of Sweden's attempts to express solidarity through military might were rebuffed by its parliament, Denmark's leadership expressed no such reservations in supporting the independence wars against the Soviets of both Estonia and Finland. Finland is also the only state in the group to have experienced civil war during the peace period, and its leaders showed no reluctance in revolting against repeated interference by the Soviets and the Nazis later. Despite this willingness to fight off extraregional influence, Finland 
showed no violent tendencies toward its regional neighbors during the long peace of the nineteenth and twentieth centuries.

The next chapter fields a nearly identical analysis of the Southern Cone with the intent of determining whether the causes of peace in the Nordic area can be understood more generally as explanations for peace, or whether they truly are exceptional in nature, thus limiting the value of the Nordic example in future peace studies. It will be interesting to discover whether some of the surprising results uncovered in this chapter will carry over to the Southern Cone's zone of peace, or whether they are endogenous results provoked by unique circumstances. In light of this chapter's results, determining the length of the stable zone of peace period will be of particular interest. If similar results are unearthed, then perhaps a new avenue for zones of peace research will be uncovered as well. Additionally, it will be interesting to assess the obvious differences in internal divisions within the Southern Cone and to determine whether they had a significant effect on the larger regional peace. Most importantly, the next chapter seeks to whether the Southern Cone zone of peace can be explained through generalized assumptions or whether it, too, constitutes a zone of peace that is termed too exceptional to be valuable in other assessments of peace. 


\section{A ZONE OF PEACE IN DEVELOPING WORLD: THE SOUTHERN CONE}

This chapter explains the evolution of peace in the Southern Cone. It accepts that a long peace, by the terms defined in Chapter I, has been in place in the Southern Cone since the conclusion of the War of the Triple Alliance in 1870. Peace in the Southern Cone is rarely treated in peace scholarship-I suspect that this is largely because of its record of spectacular internal violence and coups d'état-but it is worth exploring why countries with histories of violent regimes have not gone to war with each other since 1870 despite deep, lingering conflicts within their region. After delimiting the geography and defining the interpretation of the Southern Cone that is operationalized in this chapter, the study moves into a concise account of the region’s history with peace.

The crux of Chapter III rests on the insight revealed by the historical narrative. What can be inferred about this peace through the discussion of the paradigmatic Nordic peace analyzed in the preceding chapter? Immediately following the historical account is a direct questioning of the region's merits as a zone of peace. Does the Southern Cone clear the conceptual bar of a zone of peace? Does the Southern Cone move from negative peace to a stable zone of peace at any point its history? Importantly, can the Southern Cone be defined as a security community by the standards laid out by Kacowicz (1998) and accepted in Archer and Joenniemi (2003), and if so, at what level is the security community functioning, according to the Adler and Barnett (1998) typology? 


\section{Map III.1: South America}

\section{South America}

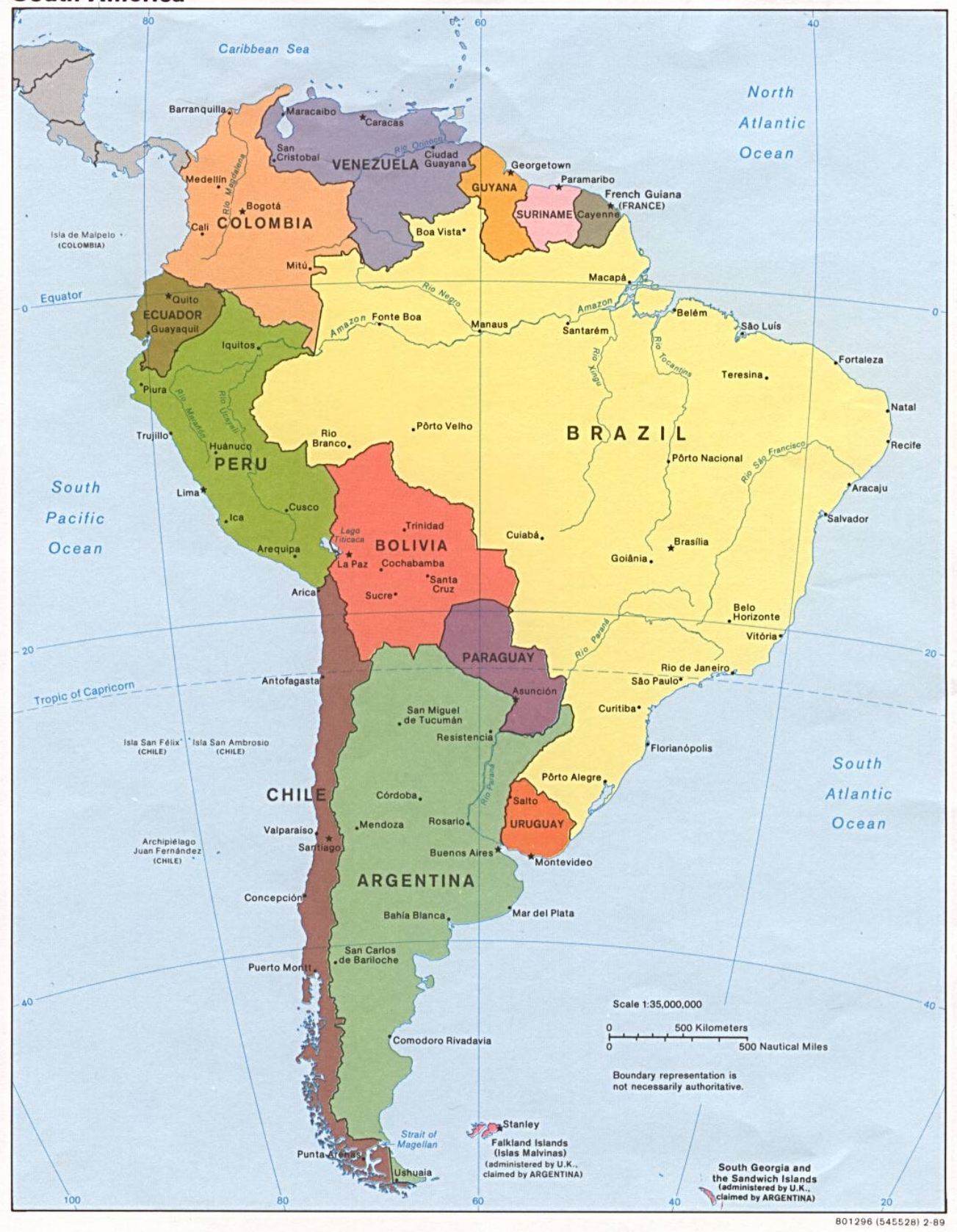


Map III.2: The Southern Cone

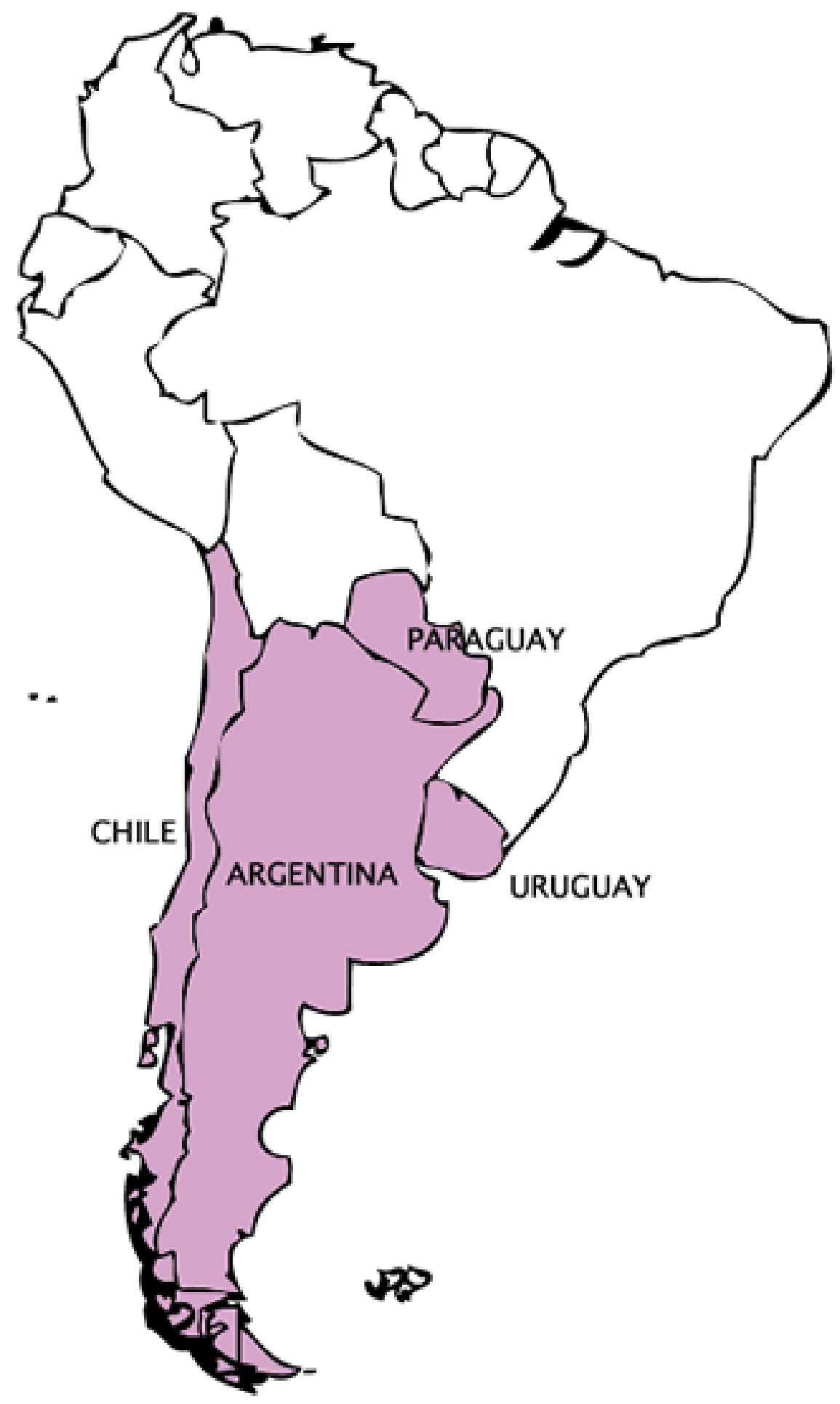


From that point, the research reviews the historical record and tests for correlations between the hypotheses about peace derived from the Nordic experience. For the purposes of this chapter, the now fleshed out explanations of the Nordic area's zone of peace have been reduced to basic hypotheses for use in analyzing the zone of peace in the Southern Cone. Additionally, the relationship between democracy and peace in the Southern Cone is discussed in detail. This chapter elucidates that a negative, and even stable, peace developed under the auspices of a set of regimes almost totally devoid of even nominal, procedural democracy. As a result, interesting questions about the relationship between democracy and deeper, sounder peace arise and are explored in the pages that follow.

Chapter III is driven by two fundamental objectives. First, it asks questions of the case of the Nordic peace in terms of applicability to other regional peace analyses. Second, and equally important, my research develops a broader understanding of the nature of peace in the Southern Cone. More than just a retelling of the region's history, Chapter III tests the effects of the aforementioned hypotheses about peace on the trajectory of intraregional international relations, and discusses the potential implications of the results. This chapter's treatment of the Southern Cone concludes with a brief discussion of the study's findings and the aptness of comparison between the Southern Cone and the Nordic area, as well as other regions in the developed and developing worlds.

\section{The Southern Cone in Geographical Context}

Of the two regions under scrutiny in this research, the Southern Cone certainly presents the most opportunities for contention and debate over its geographical boundaries. For 
the purposes of this study, the "thick" (seven countries included) and "thin" (which entails three countries' inclusion) definitions are explained, as well is the intermediate variations, in brief before the definition utilized herein. The purpose of this is twofold: (1) it serves to responsibly acknowledge competing views, and allows the reader to filter the results of this chapter accordingly; and (2) it also helps to clarify this research's position within this geographical debate, and offers a clear comparison that helps to explain why an intermediate, four country definition was chosen.

The geography in the Southern Cone remains a debated subject within zones of peace analyses, and within peace studies more broadly, however, there are some important commonalities in all accounts that should be explained first. What the available literature does not dispute is the inclusion of Argentina, Chile, and Uruguay within the composition of the Southern Cone region. Also not in dispute is that the region's southernmost area extends to the southern extreme of the South American continent and the whole of the Western Hemisphere. The bordering by the Atlantic and Pacific Oceans, as well as the inclusion of the Río de la Plata (River Plate) Estuary in the Southern Cone’s maritime and riverine geographies is also universally agreed upon with the literature. Additionally, the boundaries between the three countries are, for the most part, exceedingly clear, owing largely to obvious geographical separations. The separation between Argentina and Chile is, to a large degree, determined by the Andes mountain range while the division between Argentina and Uruguay is clarified by the confluence of aforementioned River Plate and the Uruguay River. Moreover, it should be noted that the combination of these three countries constitutes an obvious and unique tapered shape (hence the name 
'cone') distinct on the continent from the much wider latitudes that characterize most of South America’s territory.

The expansion of the region beyond the thinnest, minimal definition adopted for this study is also rooted in a larger methodological concern: symmetry. In my view, the importance of geographical symmetry between the units of analysis is an important methodological concern in comparative zones of peace analyses. The theoretical importance of symmetry should be clear in light of previous studies. My conclusions do not claim the results of previous case studies as invalid, nor seek to invalidate them, but a major factor in case selection for my research was the drive to compare two regions of roughly equal size. The cornerstone contribution to developing world comparative zones of peace study, Kacowicz's Zones of Peace in the Third World (1998), chose to compare two regions of vastly different proportion. In my view, the comparison of a continentSouth America-with a sub-continental, more clearly regionalized, area-West Africapresents a potential compromise to the validity of the prescriptions emanating from the research. Logically, comparing the management of peace, particularly with the involvement of regional institutions, of a whole continent to that of a cluster of states (though numerically they might be similar) presents certain difficulties with deriving generalizations about peace.

The present study's aim of creating greater symmetry between the two cases is not the only reason for shrinking the number of states included in the unit of analysis. Ambiguities in definition of the Southern Cone abound in both geography and international relations scholarship. The amorphous definition of the Southern Cone arises 
from the varying perspectives that prompt inclusion of one country or another, and is usually divided along strict, geographical lines and conceptual or cultural ones. In a purely geographical sense, the inclusion of Brazil, from the state of São Paulo southward, should be clear as this collection of states in Southern Brazil do help to form the geographical shape of the Southern Cone. However, difficulties arise in international relations research when attempting to make generalizations about state behavior based on only a portion of a sovereign state without autonomy in its foreign policy decisions.

Adding to the complications of Brazil's inclusion in Southern Cone analyses is the fact that Brazil's territory extends to northward and westward to a point where that territory is more linked with South American countries that are decidedly not part of the Sothern Cone (Peru, Venezuela, etc.). It would be difficult indeed to limit Brazil’s influence or relations in any real way to those with its southern neighbors. Admittedly, many studies on peace in the Southern Cone focus on the Argentina-Brazil dyad, but the relationship between South America's two largest countries will be treated here as a relationship between regional and extraregional actors (it should be noted that Jan Knippers Black [2011] characterizes the relationship identically) most analogous to the relationship between Sweden and Russia in the Nordic context-where the larger state if not wholly of the region, but the region cannot be well understood without accounting for its role. For all of these reasons, this study excludes Brazil.

The inclusions of Bolivia and Ecuador in the thickest definitions of the Southern Cone also prove problematic. Though there exist several notable examples of Bolivia's inclusion into the Southern Cone (see Kacowicz 1998; Oelsner 2003), and at least one 
prominent example of Ecuador's inclusion (Kacowicz 1998: 67), I find their insertion into the debate of the region's boundaries problematic. The other countries commonly included in the Southern Cone pose significant cultural, ethnic, and historical divergences from both Andean countries. Whatever the differences are at the cultural and ethnic levels (space limitations of the present study prevent fuller explication), their inclusion in the Southern Cone is also confounded by institutionalized regional self-identification. Both countries are important members of one of South America's major regional organizations: Comunidad Andina (Andean Community). Notably, the Andean Community customs union includes none of the countries listed here as geographically and culturally part of the Southern Cone (while a parallel customs union, Mercosur, does). ${ }^{17}$ Most importantly perhaps, neither Bolivia nor Ecuador lies fully within the physical "cone" landmass of South America. ${ }^{18}$ Given their respective geographical settings, their organizational and identity affiliations, as well as the fact that each of the two countries has closer cultural ties with the other than with the rest of the Southern Cone, their exclusion from this study is at least logical, if not universally accepted.

Conversely, if cultural identities were the most important qualifier for inclusion in the region, Paraguay would likely be excluded, and in some studies is. My thesis takes the opposite tack however, by placing higher value on physical location, and historical and organizational ties. Viewed through this prism, the inclusion of Paraguay is well

\footnotetext{
${ }^{17}$ Although Mercosur also includes Brazil and recently added Venezuela to its bloc.

${ }^{18}$ Bolivia's territory does in reside in part in the Southern Cone, however, it could logically be excluded on the same grounds as Brazil regarding differentiated foreign policies from the central government of the country.
} 
reasoned. Located directly to the north of Argentina, the southeast of Bolivia, and to Brazil's southwest, the whole of Paraguay is still within the Southern Cone's physical zone of inclusion. Compounding this argument is the extraordinarily rich history of rivalry with Argentina and Uruguay, facilitated largely by shared navigability between those countries and Paraguay. Though its rivalry with Bolivia is important, the Chacoone of the world's most inhospitable territories for human life-is, and has long been, sparsely populated. The rivalry between the two countries occurred largely because of a dispute over natural resource exploration on a previously unimportant piece of land. The war that Paraguay fought with Argentina, Brazil, and Uruguay left a lasting impression on Paraguay's history and politics, and resulted in the loss of significant amounts of territory. Thus, it could credibly be argued that Paraguay's rivalries with its eastern, southern, and southeastern regional neighbors hold greater sway over Paraguay's international relations and national identity. Combining geography with historical ties makes Paraguay an obvious choice for inclusion in any analysis of the regional dynamics in the Southern Cone.

Having fully explained the geography of the Southern Cone, the case study proceeds with a look at its shared history, placing a particular emphasis on the regional dynamics of war and peace in the region since 1870 . Though most studies of the area begin with an explanation of the region as they define it, few authors justify the exclusion or inclusion of the countries that compose their definitions of the Southern Cone. In this manner, this study diverges from the paths of many other similar studies. Because this research proceeds to analyze the region as a laboratory for understanding an unconventional 
peace, and seeks to understand the relationship between the hypotheses of earlier chapters and the maturation of a zone of peace, a clear definition of the unit of analysis is valuable in determining the worth of this comparison's results.

Map III.3: The Southern Cone (Detail)

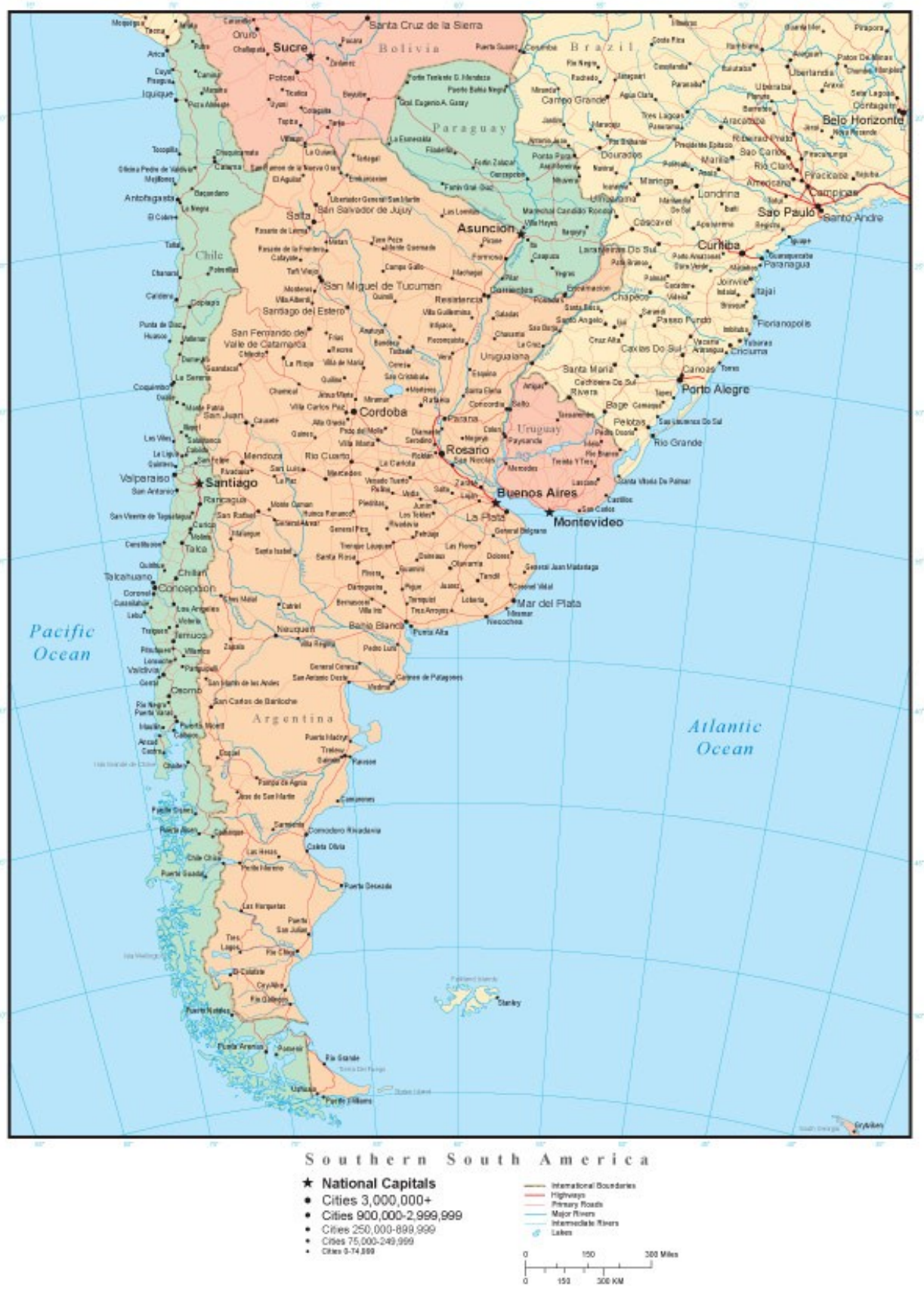




\section{Constructing a Narrative: Regional Peace in the Southern Cone}

While South America as a whole shares a significant number of historical and linguistic ties, the identification of the continent as a region unto itself can be viewed as problematic, as a regional South American identity is both loose and largely unaccounted for in international relations or sociological literature. The advent and development of the Union of South American Nations (UNASUR) is a significant, though still largely incomplete, step toward strengthening pan-South American ties. Within the scope of zones of peace studies, its designation as both a region, and a zone of peace, also presents significant obstacles to sound research. Though South America is, and long has been, largely peaceful since 1883, its history offers some glaring examples of interrupted peace in the intervening decades between then and now. ${ }^{19}$ Accordingly, my research views the Southern Cone as a unique zone of peace unto itself, and while other studies have espoused similar views, few, if any, have defined the region in the same way as this study: including only Argentina, Chile, Paraguay, and Uruguay.

This section of the thesis aims to construct a concise but thorough historical narrative of the region as a zone of peace. The section is segmented thematically along four historical milestones: post-independence and pre-peace; the advent of a regional negative peace; the onset of stable peace; and the possibility of a security community. Before moving to analyze the relationship between my hypotheses about peace and the Southern Cone's

\footnotetext{
${ }^{19}$ Notably, the Chaco War between Bolivia and Paraguay (1932-1935), and the three wars in the twentieth century fought between Ecuador and Peru (1941, 1981, 1995).
} 
experience, this section concludes with a direct look at Kacowicz's framework for zones of peace in relation to the historical narrative constructed here.

The information presented in this section will help answer the following questions: Is the Southern Cone truly a zone of peace? What bearing did democratic reform have on the character of the peace perceptible in the Southern Cone? Has the Southern Cone undertaken the construction of a security community, and if so, to what level? After answering this set of questions, the next sections follow up with a direct analysis of my hypotheses and some final thoughts on the results of that analysis before moving into the study's final chapter.

Map III.4: Colonial South America

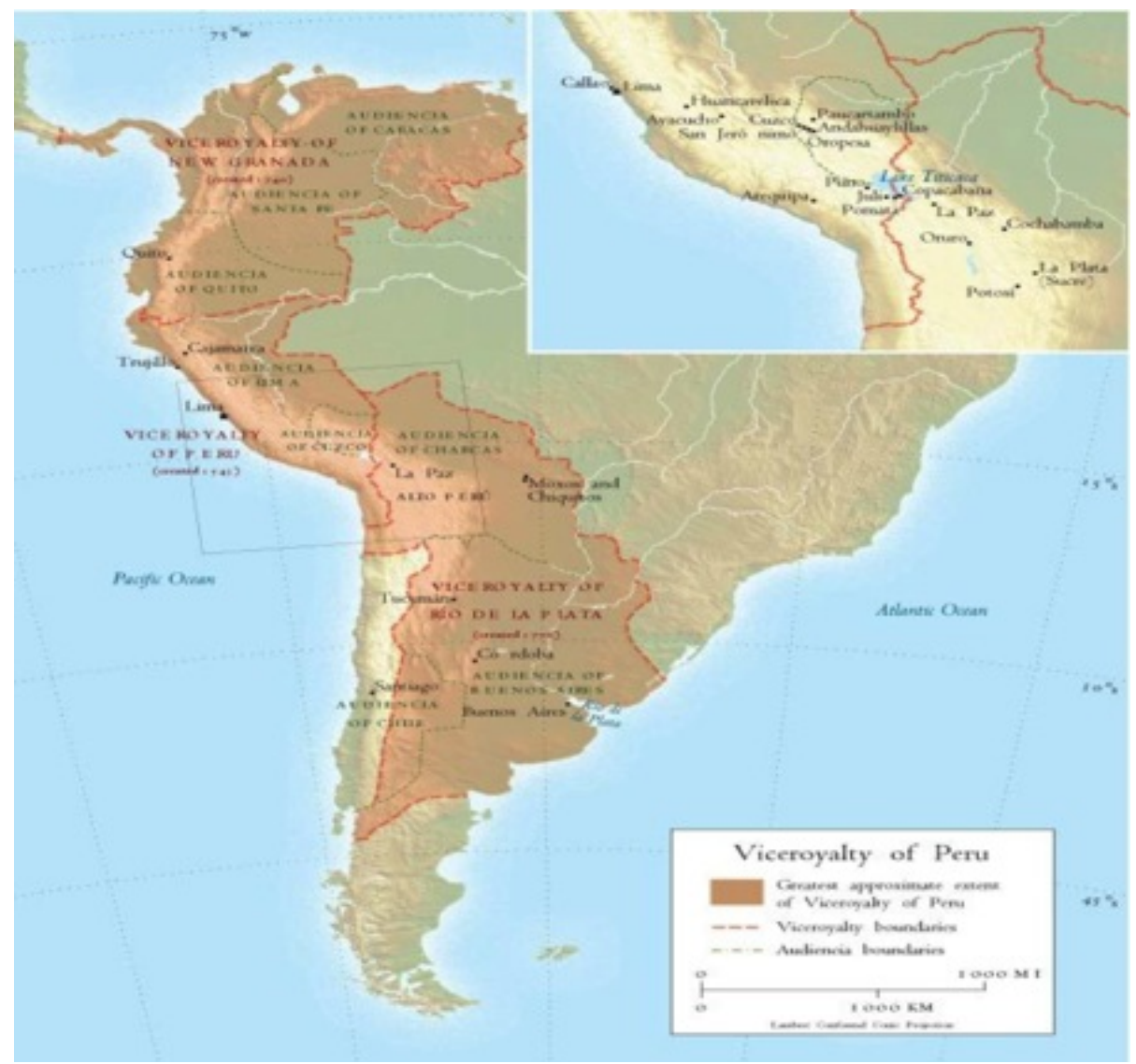


Coming to Peace: The Southern Cone before 1870

Before the arrivals of the Spanish and Portuguese to South America, the territories of the Southern Cone were largely detached in cultural and physical terms. Sparsely populated (Burkholder and Johnson 2008: 338) and separated by imposing physical barriers. Uniform native experiences between the four countries in question were nearly impossible. Though the Inca were successful in controlling a large swath of South America, their influence south of the Atacama Desert (which covers roughly the northern third of present day Chile and a significant portion of southern Peru) and east of the Andes was limited. Chile’s indigenous tribes, known as the Mapuche (or Araucanía by the Spanish) and Tehuelche, held sway over the isolated territory of what is today central Chile. Paraguay was more populous than Argentina and Uruguay preceding contact with the Spanish, and within the territory of modern Paraguayan state, there existed five major linguistic divisions among a large number of nomadic tribes. The countries of the La Plata Basin were largely uninhabited prior to contact with Iberian explorers, though Argentina was certainly more populated than Uruguay.

The beginnings of a cohesive regional identity were formed under the auspices of European colonization. The European discovery phase brought Spanish and, in the case of Uruguay, Portuguese explorers to the region for reasons already well-worn by an abundance of historical contributions on the subject. Interestingly, though much of Spanish South America was held relatively firmly under the control of the Viceroyalty of Peru, each of the countries under analysis here managed to distinguish themselves from Peru’s control. Argentina, particularly Buenos Aires, earned significant notoriety during 
colonial times as an alternate shipping point for merchants who wished to avoid both the unwieldy traveling distance to Peru and the levying of Spain's taxes. Eventually, the Spanish crown compromised. Realizing its inability to halt shipments from Buenos Aires, Spain established present-day Argentina's principal city as the capital of the new Viceroyalty of the Río de la Plata. Chile began as a sanctioned expedition from Peru with permission from Francisco Pizarro, though the Spanish explorer, Pedro de Valdívia did not receive his hoped-for title of governor of the lands to be settled. After hearing of Pizarro’s death Valdívia immediately proclaimed himself royal governor and received permission from the Spanish Crown for Chile to proceed in self-government as its own outpost of the Spanish Empire.

Paraguay, discovered in 1516 by the Spanish began as its own province. The expeditions that re-founded Buenos Aires and began European habitation of Santa Cruz de la Sierra, a major city in the east of present-day Bolivia, departed from Asunción. Unlike many other Spanish colonies where the indigenous population was decimated by disease and brutality, significant numbers of indigenous peoples remain a large part of the ethnography of Paraguay today and accounts for Paraguay's second official language: Guaraní. During the colonial period, Jesuits largely controlled the province and built reductions in an attempt to shield local indigenous populations from the brutality of slavery, but more importantly, with the intent to fashion a Christian country of 
indigenous people (Burkholder and Johnson 2008: 100, 339; UNESCO). ${ }^{20}$ By contrast, Uruguay was a much lower priority for Spanish colonization than the other three Southern Cone states. Initial Spanish attempts to settle Uruguay were met with considerable resistance (Burkholder and Johnson 2008: 338). When combined with the lack of exploitable minerals, indigenous resistance compelled the Spanish to place little emphasis on settling present-day Uruguay. In the late seventeenth century, the Portuguese settled in modern-day Uruguay, laying the groundwork for what would be one of the enduring rivalries of the next two centuries: that between Argentina and Brazil for influence in the trans-Platine province.

Capitalizing on Napoleon's capture of the Spanish king and subsequent weakness of the Spanish Empire in the early nineteenth century, most of Spanish America's elite classes began to militate for independence against their rulers in Madrid. Paraguay was the first among the Southern Cone states to achieve independence. Its unique historical trajectory remains marked by the rule of a dictator, José Rodríguez de Francia, who governed the country until 1840, closing off contact with the rest of Paraguay's neighbors and mandating its citizens marry interracially in order to create a mestizo society based on the writings of famed political philosopher Jean Jacques Rousseau. His time as president was succeeded most notably by two more long-ruling dictators, the second of whom, Francisco Solano López, is widely viewed as the instigator of what would be the region's last internal war: the Paraguayan War, or the War of the Triple Alliance.

\footnotetext{
${ }^{20}$ Reductions were resettlement projects, built as small cities unto themselves, that came about as a result of the Toledo reforms of 1567 and were organized by the region's Franciscan and Jesuit orders. Their purpose was to Christianize the indigenous population while placing it under direct control of the colonial state.
} 
Argentina's post-independence decades followed a similarly grim trajectory. Most of the nineteenth century was marked by civil wars and a bitter relationship with Uruguay, as well as its own war for independence against Spain, and later, an allied war against Paraguay. The complicated history of Argentina's nineteenth century seems best summarized as chaotic. The 1820s began with the dissolution of centralized government from Buenos Aires and ended in war with Brazil (1825-1830) over the fate of the rogue Banda Oriental province, which would become known as Uruguay. The series of civil wars fought in the ensuing decades were wars intended to pacify Argentina's provinces and unite them under the central government of Buenos Aires, but they resulted in a tenuous peace in which Juan Manuel de Rosas emerged as the country's de facto dictator in the middle decades of the nineteenth century. This agreement failed to quell violence in and around Argentina, which would be at the center of two separate European blockades and a war to conquer the Tarija province of Bolivia during the War of the Confederation (1838-1840). Argentina's violent midcentury dovetailed into the War of the Triple Alliance, fought as an ally of Brazil and Uruguay against the aforementioned Francisco Solano Lopez, who sought more territory and sea access for Paraguay. Importantly, the Paraguayan War came on the heels of the first semblance of the modern Argentine republic under the leadership of the country's first elected president, Bartolomé Mitre, in 1862.

Uruguay's role in the region is certainly unique, but in the pre-peace decades of the nineteenth century, the trans-Platine country was deeply linked to Argentina, and to a lesser extent, Paraguay. Immediately after Argentina threw off Spanish rule, Montevideo 
was named the new capital of the fast-crumbling Viceroyalty of Río de la Plata. José Gervasio Artigas fought to rid the Banda Oriental (as Uruguay was known at the time) of the Spanish, and was a fierce advocate for provincial independence from both Spain, and the resulting government in Buenos Aires. His actions to retake Montevideo from the forces of Buenos Aires were not looked on favorably by either their cross-river neighbors or Portuguese Brazil, the latter of which moved into Uruguay and annexed it as its own province, Cisplatina. As the Centralists in Argentina sought to reclaim the contested Banda Oriental province (as Uruguay was formerly known), they entered into war with Brazil that ended in Uruguay's recognized independence in 1830. Less than a decade later, the Uruguayan Civil War (1839-1851) began, and violence again consumed Uruguay. Interventionist forces from Argentina and Brazil were involved in supporting the warring factions, the Blancos and the Colorados (Whites and Reds), which were the two dominant political parties vying for control of Uruguay’s fate. After Uruguay’s civil war concluded, Brazil was guaranteed the right to intervene in its foreign affairs, thus intensifying its growing rivalry with what would become Argentina (as it is known today) until the consolidation of the modern Argentina a little over a decade later. By 1865, Uruguay had dutifully joined Argentina and Brazil in beating back attempts by Paraguay’s Solano López to gain access to the sea.

Chile, as a consequence of its extreme topography remained largely isolated from its neighbors to the east after Argentine freedom fighters helped it to secure its independence from Spain in 1818. Separated from Argentina by the Andes on its eastern border and the inhospitable Atacama Desert in its north, Chile was a very difficult territory to penetrate 
for its neighbors with underdeveloped navies. The treaty it signed in 1856 with Argentina was an attempt to resolve territorial claims that helped both countries avoid aggression towards each other in the following decades. In many respects, the isolation it enjoyed from broader South America was responsible for creating a highly homogenized society that was also quite differentiated from its neighbors. Unlike the Argentine and Uruguayan experiences, Chile remained blissfully free of shared (or for that matter, divergent) political agendas that spoiled its national consolidation processes. In the case of the Chincha Islands War (1864-1866), Chile allied with Bolivia, Ecuador, and Peru to remove Spain from South America's Pacific coast, following the path of so many of the formerly Spanish colonies in removing their former rulers from the continent. Beyond that war, Chile's nineteenth century was largely free of violence when contrasted with the fates of its Southern Cone counterparts, though its consolidation processes involved a brief civil war and subsequent flare up as well as an indigenous pacification campaigns that were successful in expanding central government control further southward, although left a significant contingent of Mapuche, whose contests with the central government extend into modern times. Chile's government is anomalous within South American history in that its remarkably stable record of democratically elected leaders has also seen it largely free of coups d'état, particularly in the nineteenth century. 
Map III.5: Post-Independence South America, 1826

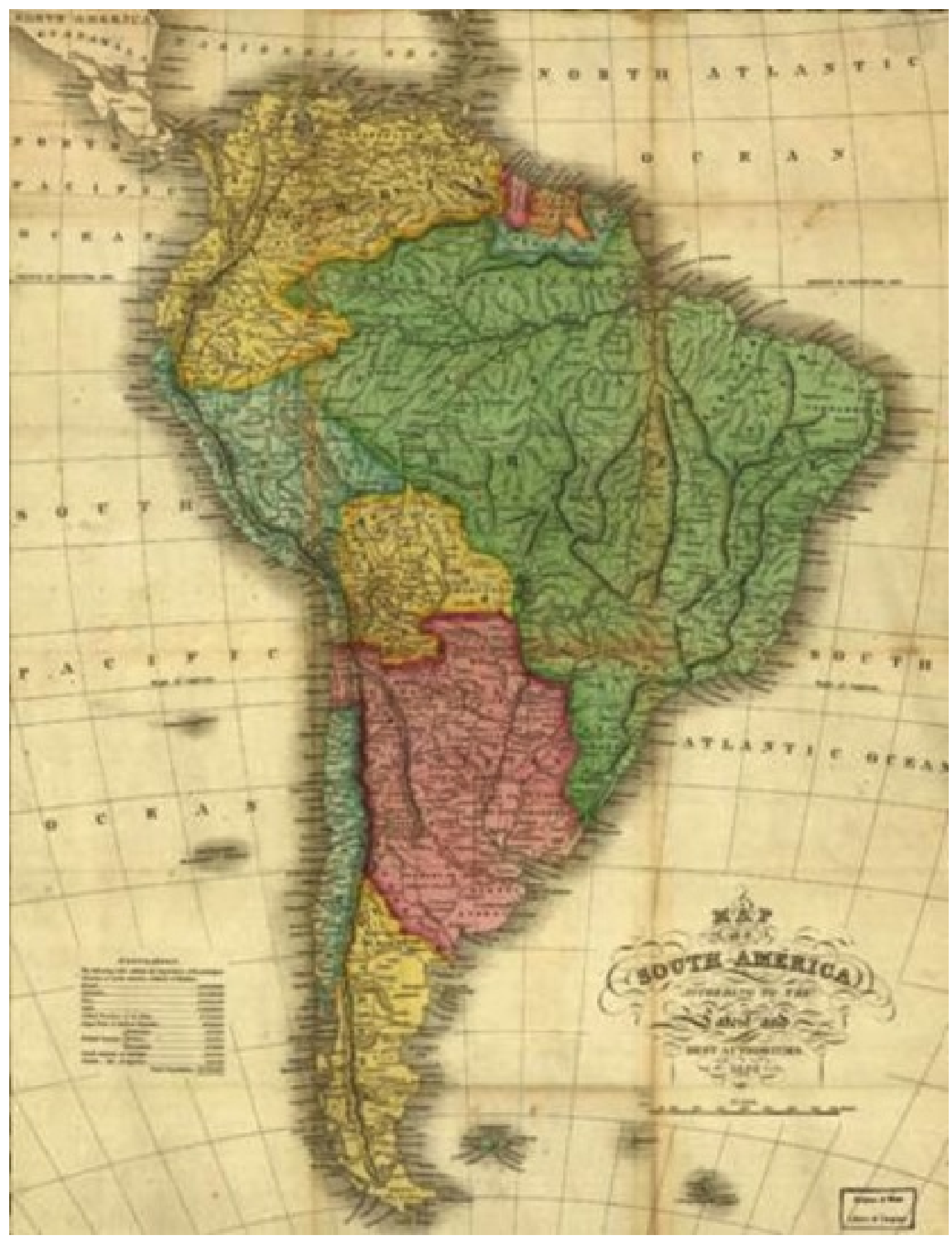


Table III.1: Independence in the Southern Cone

\begin{tabular}{|l|l|}
\multicolumn{1}{|c|}{ Country } & Independence Declared (Country) \\
\hline Argentina & 1816 (Spain) \\
\hline Chile & 1818 (Spain) \\
\hline Paraguay & 1811 (Spain) \\
\hline Uruguay & 1825 (Empire of Brazil) \\
\hline
\end{tabular}

Map III.6: War of the Triple Alliance (Paraguayan War), 1864-1870

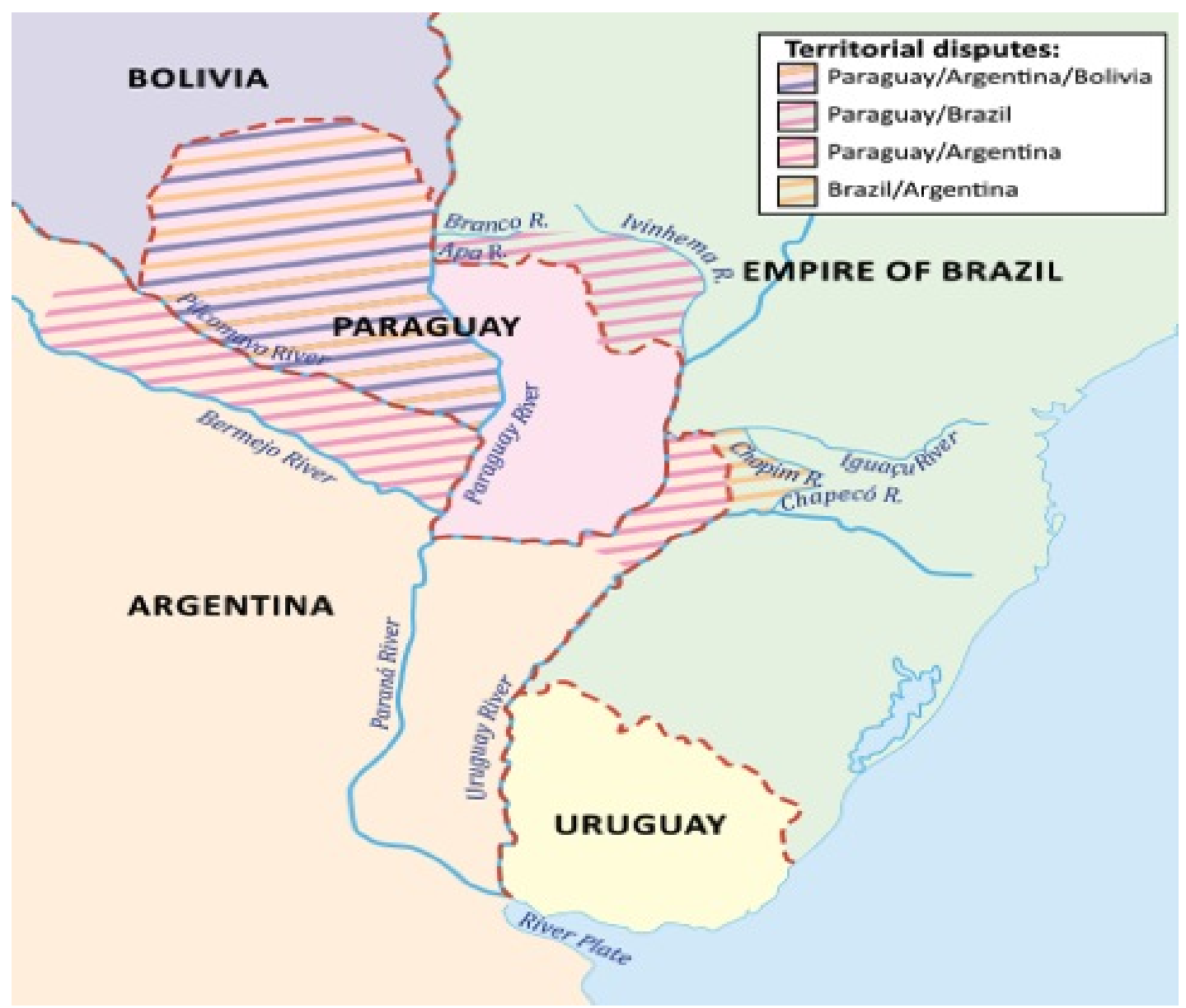


Negative Peace: Tense Relations in the Southern Cone, 1870 to the Early 1980s

At the conclusion of the Paraguayan War, the Southern Cone entered into a prolonged period of negative peace among its states. That war's end should not be confused for a total lack of war conducted by the region's states, but it does mark the cessation of intraregional hostilities. During the century that followed the War of the Triple Alliance, none of the four countries went to war with one another, and rarely went to war with any extraregional actors. Despite considerable domestic turmoil, this period should be understood as the first gradation of a zone of peace.

Though very little changed in Chile regarding intraregional violence-its borders buffeted it from involvement in the internecine conflicts of its neighbors-the main topic of analysis for this negative zone of peace phase is Chile's involvement in two major violent conflicts. Of note, the War of the Pacific (1879-1883), and its 1891 Civil War would come to represent the last two wars that Chile participated in. The War of the Pacific would have far-reaching effects in the landscape of Chile's foreign policy, coloring its relationship with Bolivia, and to a lesser extent, Peru into modern times. The result of the war over nitrates (saltpeter and guano) was Chilean territorial gain from both of its enemies, and Chile’s territorial gains in the war reduced Bolivia to being a landlocked country ever since.

During that time, Argentina and Chile signed an 1881 boundary treaty that would lay the groundwork for conflict between the two countries for the next century: disputed control over the Beagle Channel in the extreme south of both country's territories. Ten years later, Chilean political rifts came to the fore, pitting the president, José Manuel 
Balmaceda and the Army of Chile against Chile's congress and the Navy of Chile. The Chilean Civil War of 1891 ended with the defeat of the army by the navy and the escape and suicide of President Balmaceda, who was replaced by Jorge Montt as the head of a new, parliamentary republic.

1891 would prove to be an exceptionally eventful year in Chile. That year marked the beginning of Chile's experiment with a pseudo-parliamentary system that lasted until the mid-1920s. It was also a year of intensified international crisis for Chile. Shortly after the conclusion of the Chilean Civil War, tensions with the United States over naval dominance came to a head when two American sailors were killed (eighteen were wounded) by a mob in Valparaiso, Chile. Perceiving an opportunity for territorial gain, Argentina made clear overtures to the United States and offered to allow American military staging in their territory for an attack on Chile on the condition that Southern Chile be ceded to them at the conclusion of the war. Chile secured a peaceful resolution with the United States, but the Argentine willingness to aid a potential enemy amid revisionist claims over the recently signed boundary treaty tainted any feelings of goodwill between the two governments for the next decade.

The Pactos de Mayo (May Agreements), a treaty signed by Argentina and Chile in 1902 solidified then-crumbling relations between the two major powers of the Southern Cone and touched off five decades of conflict-free relations, until 1952's Snipe Incident reignited conflict over the disputed Beagle Channel. In those intervening decades, Argentina would undergo a very different experience than Chile with its internal politics. After the consolidation of the Argentine Republic in 1862, Argentina successfully 
claimed and added Patagonian territory to its land during the 1870s, and signed a boundary treaty in 1881 with Chile that sought to recognize territorial claims identically to the pre-independence period of 1810. In contrast to the middle decades of the nineteenth century, from the 1880s forward Argentina underwent an extraordinary period of democratic development and economic growth, making it one of the world's richest countries by the turn of the twentieth century. Buoyed by waves of immigration from Italy and Spain, and to a lesser extent, Germany, Argentina built a union-driven labor economy that would have repercussions in Argentine ethnography and politics deep into the future.

In 1933 however, like the rest of the world, Argentina suffered tremendous economic shocks that proved insurmountable for the sitting government, sparking a military coups d'état. This signified the beginning of a trend that defined the latter two-thirds of Argentina's twentieth century history. Over the next five decades, Argentina experienced repeated military interventions usurping duly elected governments or other military juntas. This cyclical process had a significant destabilizing impact on Argentine politics, and perhaps more significantly, on economic stability. During this prolonged period of political upheaval, a sort of golden age, known as the Peronato, where one of Argentina's defining political leaders maintained control of the government for ten years, marked the middle of the twentieth century. Juan Domingo Perón’s impact on the shape of Argentine politics, and domestic unrest, in the twentieth century would be difficult to overstate. The political party bearing his name-the Justicialist Party, or Peronist-has at times been outlawed by ruling military juntas, and his return to Argentine politics brought about the 
onset of what is likely Argentina's most infamous military dictatorship, that led by Jorge Rafael Videla from 1976-1983.

During those middle decades of political instability, Argentina's relationships with its neighbors were marked by the deepening of its major historical rivalries with Brazil and Chile, as well as a macabre spirit of cooperation among parallel anti-communist military dictatorships in those same states and those on the periphery of Southern Cone power dynamics: Paraguay and Uruguay. Despite basic agreement between each country's military dictatorships on the need to stamp out communism and other forms of dissident behavior, the rivalry with Brazil remained firmly intact as each country's leaders worried about the prospect of aggressive territorial claims by the other, and prepared their defense strategies thematically in alignment with this concern. Perhaps strangely, ArgentineBrazilian relations only experienced one direct, significant dispute during this period that over the damming of the Paraná River to support a power grid that would supply power to both Brazil and Paraguay. Argentine concerns over water resource determination drove diplomatic relations between the two South American giants for the better part of the next decade, but the dispute was resolved 1979. Two non-democratic military juntas, it should be noted, resolved the last major dispute between the Argentine and Brazilian governments. This fact constitutes a significant blow to the case of the democratic peace, as these two important South American countries settled the bulk of whatever contentious relationship they traditionally held through this resolution.

Argentine relations with Chile were also particularly sour during the second half of the twentieth century, and highly tense diplomatic situations were a mainstay in their 
bilateral relations. As each country tried, unsuccessfully, to assert legitimate authority over the Beagle Channel and other Patagonian areas of ambiguous authority during the latter half of the twentieth century, they became mired in diplomatic disputes and militarized, though primarily non-violent, confrontations. The incident at Laguna del Desierto (Desert Lagoon) in Patagonia provides some challenge to this study's claim of peaceful interstate relations in the Southern Cone, though with deeper analysis, the November 1965 incident acquits itself as both unintentional and not decidedly military in nature. The battle was a confrontation between the gendarmeries of each country that left one killed and another injured. Critically, the gendarmerie is rarely classified as regular military (rather, more akin to federal police) and the Argentine aggression was specifically forbidden in public statements by Argentina’s then-President Illía. The resolution to the crisis is perhaps more telling about the region's preference for peace. Chile invoked diplomatic meetings to resolve the dispute, and escalated the larger territorial dispute to international arbitration, rather than opting for war at a time when the Argentine regime was weakened over what was termed the Perón question.

A mainstay of the Argentine-Chilean relationship during this period was the aforementioned Beagle Conflict (map III.7), during which neither country had succeeded in legitimizing their authority over uninhabited territory south of the Straits of Magellan. Although the territory was nominally under the control of Chile as a result of the 1881 boundary treaty, Argentina's leaders did not accept those terms and aggressively pursued control of some of the channel's islands. Chile brought the dispute to international arbitration by the United Nations in 1971, which ruled (six years later) in favor of Chile 
retaining control of Lennox, Nueva, and Picton Islands. Argentina disagreed with the tribunal's decision and began planning for war. As Argentina moved to retake the islands by invasion, an emissary for Pope John Paul II brought a message to the leaders of both countries asking them to reach a peaceful resolution. As a result, Argentina halted its troop movements and returned to the negotiating table with Chile. The dispute was resolved diplomatically between representatives of each country's military dictatorship, however relations between the two countries remained chilled until Argentina's transition to democracy in the mid-1980s. During the period of poor relations between the two neighbors, Chile was instrumental in providing information to the United Kingdom in the Falklands War against Argentina, stoking antagonism in an already precarious situation.

Map III.7: Disputed Claims and Resolution to Beagle Conflict

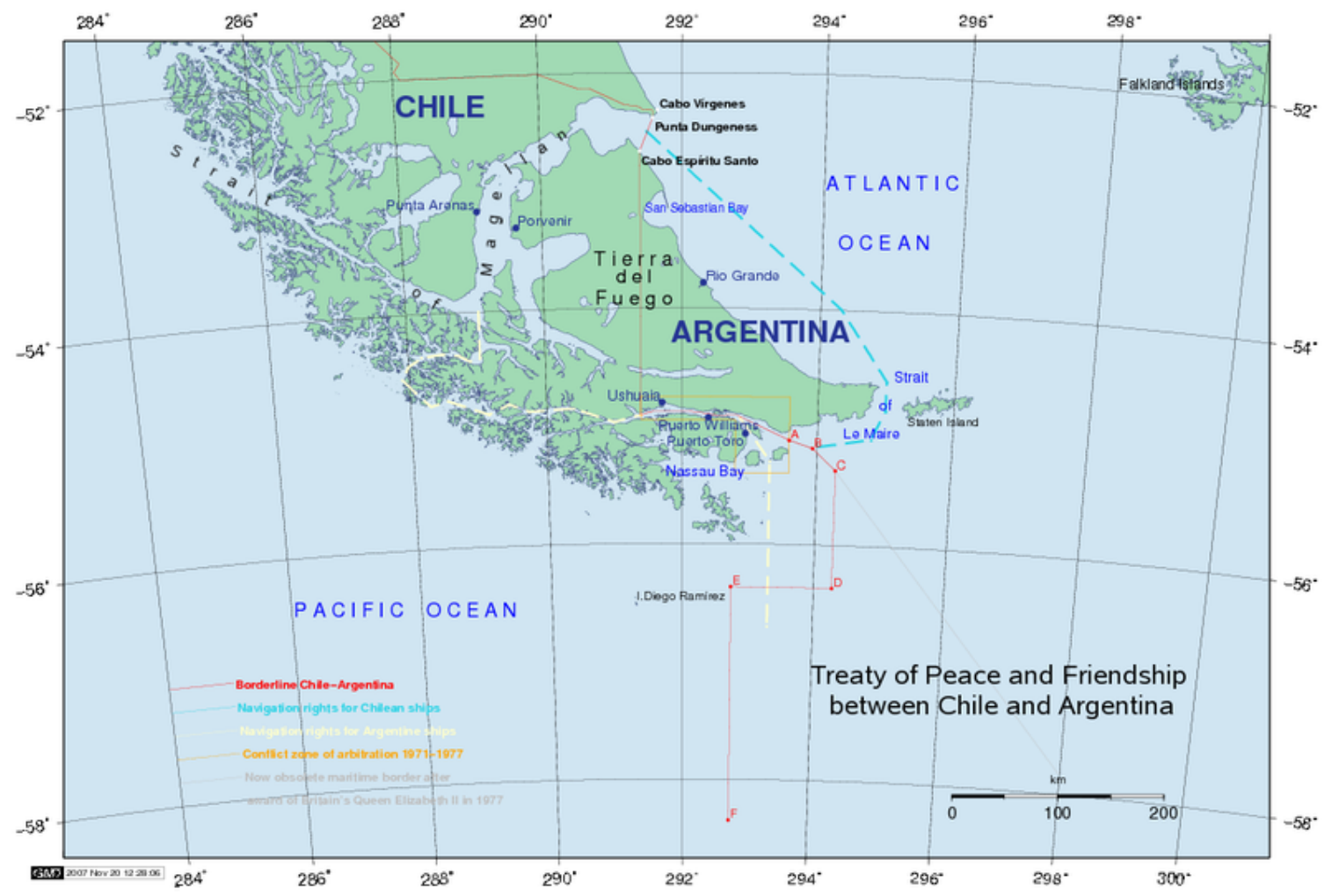


Map III.8: The Falklands War (1982)

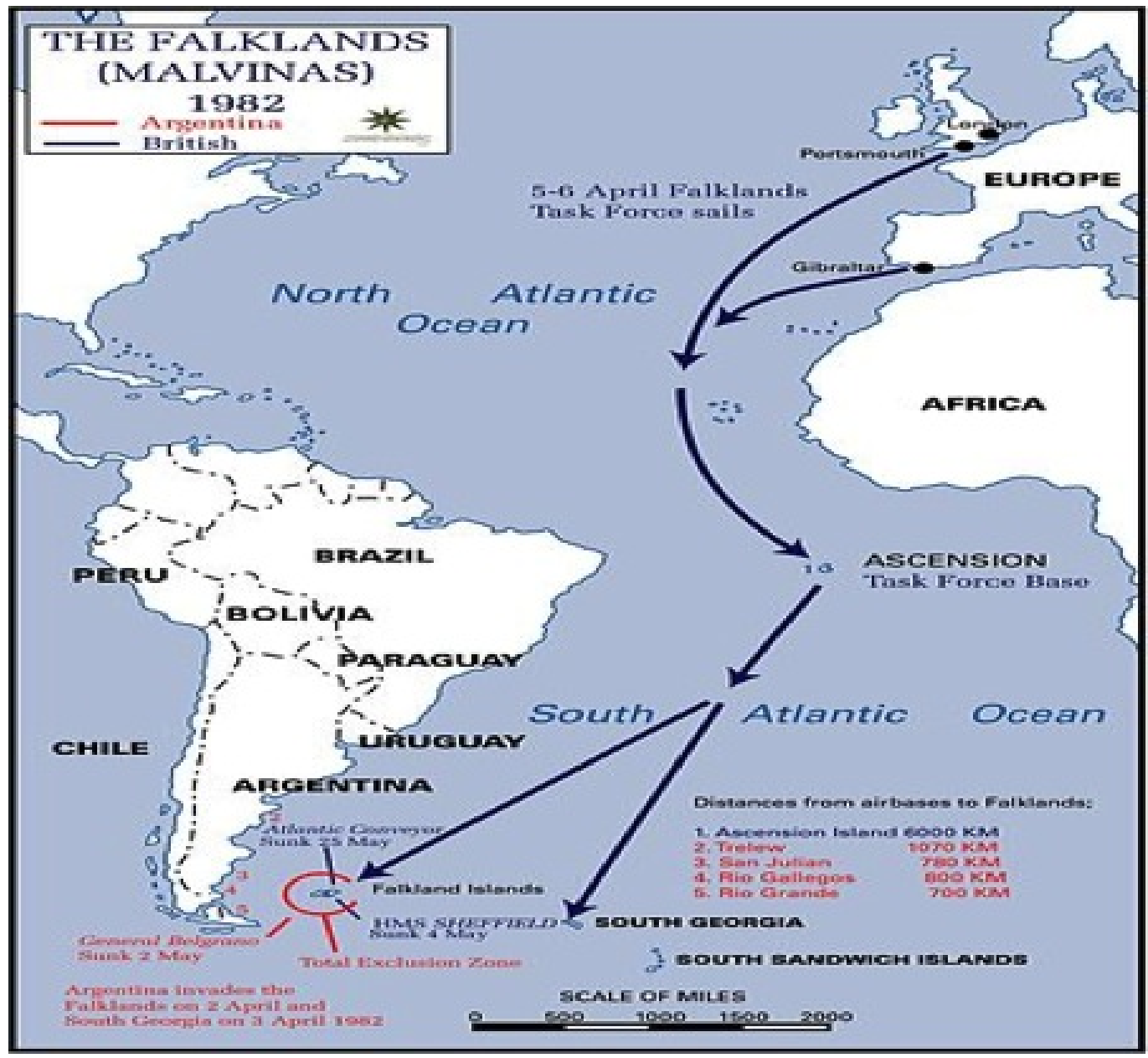

Uruguay and Paraguay enjoyed relative freedom from the Great Power politics during the negative peace period. Each country's history of that time was largely defined by domestic instability that resulted in dictatorial government. The beginning of the twentieth century was particularly turbulent for Paraguay and its politics. In the span of five decades (1904-1954), Paraguay had 31 different presidents, most of whom were deposed through violence as opposed to the ballot box. Two wars important in Paraguay's history took place in the first half of the twentieth century: the Chaco War (1932-1935) with Bolivia, and the Paraguayan Civil War of 1947. Paraguay's 
exceptionally bloody war with Bolivia over an inhospitable territory thought to be rich in oil reserves was sparked in part by the perceived need of each country to make up for being landlocked, and seizing an opportunity to bolster their flagging economies. Each was promised exceptional wealth by the Royal Dutch Shell (Paraguay) and Standard Oil (Bolivia) companies if they were able to control and exploit the territory at issue. Significantly, each side suffered heavy casualties in the pursuit of territory that was later found to have no commercially viable oil reserves until modern exploration and extraction techniques made it viable in 2012 (MercoPress 2012), compounding the losses in the eyes of many historians on the conflict.

Map III.9: The Chaco War, 1932-1935

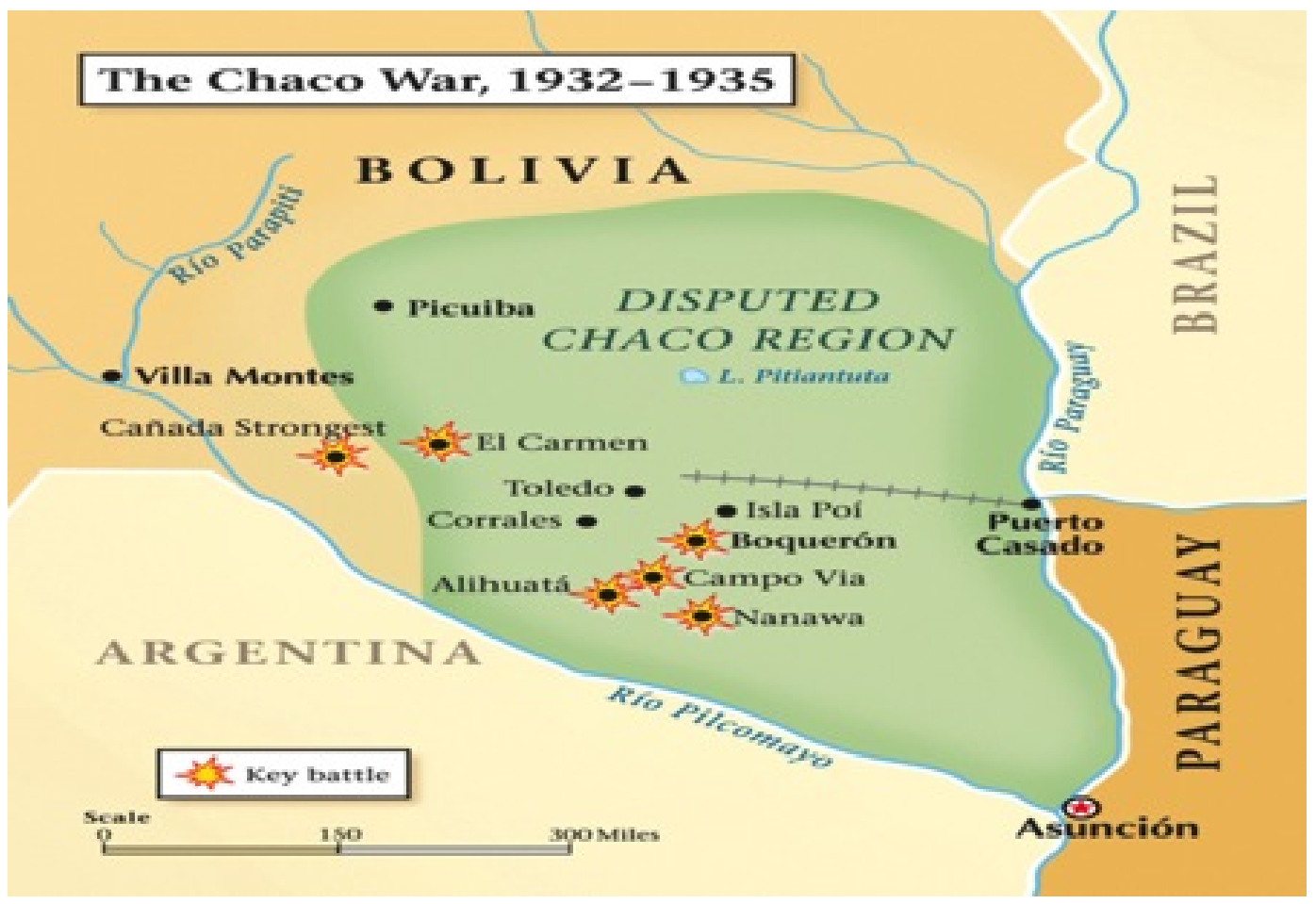

In 1946, Higinio Moríñigo lifted Paraguay’s ban on political parties and he formed a cabinet consisting of representatives from both major parties: the Liberals and the 
Colorados (Reds, the conservative party of Paraguay). By 1947, the Liberal Party left the arrangement, citing favoritism toward the Colorados and joined with other leftist elements in Paraguayan society to foment rebellion against Morínigo. The brief war lasted from March to August of 1947 with a victory for Morínigo that Alfredo Stroessner was instrumental in achieving, cementing conservative rule over the country for the foreseeable future. Seven years later, Stroessner took over the government from Morínigo prior to an intervention by two separate coups d'état. Paraguay's case retains the distinction of the longest rule by a single figure in continental history. Alfredo Stroessner Matiauda seized power in a 1954 coup d'état-cum-election in which he was the only candidate on the ballot. Vehemently anti-communist, Stroessner ruled Paraguay under self-granted state-of-siege powers akin to state of emergency powers that prop up dictatorships elsewhere, nominally legitimizing brutality. As President of Paraguay, Stroessner was extraordinarily violent in retaliation for dissent or political opposition, and maintained a firm grip on Paraguay’s governmental apparatus until he was removed by another military coup in 1989. Although he was repeatedly reelected for the duration of his tenure in office, Paraguay did not resemble a democracy in any real sense.

Uruguay's history during the negative peace period was similarly complicated. The rural/urban balance of Uruguay's politics remained tumultuous, with the Colorados representing the interests of Montevideo's commercial class and the Blancos (Whites) aiming to ply an agenda based on the commercial interests of the rural elite. After a brief civil conflict in 1904, normal politics had resumed, allowing the elected president to continue governing unchallenged. That president, a transformative figure in Uruguayan 
history, was José Batlle y Ordóñez who, during his two non-consecutive terms (19031907, 1911-1915) in office maintained an active, reform-minded policy agenda that included the addition of a plural executive, welfare programs, and significant government intervention in the economy. The years leading up to the great depression in the early 1930s were peaceful and relatively prosperous for Uruguay, as it had become a major shipping outpost for goods to and from Europe and its large, industrial neighbors in Argentina and Brazil.

The depression years saw an uptick in civil conflict between the government and people who sought a leftist response and an alternative in government to the two conservative ruling parties. As instability began to mount, the president, Gabriel Terra of the Colorados unilaterally dissolved government and began a rule-by-decree period that culminated in a new, heavily skewed constitution that delegated immense power to the president. The damage to the Uruguayan democracy was largely reversed by the election of Terra's brother-in law who, under pressure by labor unions and other center-left elements, advocated for liberal democratic freedoms and another new constitution to reflect those proposed changes. Problems in Uruguay would not resurface until the late 1960s, when commodity prices plummeted and sank the country into a period of deep instability. In response to rising unrest and in the face of protests and a burgeoning radical left (the Tupamaros, a significant guerrilla group), the sitting president called for a state of emergency in 1968, and four years later, severely curtailed civil liberties. The following year, the armed forces took control of the country with a civilian-military partnership government. The following twelve years would be known for the 
government's reprisals against the radical left: accounts of kidnapping, killing, politically-motivated imprisonment, and torture during the dictatorship period have been widely disseminated.

For the bulk of the 1970s, every country in the Southern Cone came under the control of authoritarian governance (with a brief respite in Argentina for the return of Juan Perón and his second wife, Isabel), and dissent was brutally retaliated against. In Argentina, the persecution of leftists was known as the Dirty War (La Guerra Sucia in Spanish), and thousands of people disappeared, were murdered or tortured by the government.

Chile came under the control of a military dictatorship, led by General Augusto Pinochet, in 1973 that was also known for its brutal tactics of repression. Despite the behavior of the dictatorship, the relationship between it and the Chilean people is a complicated one. The Pinochet years, particularly beginning in the late 1970s, were also known for a swift economic rebalancing and a long period of economic stability. Whatever the people's qualms about the military's tactics under Pinochet, there are many in Chile who remain loyal to the memories of his stewardship during the economic revival.

Alfredo Stroessner's iron grip on Paraguay survived the 1970s relatively untested. His loyal backing from the United States (until the Carter Administration) and other anticommunist forces made his rule formidable, and after two decades as president, his place at the head of Paraguayan politics was barely challenged domestically. Interestingly, as the next section will demonstrate, the incredibly rich history of rivalry and extraordinary violence in the region resulted in very little violent interstate conflict, and the little that there was, was not directed intraregionally. The long negative peace took place during a 
time of very unstable, non-democratic politics, and as will be seen in the section that follows, the period of stable peace began without uniform democracy in the region.

Stable Peace: Rapprochement in the Southern Cone, mid-1980s to mid-1990s

Relations between South American countries that had long been chilly began to thaw in the early 1980s. Brazil's public support for Argentina's territorial claim in the 1982 Falkland Islands War with the United Kingdom was a powerful signal that ArgentineBrazilian relations had moved toward rapprochement. However, the dual embarrassment of the lopsided loss to the United Kingdom in the Falklands War and a flagging economy with spiraling inflation led the Argentine junta to become the first among its Southern Cone counterparts to abdicate its role as leaders of the country in 1983, leaving democratically elected leader Raúl Alfonsín in a difficult lurch. The change in government, however chaotic, was also an opportunity. Argentina's new president began repairing damaged relations with Brazil and Chile, which both retained military dictatorships into 1985 and 1990, respectively. In 1984, Alfonsín moved quickly to sign a final and binding treaty to settle the Beagle Channel between the two long-conflicted neighbors while Pinochet's government was still beating back resistance in the midst of a depressed economy.

Argentina's rapprochement with Brazil was perhaps more impressive in retrospect, as Argentina had long viewed the Brazilian regime as an aggressive, expansionist one that threatened the states to its south and west (Kacowicz 2000b: 203). Contrarily, despite public support for Argentina's claims to the Falkland Islands (Islas Malvinas in Spanish), Argentina's behavior made Brazil's leadership nervous, and they also viewed Argentina's 
motives with suspicion (Kacowicz 2000b: 203). Shortly after, however, both countries began to align their policies and cooperate on the issue of nuclear proliferation, which would be a source of greater integration and goodwill between the two long-time rivals in the coming decades. By 1986, after both states had returned to democracy (although in Brazil only nominally until 1990) both states had begun to address greater economic cooperation by laying the foundations of Mercosur/l, a common market between Argentina and Brazil that became official in 1991 and has since expanded significantly. In 1990, the leaders of both countries met at perhaps their most famous border feature, Iguaçu Falls, to announce the Argentine-Brazilian Declaration on Common Nuclear Policy, formalizing the end of their quests to add nuclear arms to their respective arsenals (Kacowicz 2000: 203). The consolidation of peace between these two countries was further indicated by a dramatic increase in military cooperation, and the ArgentineBrazilian rivalry of centuries past faded into obscurity as a relic of a bygone era.

The 1984 agreement between Argentina and Chile on the persistent territorial dispute in the south turned out to be a watershed moment in the history of these two countries' relations. After nearly provoking war at least three times, claims to the Beagle Channel were settled and the two countries began interacting on a more cooperative basis (Kacowicz 2000b: 207). The return to full democracy in Chile was also met warmly in Argentina, resulting in a significant uptick in economic accords between the two countries. The former rivals agreed to the placement of a natural gas pipeline in 1990, and in 1991, settled 22 of their active border disputes through diplomacy while tripling 
bilateral trade (Kacowicz 2000b: 208). In Arie Kacowicz's estimation, stable peace “across the Andes has become an enduring reality.” (2000b: 208)

Uruguay's return to democracy also heralded significant change in the region, albeit with significantly less impact on power relations and enduring rivalries. By the time the Uruguayan military had returned power to political leaders, the unmitigated disaster of its political economy relegated thoughts of rivalry firmly to the backburner in succeeding decades. The traditionally bitter rivalry with Argentina from the nineteenth century receded in great measure, owing partly to ideologically aligned governments in the 1960s and 1970s and largely to Uruguay's pursuit of neutral foreign policy and a primarily domestic agenda. In any case, the return to democracy in 1985 made an obvious necessity out of positive relations with the neighbors on Uruguay's borders (Gillespie 1986: 195). Despite the enduring economic hardships of being embroiled squarely in the Latin American Debt Crisis of the 1980s, Uruguay's economy achieved a modest comeback throughout the early 1990s, as democracy was still regaining its footing. There had been occasional bouts with restive military elements during this period (Abente Brun and Danielson 2011: 546). By 1995, Uruguay had signed with Argentina and Brazil into the Mercosur project. Whatever its motives, Uruguay's rivalry with Argentina had all but disappeared during this period.

Paraguay's experience with democratization and integration with formal rivals was also a difficult one. After 34 years of unbroken rule, Alfredo Stroessner was pushed out of office by the same methods in which he accessed it. It should be noted that Paraguay had never truly experienced full-fledged democracy-the years between the War of the Triple 
Alliance and the advent of Morínigo were infamously turbulent, even within a Latin American context. The coups d'état of 1989 resulted in Paraguay's continued control by the military, albeit in a much more limited fashion. General Andrés Rodríguez, who replaced Stroessner, worked quickly to liberalize both the economy and the political arena, incorporating opposition politicians into positions of power, including positions on the Supreme Court and in the ambassadorial ranks (Abente Brun and Danielson 2011: 556).

Rather than repairing relations with Argentina, Chile, and Uruguay, the clear necessity for Paraguay's new leader was a matter of domestic political consolidation. Rodríguez set out to show the world that he was a committed reformer, meanwhile, within the domestic political landscape, he was tasked with upholding the last vestiges of power for the Colorado Party that had for so long controlled the country (Abente Brun and Danielson 2011: 556). Drafting a new constitution was also a high priority, but the agreed-to draft forbade reelection of any kind at the presidential level and prohibited General Rodríguez from running in the soon-to-be-held elections. Those loyal to Rodríguez hinted at another possible coups and he forswore the stipulations, but the elections went smoothly, and another president from the Colorado Party was elected with roughly 36 percent of the vote (Abente Brun and Danielson 2011: 557). The stable peace period in Paraguay should be viewed more through the lens of democratic consolidation and domestic concerns than as a matter of repairing damaged relations: since the War of the Triple Alliance, Paraguay has not instigated, nor been an active part, of any enduring rivalry within the Southern Cone. 
As a final installment to this assessment of the stable peace in the Southern Cone, Chile`s transition to democracy must be discussed on the grounds that it fundamentally altered good will and cooperation within the region. Chile's return to democracy was greeted with support by its neighbors and rivals, and President Patricio Aylwin, who replaced General Pinochet, began to repair not only the embattled economy but also Chile's damaged relations with other countries. As was stated here earlier, Chile's new government set about repairing relations with Argentina through increased economic, and later, military cooperation. Chile signed on to Mercosur/l in 1996, but chose to do so as an associate state, rather than the full membership that Argentina, Uruguay, and later, Paraguay preferred. Predictably however, Chile's main objectives were rooted in repairing its domestic situation, thus, whatever rapprochement existed was largely based in the economic sphere, rather than any overt gestures of political cooperation (such as the joining of binding regional organizations). It bears mentioning, certainly, that Chile's isolation limited the number of bilateral relations it could conduct. Thus, rapprochement with Paraguay and Uruguay was neither necessary nor possible, given the lack of antagonism between these three states. Conversely, relations with Argentina, Bolivia, and Peru were at the forefront of Chile’s diplomatic efforts over the next two decades.

Security Community? Integration and Cooperation Among Former Rivals, mid-1990s to the Present

The lack of war, combined with greatly diminished levels of negative rhetoric, since the mid-1990s have slowly changed the external perception of the international behavior of the Southern Cone states. Few states in South America were successful in escaping the 
specter of economic turmoil, but great strides were made in the 1990s towards changing the reputations and images of political behavior in the Southern Cone. As the 1990s progressed, a major development became clearer: a stable peace existed in the Southern Cone (Kacowicz 2000b; Oelsner 2005: loc. 3599). What of a security community? There are several authors who believe that a security community is forming (or has by now formed) in the Southern Cone. ${ }^{21}$ What can the events of the next nearly two decades demonstrate to test those claims?

As Argentina entered the mid-1990s, neoliberal economics would prove another test of the Argentine democracy's resiliency. The election of Carlos Saúl Menem to the presidency in 1989 was largely propelled by the deep sentiment of disappointment and distress among many Argentines whose comfortable lifestyles had spiraled chaotically downward as a result of the debt crisis that defined most of the 1980s (la Década Perdida, or the Lost Decade, is a recurring theme in the region's political economy). His election was largely built on the promise of a salariazo (significant wage increase in English) for every Argentine (Szusterman 2000: 199). As in most of its South American counterparts, taming the tiger of inflation was a persistent challenge in Argentina. Menem is widely thought to have pulled a 'bait and switch' with the Argentine public, installing the decidedly neoliberal 1991 Convertibility Plan which, when included with the subsequent waves of privatizing state industries, revaluing pensions, and reducing regulation and state spending, did not result in the promised salariazo in the short run (Szusterman 2000: 199). Whatever the macroeconomic benefits of the structural

\footnotetext{
${ }^{21}$ See Kacowicz 1998, 2000b; Hurrell 1998; Bodemer 2002; Flemes 2004, 2005; Oelsner 2005; Battaglino 2012.
} 
adjustment of the Argentine government's budget, the microeconomic consequences were acute and many Argentines again felt betrayed.

The initial years of the 1990s would prove a significant test for the Argentine democratic project, as well as its broader integration with the Southern Cone. Riots forced the early resignation of Raúl Alfonsín in 1989, handing the government to Carlos Menem earlier than expected. Shortly after Menem was installed as president, he set to work signing Argentina onto Mercosur and installing the Convertibility Plan in 1991. In the immediate aftermath, fortunes did not improve. However, buoyed by substantial economic growth in the latter years of his first presidential terms, Menem sought to challenge the Argentine constitution and run for reelection. Successful in his bid for a second term, Menem's motives were viewed with widespread suspicion, as reelections in the region typically accompanied propensities for holding onto power in the long term. During his second term, the economy's good fortunes began to reverse in tandem with a combination of a falling dollar and exorbitant external debt levels, and once again, Argentina descended into economic tailspin.

Fernando de la Rúa succeeded President Menem, taking office in 1999, and was immediately beset by the negative consequences of his predecessor's gamble on the Convertibility Plan. Democracy would again be tested in two years' time as the cacerolazo (a form of protest in which participants beat on pots and pans) began in the streets of Buenos Aires in response to crisis-level economic strain. Again, riots forced an Argentine president from office near the end of 2001, and as President de la Rúa was airlifted by helicopter away from the Argentine capital, riot police clashed with 
protesters, leaving as many as 12 dead. The next hours, days, and weeks provoked realistic fears of military intervention in a flailing government, but none was forthcoming. Argentina's democracy, however broken, remained in place, through a succession of interim presidents before finally arriving at the feet of Néstor Kirchner. One of his first moves as president was to antagonize his creditors by boldly declaring his intent to allow Argentina to default on its debts. Though this disqualified Argentina from participation in bond markets for the foreseeable future, it helped him to recoup public faith in government, and put no perceptible strain on its relations with its counterparts in the Southern Cone.

Argentina, like Brazil, was then buoyed out of morbid economic circumstances by the rise of the Chinese consumer thirst for raw goods, particularly beef, soy, and wheat, providing a significant windfall that would again elevate its economy in the short run, and allow Argentina to focus more intently on strengthening its ties within the Southern Cone and across South America. A notable exercise in Kirchner's political capital at the international level was his insistence on the formation of UNASUR in 2005. Modeled directly on the European Union (EU) in both structure and organizational aims, Kirchner sought to orchestrate an integrated South American customs union with political and defense prerogatives as well. Certainly, Latin America bears no shortage of international organizations with dubious efficacy, but the assent of the rest of (most of) South America's leaders to move forward with the project was symbolic not only of President Kirchner's personal credibility, but also of the regional perception of Argentina. The participation in UNASUR of all of the members of the Southern Cone, as well as 
Argentina's extraregional rivals, suggested the first clear sign of willful cooperation through common political institutions.

Uruguay followed a similar path to Argentina's after the restoration of democracy in the mid-1980s. The 1990s provided similar levels of up-and-down economics, thanks in large part to the same causative factors of overwhelming external debt and commodity price shocks. Accordingly, Uruguay reached the level of default in 2003, the year after Argentina had done the same. When Brazil, then Argentina's largest trading partner, devalued the real (its currency) in 1999, the shockwaves sent through the Argentine economy were immense, and the effects were lasting. Uruguay's dependence on Argentina as its largest trading partner, in tandem with Brazil's devaluation (Uruguay's number two trading partner), proved to be too much for the small, resource dependent economy across the Río de la Plata. The damage of Uruguay’s default however was limited by Uruguay's decision to pursue a different tack with its creditors. Uruguay's leader, President Jorge Batlle, had astutely chosen to negotiate a debt restructuring with its creditors. Because Uruguay pursued this path, it was able to rejuvenate its economy relatively quickly, continue to participate in bond markets, and embark on a path of sustained stability and growth.

The economic rebound in Uruguay was not quick enough for many in the Uruguayan public, and for the first time since the end of authoritarian governance, the conservative vise-like grip on the presidency came to an end. In what proved to be a significant test of Uruguay's democracy, its people for the first time voted for a Frente Amplio (Broad Front) candidate to assume the presidency. After having run for high office three times 
before, former Montevideo mayor Dr. Tabaré Vazquez was finally elected president without resistance from the traditional conservative political stalwarts who were generally resistant to the Frente's collection of leftist political parties. Many outside observers were sure that the Frente, once it got control of the presidency would revert to an idealistic socialist agenda.

Surprising most, President Vázquez chose to leave the economic prescriptions of the previous regimes in place, thereby playing a significant role in the resuscitation of a once-moribund economy. Vázquez also faced a test of military conflict during his first year in office. In response to protests over the pollution of an Uruguayan paper mill, Argentina's government chose to allow a civilian blockade of a binational bridge and to not prevent angry Argentines from boarding boat and threatening to cross into Uruguay (Mares 2012: 601). Uruguay's response was dispassionate, and the president elected to send troops to the border, although neither government advocated nor expected violent clashes. No violent confrontations were reported.

As Uruguay's economic recovery continued apace, the Frente Amplio was preparing its next candidate for the presidency, José 'Pepe’ Mujica, a former Tupamaro guerrilla, who campaigned on taking modest advantage of the windfall of a booming economy to boost investment in social programs targeted at improving the quality of life in Uruguay. Mujica's election in 2010 was symbolic of a fully rehabilitated and truly pluralistic democracy under no threat of interruption or interference from the military. Could Paraguay claim similar progress? Could Chile? Their experiences in the last two decades 
conclude this section of the chapter, and will serve to clarify whether a security community has developed in the Southern Cone.

Paraguay experienced more turbulence in the years during its democratic transition, although its relations with its neighbors, save one incident, remained stable and cooperative. After Juan Carlos Wasmosy was elected as president in 1993, Paraguay’s political trajectory seemed headed in the right direction, however by 1996, General Lino Oviedo sought to overthrow President Wasmosy and refused to be dismissed. Initially, the decision to terminate General Oviedo’s position with the Paraguayan Army was more shocking to many Paraguayan political observers, as Oviedo was widely thought to be a power behind the throne, so to speak. (Abente Brun and Danielson 2011: 557-558). Owing largely to swift international and popular rebukes of any attempt to de-legitimize the duly elected president, General Oviedo stepped down 24 hours later. Oviedo sought revenge at the ballot box in two years' time (Abente Brun and Danielson 2011: 558). As a consequence of mishandling the tense situation, Wasmosy allowed for Oviedo to participate in the Colorado Party’s next primary elections in 1998; after winning however, the Supreme Court ruled his candidacy ineligible and upheld a decade-long prison sentence levied against him for his role in the 1996 military mutiny (Abente Brun and Danielson 2011: 558). Consolidating democracy in Paraguay had, up to that point, proved exceedingly difficult.

The ugliness of violence in politics reared its ugly head again in Paraguay shortly after the fateful Supreme Court ruling. The candidate who ended up representing Oviedo's party began to explore options to allow him to assume power. Raúl Cubas, originally to 
be Oviedo's vice presidential running mate, ended up being impeached over the affair and his vice president was assassinated. Massive protests were met with state-sanctioned violence that left eight students dead, Cubas and Oviedo fled the country, and Paraguay was left in dire political and social straits internally. Following constitutional rules, the president of the congress served the rest of the presidential term, and in 2003, a legitimately elected candidate would assume the presidency. While resurrecting the economy was an ably conducted project for the new president's cabinet, Nicanor Duarte Frutos' presidency itself was marred by widespread corruption and attempts to reconfigure the constitution to allow him to run for reelection. Though Duarte Frutos did not succeed in his objective of reelection, his legacy remains a mixed one because of the positive economic advancement made in Paraguay and the contrasting political malfeasance. Until the presidency of Fernando Lugo, the twenty-first century had proved relatively quiet for Paraguay in terms of international relations and democratic consolidation.

Lugo was elected with an overwhelming majority in 2008, but his participation in a party of a weak coalition would doom his efficacy while leading the country, and ultimately prove to contribute to his political downfall. In international relations, he was a highly visible president who cultivated a wide swath of friends among Latin American leaders as the first leftist of any kind to represent Paraguay in the presidency. In 2008, he publicly accused Brazil of conducting military exercises at the border to coerce a favorable decision in particular bilateral matters (Mares 2012: 601). Certainly it is noteworthy, however, the incident had no bearing on the development of a security 
community among Southern Cone states. Finally, the incident with the most potential to destabilize the region came in 2012. As protests in rural Paraguay escalated to the point at which 17 farmers perished in clashes with police, the Paraguayan Assembly brought articles of impeachment to a vote; citing nepotism, insecurity, and political malfeasance (related to the deaths of the farmers), the Assembly quickly voted 76 to 1 in favor of impeachment. The following afternoon, Paraguay’s senate also voted overwhelmingly, 39 to 4 in favor of his impeachment. The Supreme Court ratified the decisions of both houses, and an assembly filled with political opponents of the president had succeeded in removing him from office. The aftermath entailed a broad call to deny recognition of the interim president, Federico Franco, and Mercosur suspended Paraguay pending new elections.

Argentina's refusal to recognize the Franco government has led to at least one diplomatic dispute over the construction of a nuclear reactor; however, Argentina has shown a willingness to cooperate with the newly elected government of Horacio Cartes. Fruitful and productive relations between the two countries of the Southern Cone continue without fear of violent conflict or territorial dispute. Chile's relationship with its neighbors has not suffered from a reversion to fear and suspicion among other Southern Cone states. General Pinochet, deposed as president had continued to serve in an official capacity as army chief of staff until 1998, and upon his retirement from that position, he chose to be appointed senator for life, refusing to retreat from public life (Skidmore and Smith 2005: 137). When he was arrested while visiting London later that year, Chile invoked his diplomatic immunity from prosecution rather than risk domestic unrest at 
home (the unrepentant Pinochet remained a powerful figure with the military and judiciary) (Skidmore and Smith 2005: 138). President Frei protected General Pinochet despite being of opposite political ideologies, and in his estimation, he saved Chile from potential backsliding to military dictatorship (Skidmore and Smith 2005: 138).

Chile's international relations since re-democratization within the region, and without, have also been exceedingly peaceful, in stark contrast with the war readiness that Chile often displayed during its dictatorship. In terms of external relations, Chile has increased military cooperation with its one time rival, Argentina, and committed to a joint force with them for UN missions (MercoPress 2010). Its economic pursuits have been less

muted. Since 2012, Chile has obtained a free-trade agreement with the United States and gained access to the prestigious Organization for Economic Cooperation and Development (OECD). In short, Chile's contribution to the zone of peace in the Southern Cone has been a clear aversion to notions of war and close cooperation with its traditional rival across the Andes.

\section{Testing Hypotheses in Light of the Historical Record}

In this section, I review my own hypotheses on the maintenance of the Southern Cone's zone peace vis-à-vis the facts accrued in the historical narrative presented earlier while also taking into account the explanations of venerable scholars on the matter. What follows is a direct recap of my own hypotheses followed by a brief discussion of how, or if, they appeared in the historical record of the Southern Cone’s zone of peace. 
1. A zone of peace is more likely to be maintained when the region is geographically isolated, thereby lowering strategic importance to great, or continental, powers, and presenting fewer opportunities for conflict.

That the Southern Cone is geographically isolated is not in doubt. Buffeted by the foreboding topographies of the world's driest desert (the Atacama) in Chile's north, and some of its least hospitable land (the Chaco) in Argentina's north and Paraguay's northwest, and separated from the rest of a continent by the Amazon Rain Forest, it can certainly be said that geography has lowered the opportunities for conflict. Conversely, however, similar geographical limitations exist in much of South America, making the prosecution of wars (particularly before the advent of air movements and paved roads) exceedingly difficult to consider for many South American countries. Although the Southern Cone was limited in its opportunities for war, so was the rest of its continent, likely explaining, at least in part, the comparatively small number of wars on the continent since the 1880s.

Contrasting this finding however is also a higher incidence of extraregional wars, among the Southern Cone's states. Among those three with natural ports and open access by water (Argentina, Chile, and Uruguay), the incidence of militarized conflict is higher than in Paraguay, which had little difficulty pursuing isolationism for much of its history. Chile’s major extraregional wars against Spain, and later, against allied Bolivia and Peru, were largely naval in nature. This had the advantage of cultivating a battle-experienced navy like no other on the continent and solidifying Chile's position as a continental power. Similarly, both Argentina dealt with blockades of their ports by the English, the 
Germans, and the Spanish. Additionally, it appears worth noting that the two countries with the least prohibitive geographies (Argentina and Uruguay) experienced the greatest amount of overland warfare, in terms of civil war or invasion.

Thus, it does appear that the benefit of geographic isolation benefitted most of the South American continent, as it is frequently noted for being peaceful. The extreme location on the continent does also appear to have limited its opportunity for conflict, although not more so than the continent as a whole, because most of the other countries face significant topographical obstacles to traditional overland war. Finally, the existence of good ports and open, navigable waters appears to have changed the nature and frequency of conflict between the Southern Cone and extraregional states, however, it does not appear to have had any effect on intraregional violence.

2. A zone of peace is more likely to be maintained when the states of a given region share a largely homogeneous ethnic and cultural makeup, thereby presenting fewer opportunities for conflict.

The ethnic makeup of the Southern Cone is largely homogenous, and made up of predominantly European peoples. In the case of Chile, the consolidation of its own terrain was difficult by land, so the native tribes were pacified as technology for prosecuting such a campaign became more available in the later nineteenth century, falling squarely in the negative peace period. Argentina's experience with its indigenous followed a similar course, although not one dictated by the difficulty of the terrain to the south of Buenos Aires. Contrarily, its pacification of the southern Chaco lasted over 60 years due to its reluctance to wage full-scale war in such inhospitable territory. In Uruguay, settlers 
had largely depleted what little indigenous population there was by the time the long peace set in, thus its likelihood for conflict along ethnic or racial lines was significantly lowered. By contrast, Paraguay’s first president mandated interracial marriages and prohibited the traditional caste system of the colonies from being enforced in his country. Accordingly, the incidence of mestizaje (a mixing of racial stock between European and Amerindian genes) is extraordinarily high, and white/indigenous relations are not typified by the same disruptions seen in Bolivia and Ecuador.

In one Southern Cone state-Uruguay-ethnic conflict during the zone of peace period is relatively muted. Argentina conducted a pacification campaign (Conquest of the Desert, 1770s-1884), like Chile (Pacification of Araucanía, 1861-1883) in the earliest years of the zone of peace. Argentina again militated against native peoples in the southern Chaco (within Argentine borders) and finally settled the matter after the conclusion of Paraguay’s Chaco War with Bolivia in 1938, but ethnic conflict outside of the eradication of the indigenous tribes usually manifested itself in small-scale protests over new waves of immigrants arriving Buenos Aires at the turn of the twentieth century. Chile's pacification conflict was a direct military conflict waged by the central government against the resistant tribes in the south of the country, but it was the only one of its kind. Occasional problems with indigenous communities still occur, but certainly not at a level that would be considered violent conflict. Finally, Paraguay’s approach to high levels of diversity from the very first days of its independence likely served to lower the propensity for conflict on ethnic lines, although Paraguay was one of the most violenceprone states (if not the most) in the study. Violence in Paraguay does appear to be 
correspondent with its role as the most ethnically heterogeneous, however when judged by the historical record, the likelihood of a correlation appears insignificant. The record on ethnic makeup and conflict likelihood, in terms of causation, is mixed in the Southern Cone, but the raw connection between the two is readily apparent.

3. A zone of peace is more likely to be maintained when the region's decision makers are bound to opt out of conflictual outcomes by their preference structures, thereby lessening opportunity for conflict. AND/OR

4. A zone of peace is more likely to be maintained when the region's political culture is characterized by preferences for restraint from decision makers.

Does a culturally accepted preference for peace, or violence, reflect itself in the decisions of the Southern Cone's leaders? Are the decisions they make products of the values imbued in the cultures they hail from? Are their relations with their regional counterparts colored by prevailing opinions about them?

In the Southern Cone example, this hypothesis appeared to have little bearing whatever on the decisions of leaders to go to war with other states in the region or elsewhere. During times of peace, political leaders (often dictators or military juntas) seemed more reined in by their own assessments of capabilities for victory or difficult logistics. Perhaps, however, it is worth exploring the relationship between the preference structures of the democratic leadership of these countries and the incidence of war. It appears that the leaders of Southern Cone states explicitly pursue policies with the avoidance of war, and have, in recent years, been vocal in their attempts to assert a zone of peace. In the case of the Southern Cone, this stipulation appears to have a greater correlation than 
those preceding it and might be better applied to a security community situation only (stable peace was shown to be tenable without uniform democratic governance).

\section{A zone of peace is more likely to be maintained where interdependence and common} political institutions contribute to the formation of a security community.

The evidence is not perfectly clear in the historical record with regard to this hypothesis. To be sure, the deepening of democracy hailed more peaceful relationships between longtime rivals in the Southern Cone, and the speed of economic integration picked up exponentially between the Southern Cone countries in the wake of their respective authoritarian experiences. Certainly, relations have been more peaceful since the advent of Mercosur, and more prosperous since the gestational phases of UNASUR in 2005, and the trajectory of regional relations appears clearly to be headed towards greater cooperation and deeper peace.

As was noted earlier in the chapter, the willingness to cooperate on UNASUR signaled that perceptions of Argentina, or any other state in the Southern Cone, were firmly placed in the past, but is this change in perception because of greater independence or is the relationship the inverse? The qualitative analysis presented here does note definitively answer that question. Contrarily however, when viewed over the totality of the zone of peace period, from 1870 to the present, the upward trajectory of regional institutionalization has roughly mirrored that of political opening and zone of peace maturation. Importantly, the peace of the Southern Cone is undoubtedly less precarious now than it was during the stable peace and negative peace periods, and the Paraguay example shows a willingness to mete out punishment through political institutions rather 
than to declare war. I can comfortably assert a highly probabilistic relationship between the levels of institutionalization and/or common political institutions and more certain peace in the Southern Cone.

6. A zone of peace is more likely to be maintained when there is broad 'satisfaction with the territorial status quo' among the region's states.

Particularly viewed through the lens of the most major rivalry in the region, that of Argentina and Chile, relations were obviously at their most adversarial when the question of territorial control was raised. The last war fought by Paraguay outside of its own borders was the War of the Triple Alliance-a war waged by Paraguay to claim territory in Argentina, Brazil, and Uruguay. It is worth noting that its external relations have been devoid of war ever since. Argentina's participation in wars has been almost exclusively dedicated to the prosecution of territorial claims against regional foes, and during the time of the zone of peace, against extraregional enemies. Uruguay's history of war tracks similarly to that of the others: outside of territorial disputes, war was nonexistent in Uruguay. After the zone of peace period commenced, Uruguay's only involvement in war was initiated in the final months of World War II. Unquestionably, the Southern Cone's zone of peace was bolstered in both the short and long runs by the settlement of territorial disputes.

\section{Conclusions: Assessing the Southern Cone Zone of Peace}

This chapter concludes with a concise assessment of the Southern Cone’s credentials as a zone of peace, followed by a brief review of the results from the hypotheses offered 
earlier and attempts to provide some context for this study ahead of the concluding chapter.

First, regarding the Southern Cone's qualification as a true zone of peace, the historical record appears clear that by the standards of (1) being devoid of intraregional interstate violence and (2) being bereft of international wars with extraregional states outside of self-defense, the region acquits itself well. Those two minimum standards for the designation of a negative zone of peace are certainly fitting for the period between 1870 and the present. After the Paraguayan War concluded in 1870, war has been a phenomenal occurrence in the region, occurring only rarely, and not at all between regional counterparts.

Second, the designation of a stable peace necessarily entails (3) the lack of civil war or armed uprisings on a large scale; and (4) few military interventions in the affairs of another state outside of internationally sanctioned actions. The historical record is also exceedingly clear on when the Southern Cone met these standards. By the mid-1980s, the dissolution of military governments in Argentina and Uruguay result in the end of long struggles by leftists to battle their dictatorships. Chile, continued to deal with dissidents in an unsavory manner until the latest years of the 1980s, as did Alfredo Stroessner, but armed uprisings had largely dissipated, and neither country was in the midst of a civil war. To eliminate the civil war and armed uprisings stipulation entirely from the rubric of the Southern Cone, one could classify the onset of stable peace as occurring no earlier than 1989-1990. 
Military interventions by most of the Southern Cone’s states were relatively limited even during the negative peace period. Chile's record of persecuting leftist activists, more often than not, extended beyond its own borders, however those were not state-on-state acts of aggression, rather, they were renderings conducted on sovereign territory. In any case, the number of military interventions in other states' affairs certainly diminished to near zero by the early 1980s. On this, the historical record is fairly clear. Rarely did any of the states in the region send their troops far afield to assist or to help topple another sovereign state.

Finally, testing for the presence of a security community in any region, regardless of location, begins with (5) an expectation that numbers 1 through 4 above will not occur, or are extremely unlikely; and (6) the states in the region share common political institutions and democracy, and are heavily interdependent. It seems abundantly clear that the expectation of a recurrence of war in South America as a whole, and particularly among the members of the Southern Cone states ranges between exceedingly low and nonexistent. As integration proceeds apace between these states through institutions such as Mercosur, UNASUR, CELAC, and to a lesser extent the Organization of American States (OAS), the number of disputes that are likely to be solved by war are infinitesimally few if there are any at all. The common political institutions stipulation is a little ambiguous, yet it is clear that all the countries of the Southern Cone remain committed to vibrant democracies, despite some differences in political practice (particularly in Argentina). Finally, interdependence of the heavy kind is difficult to define in clearly delimited terms, but a deep vein of cooperation runs through these states 
(with the exception of Paraguay's interim government of 2012-2013, toward which feelings were negative), and each ranks highly on all the others' lists of most prolific trading partners.

Reviewing the results of the study conducted above, some surprising facts became clear. At the onset of the negative peace in 1870, long, biter rivalries between some countries virtually disappeared, with only one main rivalry dominating the international relations landscape within the region over the next century. The relationship between Argentina and Uruguay was exceedingly violent and bitter during the post-independence decades, as Argentina's quest to bring its provinces (which for a time included Uruguay) under control occupied a great deal of its military agenda. As a result, a constant strain of interference and proxy conflict marred the two countries' relationship. At the conclusion of the Paraguayan War in 1870, the tendency toward combat between the two countries virtually disappeared. The Paraguayan War was similarly pivotal in the external relations of the country at the center of the conflict. Never again did Paraguay engage Argentina or Uruguay in violent conflict, and exceedingly rare was any type of conflict at all.

The relatively warm relations between the countries of the Southern Cone that became visible at the onset of the stable peace period appeared to make the beginning of what Charles Kupchan refers to as the "generation of new narratives and identities" (2010a,b). Andrea Oelsner notes the same phenomenon of the change from 'neighbor as rival' to 'neighbor as partner' (2005: loc. 3608). The onset of stable peace was also characterized by an atypical grouping of regimes. The warming of Argentine-Brazilian, and ArgentineChilean relations, began in the waning days of each country's dictatorship and during the 
transition to democracy for one, while the other was still firmly under the grip of dictatorship, respectively. Unquestionably, the onset of full democracy in both Argentina and Chile provoked the president of each country to, without acrimony, call for comprehensive and immediate resolution to the two countries' 22 remaining border disputes. Similarly, the negotiation and groundwork phases of Mercosur remained effective despite the Brazilian president’s perceived lack of legitimacy. ${ }^{22}$

This research spent a great deal of time discussing the history of the Southern Cone with aims of discovering whether the hypotheses formulated earlier in this research were visible in the case of the Southern Cone and thus, worth repeating as generalizations for use in other zones of peace analysis. An additional focus of this chapter was to assess the importance of democracy in developing a negative zone of peace into a pluralistic security community. In both respects, this study has managed to answer the questions ably. Regarding my hypotheses about peace in the Southern Cone, of the six, three were highly accurate, while three more were either inconclusive or shown to have little bearing on the maintenance of peace in the region. Conversely, the role of democracy in deepening the peace process, and securing it for the long run, was shown clearly here. In the Southern Cone's case, democracy had a clear relationship with the maturation of a negative, precarious zone of peace into a positive, stable one, and beyond that, into a pluralistic security community. Deeper analysis will be necessary to understand where

\footnotetext{
22 José Sarney, Brazil's president from 1985-1990, was viewed as sympathetic to the outgoing military regime, and he was an interim president. He replaced the president-elect, Tancredo Neves, as Neves died shortly before being installed as President of Brazil. His status as an interim president lowered his standing in the eyes of many in Brazil's congress.
} 
along the Adler and Barnett typology the Southern Cone security community falls, but it certainly meets the minimum standards of nascence.

The chapter that follows seeks to compare the results of this chapter with those of the last. In Chapter IV, I make some generalizations about zones of peace based on these results, and I make some suggestions for further refinement of the zones of peace approach and some potential points of departure for future avenues of research within peace studies. 


\section{THE NORDIC AREA AND THE SOUTHERN CONE IN COMPARATIVE}

\section{PERSPECTIVE}

After reviewing the zones of peace in the Nordic area and the Southern Cone, this concluding chapter compares these two regions along two thematic lines: their qualifications as distinct zones of peace and their relationships to the six generalizations about regional peace detailed in the three previous chapters. The comparison fielded in the pages that follow challenges the frequently proclaimed exceptionalism of the Nordic area and leads to conclusions that can not only clarify a broader understanding of how zones of peace have been maintained in the Nordic area and the Southern Cone, but also help shape frameworks for understanding regional peace going forward-wherever they may occur. Because many of the world's developing states are located in zones of negative peace, this study provides ground for cautious optimism that the lessons learned here might be useful in shepherding conflicted, developing regions toward more fruitful, stable peace.

This chapter proceeds by comparing the results of the research conducted in earlier chapters. First, I assess the credentials for each section as a zone of peace, and through this analysis, I discover what differentiates them within this distinction. That is, although both are established in earlier chapters as true zones of peace, the following pages help to add nuance to the differences between the Nordic states and those of the Southern Cone. Second, I examine how well the existing explanations for peace in the Nordic area, and the attendant hypotheses about the existence of peace elsewhere (in this case, tested 
against the experience of the Southern Cone), fared in light of the historical accounts presented in the preceding chapters.

Because the comparative dimension is the crux of this research, the results discussed here undergird inferences in important empirical and theoretical areas for peace research elsewhere. From an empirical standpoint, this study (like others before it) acknowledges the obvious value of knowing the necessary, favorable, and permissive conditions for long-term peace. The conclusions presented here further a long-standing goal in peace studies of better understanding what it takes to achieve peace at the increasingly important regional or sub-systemic level. Theoretically, the saliency of the conclusions in this chapter is derived from adding to the body of literature by offering viable examples of the Nordic area and the Southern Cone as distinct from their more often studied larger continents. To that end, this research reveals some potential weaknesses in existing approaches to zones of peace studies and suggests potential refinements and important avenues for new research in comparative zones of peace analyses.

\section{Comparing Diverse Zones of Peace}

This section offers several comparisons among zones of peace on opposite ends of the world, and it should be viewed as unfolding in two parts. First, the study proceeds with a direct comparison between the Nordic area and Southern Cone zones of peace; assessing first their respective qualifications as zones of peace, and later, security communities. What follows is a brief discussion on the effects of democracy, or its absence, on the quality of peace in each regional history, with specific emphasis on the period after the

onset of negative peace. The next part of this section examines peace in each region in 
relation to the explanations for peace tested in Chapters II and III. A recap follows of each explanation-cum-hypothesis for peace and the results of each chapter's research related to them. Along the lines of these six explanations for peace, a direct comparison is made between the Nordic area and the Southern Cone, and a concise picture is made clear of their similarities, as well as points at which they diverge, in the management of their respective long periods of peace.

The Nordic Area and the Southern Cone: Commonalities and Divergences as Zones of Peace

The two major case studies explored in this book are those of very different regions in the developed and developing worlds that have experienced long periods of international peace. In the Nordic area, there is a well-established and broadly recognized (some argue paradigmatic) peace that has evolved into the world's foremost example of security community. In South America, the arc of its complicated peace extends for more than a century, encompassing different levels or gradations of regional peace: from negative peace to stable peace to the emergence of a nascent pluralistic security community in the Southern Cone.

The research in Chapter II confirms a recurring theme in peace research: that of the Nordic area as a zone of peace. Chapter III serves to distinguish, and confirm, the Southern Cone as a distinct zone of peace apart from the more often cited South American continent. The dual conditions of little or no war in the region, either between the region's states or with those outside it, were satisfied in both regions and at minimum, a negative zone of peace has been established in each for more than a century. Having 
been last touched by intraregional war in 1814, the Nordic area has managed to totally avoid militarized responses as a means to conflict resolution within its own borders. Moreover, the Nordic region's experience with militating against extraregional states is also extremely limited, and where present, is most often the result of extraregional incursion. None of the Nordic states has pursued a war of choice since the 1864 conclusion of the Second War of the Schleswig, in which Denmark fought to retain territory south of its traditional borders. The Southern Cone has also managed to avoid war among its own states since the conclusion of the Paraguayan War in 1870. The region has known war since 1870, but it is both rare and exclusively civil or extraregional in nature. Each region's history as a zone of peace is predominantly dictated by this tense, negative peace period, wherein suspicion remained as warlike behavior within the region dissipated for roughly a century.

The research in Chapters II and III did highlight two interesting commonalities between the Nordic area and the Southern Cone states: first, each did clearly achieve stable peace, although the movement toward it was chronologically difficult to identify; second, the stable, positive peace phase was the shortest-lived iteration of the zone of peace for both regions. The second of three progressive gradations, the stable zone of peace is defined by two principle stipulations that there be minimal armed conflict in a region manifesting itself as a civil uprising or war and that military interventionism-apart from internationally-backed actions-be minimal or nonexistent. Charles Kupchan adds that stable peace emanates from the presence of institutionalized restraint on decision makers, increased interactions between states, the generation of new identities, and primarily, a 
unilateral act of accommodation (2010b: 6). The stable gradation is the critical juncture in the maturation of a zone of peace in which war ceases to be a preferred, or legitimized, tool of statecraft among interacting and intertwined states. Considering the difficulty and intricacy of the construction of a zone of stable peace, it is perhaps unsurprising that-at least in the two cases analyzed here-this level of peace was not reached for more than a century.

The Nordic area is often thought to have reached stable peace much earlier than it did (Deutsch and his colleagues [1957] assert that a security community was formed in 1905), if one accepts the above metrics as valid. Stable peace was not established in the Nordic area as a direct result of Sweden's decision not to pursue war to reclaim a newly independent Norway. This research shows that this particular historical event was but a first step on the path to deeper peace within the region. War plans between Norway and Sweden did not disappear in the wake of the Norway's independence, but rather remained firmly at the tops of both countries' security agendas until about 1930. Moreover, civil war was far from unknown in the region; particularly as Finland aimed to assert its independence from Russia after the overthrow of the Russian Empire. Finland's Civil War in 1918 was a notable example of civil war during the Nordic peace period, although it was the only such instance, and a lack of further occurrences helps to solidify claims of a stable peace in the Nordic area. Finally, the Nordic states have remained largely absent militarily in foreign affairs; those interventions that do exist in their histories are rare and solely as a part of sanctioned international actions. 
The Southern Cone's accession to the stable peace rung within zones of peace appears, at first, more problematic. Military intervention in other countries without international backing has been non-existent during the peace period since 1870, but civil wars and/or armed uprisings are infamously recurring issues in the region. It is important to point out however that every one of the Southern Cone's four states did overcome these periods of spectacular internal violence, and armed uprisings are today exceedingly rare or nonexistent. (Paraguay has had some recent skirmishes with a small, rural segment of violent anti-government groups, but it would be difficult to characterize them as an armed uprising.) As a result of the third wave of democratization, a return to democratic governance in the Southern Cone has served to speed the pace of economic integration and more trustful relations within the region while putting a stop to the armed rebellions against the now-deposed military governments. Stable peace began to form in the Southern Cone in the mid-1980s after more than 100 years of internal violence and precarious intraregional relations.

\section{The Nordic Area and the Southern Cone: Evidence of Security Communities?}

Related to the stable peace discussion in the preceding paragraphs is the development of the third gradation of a zone of peace: security community. At the point where a region has reached security community, there should be little or no expectation of the types of violence already specified here, but there should also exist a framework for interdependence, characterized by economic and political conformity. Within a security community, the common political paradigm is democracy, and the states of the region often agree to be bound by norms and laws that govern their interactions, such as customs 
or security cooperation. Within the security community designation, Emmanuel Adler and Michael Barnett have added three additional gradations: nascent, ascendant, and mature (1998). Each of these stages is defined by specific characteristics that help to identify the point at which a potential case lies on the aforementioned continuum.

\section{The Nordic Area and the Southern Cone as Nascent Security Communities}

Accepting Adler and Barnett's definition of nascent security communities entails the formation of a security community without explicit intent. Rather, the opening stages of security community development are typified by interaction designed to decrease transaction costs and foster the beginnings of mutual trust (e.g., diplomatic, economic, bior multilateral exchanges) (Adler and Barnett 1998: 50). This process was identifiable in the Southern Cone within a decade of crossing the stable peace threshold, as the fall of the dictatorship in Chile in 1990 sped up economic and diplomatic cooperation between long-time rivals in Argentina and its neighbor to the west. Uruguay’s return to democracy in the mid-1980s began a political and economic liberalization period that saw it increase its economic ties with its major regional rival, Argentina, in a move to buoy a flagging economy. In 1989, the end of the Stroessner dictatorship in Paraguay meant an opening begat by a similar liberalization of the formerly isolationist state's international relations. Early attempts from new governments in Asunción, Buenos Aires, Montevideo, and Santiago to improve economic and intergovernmental ties moved the region quickly from stable peace to nascent security community.

The shift from stable peace to nascent security community was also relatively speedy in the Nordic case. The amount of time spent in the stable peace period was markedly 
shorter than that spent as a negative zone of peace. Between the cessation of hostilities within the region in 1814, and the beginnings of closer cooperation and shifting perceptions in the 1920s (and to a lesser extent, in the latter years of the decade before) there existed over a century of clearly identifiable negative peace. As the former rivals began to establish a pattern of closer ties through cooperation, most notably under the auspices of the Nordic Association, plans for war between them gradually began to fall off each state's security agenda. As the process of rapprochement between former warring factions gained momentum, the Second World War halted any formal processes of integration. Shortly after the war's conclusion however, the groundwork was laid for the flourishing and pluralistic security community visible today in the Nordic states. The nascent phase of security community was clear in Norden after a roughly 15-year period as a stable zone of peace. Close cooperation immediately after the war's end roughly demarcates the Nordic area's transition to a nascent security community, as talks among Nordic leaders led to formalized cooperation within two years.

\section{The Nordic Area and the Southern Cone as Ascendant Security Communities}

Movement from nascence to ascendance in the Southern Cone security community was, like many of these other important shifts, a process that evolved relatively rapidly. Characterized by Adler and Barnett as "increasingly dense networks" and the development of formalized economic and security ties that display the disappearance of threat perceptions between states, an ascendant security community in the Southern Cone was taking hold by the mid-1990s. Paraguay and Uruguay joined its Southern Cone counterpart, Argentina, in Mercosur, while Chile obtained associate member status to the 
trading bloc in 1996. The advent of Mercosur symbolized a deepening and formalizing of economic and, later, political ties between the formerly uneasy states. At this point, one can assert firmly that the roots of an extensive network of cooperation begin to take form. By the mid-1990s, the historical record makes clear that the thought of war within the Southern Cone was a distant memory-this is evidenced by the amount of cooperation dyadic, particularly on nuclear proliferation.

The Nordic area's ascendant phase was made similarly clear through the development of the Nordic Council. Although Finland's proximity to the Soviet Union and Sweden's abject adherence to neutrality in conflict scuttled discussions of a formalized, pan-Nordic security agreement, a framework for deepened ties and greater cooperation came about in 1952, as the Nordic Council came to fruition. Indeed, it appears that any fears of intraNordic war or otherwise militarized conflict had faded before the Second World War, and the identification of a common threat in the Soviet Union helped to deepen dependence on coordination measures within the region. The early years of the Cold War period in Norden were typified by a strengthening of the Nordic identity and closer relations between each Nordic state. Nordic states also began to be acknowledged for their singular levels of cooperation by being dealt with as a bloc in the UN, rather than individual countries, signifying tighter cooperative patterns at the international level.

\section{The Nordic Area and the Southern Cone as Mature Security Communities}

The third and final phase of security community-mature-is representative of interstate, intraregional relations at their cooperative apogee. By the maturity phase, the region adopts an identity and each state views its counterparts as solely peaceful agents of 
change. For the members of any mature security community, interstate relations have moved beyond purely instrumental motives, and preparations for war among each other are non-existent. Diplomacy and negotiation are accepted as a norm of international relations within the region. For those scholars who view security community as a binary, not gradient, condition; these tenets are the manifestation of this type of zone of peace. Similarly, Adler and Barnett make clear that maturity is the only stage at which a true security community emerges (1998: 55).

Among mature security communities however, Adler and Barnett identify two variants that prove a useful conceptual cleavage when considering the cases of the Nordic area and the Southern Cone. A loosely-coupled security community is identified by the following hallmarks: mutually positive identification and a shared claim to a way of life; many and varied modes of interaction that undergird the security community; a shared system of behavioral norms in the international realm, if not governance; and an expectation that despite conflicts and asymmetries, states will exercise restraint in their dealings with one another (Adler and Barnett 1998: 55). Conversely, a tightly-coupled security community is a variant that includes all of the above qualities, but deepens cooperation in some key areas not necessarily covered by the first, loosely-coupled variant, they are: cooperative and collective security; military integration at an advanced level such that security is deemed an interdependent matter; unified policy on internal threats; free movement of peoples; supranational bodies of legitimate authority; and a multiperspectival polity, wherein compatible values allow for rule to be equally valid at the national and regional levels. 
Based on the qualifications listed here, each region's security community designation appears ambiguous. While both retain significant elements of mature security communities of both types, neither the Nordic area nor the Southern Cone examples of security fit neatly into one variant category or another within the mature security community gradation. By the standards set out by Adler and Barnett, both the Nordic area and the Southern Cone qualify as mature security communities based on the research conducted in this study (1998). The Southern Cone's affiliation with international institutions might however be seen as problematic for such a designation. Although it does achieve transnational institutionalization and a common identity, as well as a broad set of common norms (e.g., Mercosur's Ushuaia Protocol, which specifies that members must adhere to certain democratic principles lest they be suspended or expelled from the bloc), it does so through regional organizations that are broader in scope than the states of the Southern Cone alone. Thus, distinguishing the Southern Cone as apart from South America in this sense proves difficult. In the purest sense of mature security community however, wherein regional actors no longer have any expectation of war among each other and share a common purpose in the international arena (loosely interpreted as identity) this research shows that the Southern Cone indeed fits the model, if only recently.

Unexpectedly, the Nordic area does not neatly fit the criteria for the highest form of mature security community (tightly-coupled). As its example is held up as a Paradigmatic zone of peace, and perhaps the world's only extant and uniformly acknowledged security community, the lack of some key elements of a tightly-coupled, mature security 
community proved surprising. Its lack of uniform security policy and military integration bars it from entry into Adler and Barnett's highest class of security community. However, the achievements of the Nordic peace should not be understated. Differently from the Southern Cone, the regional identity of the Nordic states is unambiguous, and the region clings strongly to a communal Nordic identity. Additionally, the Nordic area has long availed itself of a policy of free movement of peoples among its states, an artifact of tightly-coupled security communities that the Southern Cone states also share, albeit through the larger, continental UNASUR configuration.

In any case, determining the precise placement of the Nordic area and the Southern Cone on the continuum within security communities proves difficult, however, it is clear that both regions were accurately proclaimed to be (1) zones of peace; and (2) security communities. Comparing each region along the lines of core tenets of zone of peace gradations does yield some interesting answers to questions that this research sought to answer, but there are still more that must be considered before this comparison can be considered complete, or at minimum, thorough. A core question driving this research, the effect of democracy on each region's movement along the aforementioned continuum, has yet to be discussed in comparative perspective. What follows is a brief discussion on the role democracy did, or did not, play in each region as their respective zones of peace developed.

Accounting for Change: Democracy in Norden and the Southern Cone

Democracy, as defined in preceding chapters, was a relatively late addition to the Nordic area and Southern Cone experiences. Although Norden is often thought of as, at least 
colloquially, a grouping of the world's oldest and best developed democracies, there exists considerable debate over when the Nordic states uniformly enjoyed full participatory democracy. The Southern Cone's states, on the other hand, have had a clearer relationship with the political democracy delineated in Chapter I. To that end, the later development of political democracy in Norden also appears to correspond to the advent of fully stable peace in the region. The region's two major powers, Denmark and Sweden, were the last to minimize the roles of the more conservative, royalist factions in parliamentary leadership that allowed them to fully liberalize their foreign policy portfolios. Denmark's 1920 Easter Crisis and the developments of the late 1920s in Sweden track neatly with the growth of stable peace among the Nordics, as Iceland, Finland, and Norway had all by that point successfully consolidated their democracies.

The advent of stable peace in the Southern Cone began as the region's countries either reor newly democratized. The broader, fuller participation of the public in accountable electoral processes deepened in the region as the 1990s wore on, and by the mid-2000s, the results of these democratic reforms were instrumental in moving the region from its short stable peace to the security community that is visible today.

\section{The Nordic Area and Democracy: Balancing a Monarchy}

The Nordics began their peace period as an amalgamation of democratic institutions and monarchies still clinging to power, particularly in matters of foreign policy. For more than a century following the last war in the region, each of the Nordic states would have 
to carve out their own paths to democracy while dealing with questions of monarchy. ${ }^{23}$ It is partly because of the way that these shifts were handled by the Nordic states that regional peace became so noteworthy. Unlike the case in the Southern Cone however, the movement along the zone of peace continuum from stable peace to security community would not be nearly as determined by this challenge as the change from the status quo of negative peace to a cooperative, stable one. Over a period of 30 to 40 years, each of the Nordic states would find a non-violent way to either break with long-sitting monarchs or to redefine and reshape the roles of the monarchs in national and international politics, fundamentally enriching the quality of regional peace.

Negative peace began after the conclusion of the Swedish campaign to reclaim its recently gained territory of Norway in August of $1814 . .^{24}$ As the Napoleonic Wars diminished most of Europe’s territorial claims, the Swedish Empire saw the reclamation of Norway as essential after the loss of Finland to Russia. The Danes took a similar approach some decades later to the Schleswig and Holstein provinces between Danish and German territories. The experiences of both proved instructive for the two former 'colonial master' states of the Nordic region in the latter decades of the negative peace period. Deciding the fate of Norway after it unilaterally dissolved its union with Sweden was a difficult process, as conservative members of parliament and royal decision makers

\footnotetext{
${ }^{23}$ It is often overlooked that Finland's independence from the Soviet Union was declared in 1917. The parliament voted to establish a constitutional monarchy (Kingdom of Finland), although this project was sort-lived because of the fall of the German Empire, from which newly-independent Finland's monarch had been expected to hail.

${ }^{24}$ Sweden received the territory of Norway from Denmark in January 1814 as a result of the Treaty of Kiel. The former had allied with Russia while the latter had allied with France, resulting in Denmark-Norway's defeat along with Napoleonic forces.
} 
pushed for a war to reign in the Norwegians. Similarly, King Christian X of Denmark was displeased by the results of the Schleswig and Holstein referenda, and he pushed for a military campaign to reclaim it in 1920. In each case, monarchy's traditional power emerged diminished in its capability to decide foreign policy, particularly in matters of war. The Icelandic relationship with Denmark also provides a case of significant remanding of royal power to democratic leadership, as Iceland's parliament was able to gain near-total autonomy through a negotiated 25-year agreement with the Danish Crown that would end in a referendum on Danish rule over the island nation.

Stable peace began to sweep through the Nordics as the 1920s progressed, after more than 100 years of tense, suspicious relations. As war plans were reconfigured and coordination between Nordic governments improved, a clear change had set in: none of the monarchs had unilateral power to view their international relations as games of empire. Cooperative relations in the 1920s and 1930s were sped along by the diminishment of royal power and the recognition of common threats from the Nazis and the Soviets. With power structures reshaped in the region, dispute resolution came through diplomatic negotiation and impartial arbitration and was no longer viewed with embarrassment by a royal power hoping to save face. ${ }^{25}$ The correlation between firmer commitments to peace and changes in governance structures shows a clear correspondence is visible through the examination of the historical record. The Nordic example lends credibility to arguments that democracy is not a necessary condition for

\footnotetext{
${ }^{25}$ Both Denmark's and Sweden's monarchs were, according to historical accounts, reputedly affected in this way by the Norwegian dissolution of its union with Sweden in 1905 and the results of the referenda in the Schleswig-Holstein provinces in the 1920.
} 
peace, but also to arguments that recognize its positive relationship with stable peace and security community.

\section{The Southern Cone and the Third Wave of Democratization}

The earlier iterations of democracy in the Southern Cone were, like many democratic governments of the period, largely nominal. The first elected president of the Argentine Republic was the first in a string of oligarchic rulers occupying the Casa Rosada (Pink House, the Argentine presidential palace) not broken until two decades after its founding, when the Radical Civic Union (UCR) won the presidency in 1916. A brief golden age was interrupted in 1930 by the beginning of 50-plus years of political vacillation between military rule and extraordinarily weak or ineffectual presidencies. The other countries of the Southern Cone, except for Chile, followed a similar wave of uncertain or nonexistent democracy into the 1980s, when the tide of authoritarian regimes in South America began to recede. Among the Southern Cone countries, Argentina’s military rule was the first to end in 1983. Uruguay's followed shortly thereafter, in 1985. The re-democratization period in these countries marked effective building blocks for a stable peace among the Southern Cone nations that followed. These newly democratic governments were eager to speed along integration in the face of floundering national economies. The advent of democracy in Argentina also began a precipitous thawing in relations with its neighbors, despite diverging modes of governance.

The last two authoritarian regimes in the Southern Cone, those of Chile and Paraguay, were among the last two of their kind in the Americas, and were also beset by grave economic troubles as a result of the broader Latin American Debt Crisis. The case of 
Chile is somewhat exceptional in Latin America in that its democracy had strong foundations from the country's inception until 1973, when a September 11 coups d'état led by General Augusto Pinochet toppled a democratically elected socialist president. The period of military rule was so profoundly disruptive to the prospects for deeper peace in the region that stable peace would not be achievable for at least another decade because of pan-regional suspicion of the new regime in Santiago. As time wore on, however, Chile's relations with its neighbors in the region began to improve while its onceburgeoning economy began to stall. Economic difficulties, as well as international and social pressures, became too much for the Pinochet military government to support, though in its last years it succeeded in further diminishing diplomatic barriers in the Southern Cone. As Pinochet's authority waned, a warmer, more peaceful time appeared on the horizon, and suspicion of Chile dissipated rapidly with the election of Chile's first post-authoritarian president, Patricio Aylwin. Many in the region, and on the continent, viewed Chile's new government with optimism and quickly invited its leaders to participate in regional and hemispheric initiatives.

Paraguay's transition from more than three decades of rule by Alfredo Stroessner was a great deal rockier than the other transitions in the region, but it also added to the quality of the developing stable peace in the Southern Cone of the 1990s. The removal of 34 years of dictatorship in 1989 was achieved by a successful military coup, ostensibly stunting whatever hope there was for Paraguay to progress as a partner in the regional growth of the decades that followed. The swift, negative response by the international community, particularly that of its neighbors, was such that the 'caretaker' of the 
presidency was barred from standing as a legitimate, electable candidate in the first free, participatory elections Paraguay had held in its history. In March 1991, the Treaty of Asunción was signed, creating Mercosur and enshrining deep economic integration through a common market, and thanks to later developments, insisting on the rigors of democracy as a cost of doing business. The common market between Argentina, Brazil, Paraguay, and Uruguay has proved, much like the European Community or the Nordic Council, to be a significant forum in the region with a surprising breadth of influence in the relations of the Southern Cone.

The next phase of deepening democracy in the region came in the mid-2000s, and it coincided with broader and deeper levels of cooperation and integration. The earliest years of the decade were marked by the aforementioned Argentine economic collapse of late 2001 and most of 2002, which, perhaps ironically, did significant damage to a regional counterpart and important trading partner-Uruguay. Uruguay's debt default in 2003 followed closely on the heels of Argentina's, but thanks to swift and shrewd action on behalf of its then-president, Jorge Batlle, long-term damage to the Uruguayan democracy was largely mitigated. Argentina’s democracy was plunged into crisis again as a result of its economic catastrophe, but able management returned to the Casa Rosada by 2003, and Argentina began to stabilize, rebounding its economy in relatively short order. These events served to deepen regional ties, because the new Argentine President, Néstor Kirchner, buoyed by the positive signs of Argentine economic growth, convened a summit to commission UNASUR in 2005. UNASUR began as a project modeled on the 
European Union, intended to boost regional ties through customs, security, trade, and monetary integration and the organization continues to develop capacity today.

Subsequently, the elections of 2004 in Uruguay and 2008 in Paraguay would broke the one-party or one-ideology paradigms in each country and saw new presidents from new parties join the regional community with a renewed vigor for cooperation and an insistence on rule of law and respect for opposing views as protecting the legitimacies of their elections. The re-election of a Frente Amplio candidate in Uruguay in 2010 had legitimized a pluralistic democracy in Uruguay during a period of continued and growing closeness among the Southern Cone states.

Chile had largely charted its own course economically, accepting only associate status with Mercosur, but its willingness to participate in UNASUR and to be vocal in the support of democratic norms within the region were heartening signs for its neighbors in the Southern Cone. Its version of one-party rule was also broken in the late part of the decade, with the election of a conservative candidate, Sebastian Piñera; however, stability in Chile and broader integration within the Southern Cone was hardly in doubt. Although the choice to strengthen a zone of peace and shepherd it toward a pluralistic security community may not have been on the ballots in any of the Southern Cone elections of the 1990s and 2000s, what is clear is that these elections helped to firmly seal a path toward greater and more routine cooperation and de-escalation than the alternatives.

The above comparisons reveal a provocative set of parallels link these rarely compared regions and that a positive relationship exists between levels of democratization and the levels, or depth, of peace in a given region. Significant differences remain between both 
regions to be sure, however, their alignment in key indicators is both illuminating and promising for the direction of peace studies. The preliminary comparison of the historical record suggests that key characteristics of zones of peace are shared despite differing levels of economic or human development. In both regions, we observe that negative peace is the longest phase and also that the stable peace periods and the periods of progression from nascent to ascendant to mature security community also proceed rapidly. Testing for the presence of these observations in varying settings could prove a useful basis for forthcoming comparative zones of peace research. 
Table IV.1: Comparing the Nordic Area and the Southern Cone

\begin{tabular}{|c|c|c|}
\hline Variable & Nordic area & Southern Cone \\
\hline Level of human development & Very High (HDI) $^{26}$ & $\begin{array}{l}\text { Medium to Very High } \\
\text { (HDI) }\end{array}$ \\
\hline Independence (decolonization) & $1905-1944$ & 1811-20s \\
\hline State legitimacy & Very High & Very High \\
\hline Ethnic homogeneity & Very High & High \\
\hline Cultural heritage & Homogenous & Homogenous \\
\hline Interdependence & After 1980s & After World War II \\
\hline Democratization & $\begin{array}{l}\text { Extremely well } \\
\text { developed in all } \\
\text { countries since 1930s }\end{array}$ & $\begin{array}{l}\text { Well developed since } \\
\text { early 1990s }\end{array}$ \\
\hline Negative Peace & 1814/15-с. 1930 & 1870/71-с. 1985 \\
\hline Stable Peace & c. $1930-1945$ & c. $1985-1996$ \\
\hline Security Community & 1945-present & 1996-present \\
\hline $\begin{array}{l}\text { Mature Security Community? } \\
\text { Year? }\end{array}$ & Yes. 1952 & Yes. c. 2005 \\
\hline Loosely- or tightly-coupled? & Loosely-coupled & Loosely-coupled \\
\hline
\end{tabular}

\footnotetext{
${ }^{26}$ Human Development Index (HDI), defined by the United Nations after its first Human Development Report as "a new way of measuring development by combining indicators of life expectancy, educational attainment and income into a composite human development index, the HDI. The breakthrough for the HDI was the creation of a single statistic [sic] which was to serve as a frame of reference for both social and economic development. The HDI sets a minimum and a maximum for each dimension, called goalposts, and then shows where each country stands in relation to these goalposts, expressed as a value between 0 and 1.” Source: http://hdr.undp.org/en/statistics/hdi
} 


\section{Explaining the Maintenance of Peace in the Nordic Area and the Southern Cone}

This section directly compares the tested determinants of regional peace in the Nordic area against the Southern Cone. In the case of the Nordic area, all of these explanations have been tested in the context of the historical record offered here, and in at least one case, my research challenges the frequently held conclusions of other Nordic peace scholarship. This research has also tested these explanations as hypotheses about peace in the Southern Cone. That is, each of the commonly held explanations for the Nordic peace has been imposed as a generalization about peace and has been tested as a hypothesis about the maintenance of peace, and then applied here to the context of the Southern Cone. The results of the case study are fascinating, and compare favorably with the relationship of each explanation to the peace of the Nordic area.

\section{Geographical Isolation}

As was brought up near the beginning of the study-a frequent complaint about the Nordic area is its exceptionalism. The Nordics are often perceived as having no valuable parallels, and thus, their example brings few salient and applicable solutions for other regions seeking peace. That is, the Nordic states are so isolated and wholly unique that while their example is worth understanding, few useful conclusions can be drawn from a comparison with other regions. Their conditions are not replicable, so the thinking goes. This research does much to combat that perception. If the chief complaint is that the Nordic states are too strategically and geographically isolated to be significant and are thus poorly integrated into the rest of the global system, then the narrative constructed here presents contrary evidence for consideration. 
Similarly, if the argument is that the Nordic area is simply unique while other regions of the world enjoy abundant analogues, the narrative and comparisons presented here could help break down that assertion. From a geographical standpoint, the research of Bruce Olav Solheim presents just one of many examples of the region's strategic value in global geopolitics. In his book, The Nordic Nexus (1994), he uses the strategic importance of the Nordic area to the United States' Cold War agenda to make his case on the development of the Nordic security complex.

As evidence, Solheim cites that one of the first two places the Allies invaded in World War II upon the United States' entry into the war was Iceland. In a related show of importance to the oft-dismissed Nordic island, the United States compelled Iceland's assent to join NATO with aims of applying its anti-Soviet geopolitical strategy for the duration of the Cold War. Moreover, the importance of Norway as a warm water port for the present day Russian Navy and the German Kriegsmarine during World War II is nothing if not indicative of strategic importance. Finland's relationship with its neighbors, Russia and Sweden, has long determined the balance of power and the dynamic of international power and influence in the Nordic area and the Baltic Sea region. Denmark's importance to the German war objectives during the Second World War was also made obvious by its being one of the first countries to be invaded, increasing German sea access, during their campaign to dominate Europe.

Contemporarily, the geopolitical and commercial importance of the region is increasing as the Barents Sea becomes more navigable with the continued influence of global climate change. Seas that reliably froze for large parts of the year do so with less 
frequency now, and the competition for commercial navigation and resource exploitation infrastructure has begun in earnest among the closest countries, threatening a new situation that mimics the four-decades-long standoff between Russia and Norway over fisheries. In any case, if geographical isolation and insulation from geopolitics is the argument used to justify claims that Norden's example is unique and thus not useful, then this study presents a new view that the Nordic area example is relevant.

Does not the imposition of a similar charge on the Southern Cone increase that region's suitability for apt comparison? Henry Kissinger, when asked about the strategic importance of the Southern Cone, likened it to "a dagger pointed at the heart of Antarctica." The former US Secretary of State's anecdote intended to minimize the geostrategic importance of the region, but it proves illustrative for the purposes of this study. Such an anecdote reflects a sentiment among that era’s foreign policy intelligentsia that the affairs of the region had little sway on the machinations of great power politics that defined the Cold War. His deliberate mention of the (largely) uninhabited continent of Antarctica is further indicative of geographical isolation, which, when combined with its strategic insulation from global politics, combines for a similar condition to the one that many scholars attribute uniquely to the Nordic area.

If one region is largely useless as an example for comparison with others as a zone of peace, based largely on its geographical and strategic isolation, is not a comparison with a similarly remote region appropriate? That is, does not the combination of factors that relegates each region to uniqueness constitute at minimum, grounds for comparison? 
This study finds many useful conclusions from the comparison of these two geographically isolated areas, and accomplishes much in the way of tearing down this barrier to broader applicability of the Nordic case. Therefore, complaints of scholars who decry the Nordic example as unique and beyond comparison (particularly in light of geography or strategic considerations) are mitigated significantly.

Anecdotes referring to the Nordic area as "the quiet corner of Europe,” or the Southern Cone as "a dagger" pointed toward the heart of Antarctica abound, and it appears that the familiarity of these themes gives outsize importance to the claims they make. It would be difficult to argue that the Nordic area's positioning well outside of the Northern European Plain has not lessened its importance in the centuries-long battles for dominance on the European continent, it would be still more difficult to claim its separation from Greater Europe is a primary explanation for its peacefulness. Similarly, the Southern Cone's remote location on a world map might give a misleading impression of the relationship between its peace and its geographical position relative to the South American continent.

As the study in Chapter II shows, the Nordic is hardly free of geopolitical intrigue throughout its history. While Iceland remains a remote island relatively untouched by war, its position as an entry point to or from Northern Europe made its occupation of paramount importance in both World War II and during the Cold War, as it was heavily pressured into joining NATO, despite immense domestic political pressure to eschew it entirely. On the opposite end of the Nordic area is Finland, the geopolitical importance of which is made obvious by the numerous Russian/Soviet campaigns to annex it. Its decision to not join NATO or the European Union was made largely, if not solely (in the 
case of NATO) to stave off violence or tense conflict with the government in Moscow. Similarly, the positioning of Norway on the northern- and westernmost territories of the Scandinavian Peninsula and its many warm water ports (as a result of the North Atlantic Drift) have made it a strategic target for Russia, as it continues to seek warm water ports for its navy, and Germany during World War II, as a means of getting Swedish iron ore back to the Baltic Sea for its war effort. Most importantly, although a lack of strategic importance to other continental powers could explain the relative calm before the nineteenth century, this research notes that the strategic importance of the Nordic states to other warring powers was at and apogee during the area's period of greatest internal and external peace.

Testing the hypothesis that peace in the Southern Cone has been maintained because of geographical isolation has provided a similar result to that of the Nordic area. The assertion that, because of its strategic position, the Southern Cone is more peaceful or has less opportunity for conflict runs counter to the evidence presented here. Geography certainly played a role in reducing war between Argentina and Chile, the region's two major powers, but it did not protect the Southern Cone from a history fraught with conflict and violence. Chile's terrestrial barriers of the Atacama Desert and the Andes Mountains doubtless played a great role in its rare wars, its ports provided many of the country’s enemies an opportunity for militarized conflict.

Uruguay’s small size, forgiving geography (for potential invaders), important ports, and position as the fulcrum on which the balance of power between Argentina and Brazil sat made it the center of many violent conflicts during the nineteenth century. Although 
Uruguay remained entirely free of war during the zone of peace period, save a brief involvement in the last year of the Second World War, it is unclear that its geography was a central reason for its peaceful disposition.

During the zone of peace period in the Southern Cone, Paraguay's position at the extreme of the region's boundaries only rarely played a role in its involvement in conflict, which in any case was limited largely within its own borders. Its remote and relatively resourcedeficient location did help to isolate it from the external conflicts that plagued its larger neighbors, but it is not at all clear from the country's history that its location was a major factor in bringing it peace with its neighbors. After the War of the Triple Alliance concluded in 1870, Paraguay’s leadership expressly withdrew and isolated it willingly, thus, it might be better stated that the peace of the next century was dictated more by two of the subsequent hypotheses discussed in upcoming sections. Moreover, Paraguay’s last major military conflict was fought entirely because of its geographic location (the Chaco War with Bolivia, ostensibly over oil reserves that were only recently discovered to be viable).

Similarly, as recently as three decades ago, Argentina's military chose to fight a war in the extremely remote Falkland Islands. Its decision to assert its authority over these sparsely populated British territories provoked a lopsided military confrontation that ended in humiliation for the military regime in Buenos Aires. Well before the war over the Falklands, Argentina's place as a port of entry to much of South America's commodity wealth has attracted a great deal of interest from powerful geopolitical actors. 
Despite its position on the southernmost land on any continent, Argentina has not traditionally enjoyed the freedom to conduct itself without interference or conflict.

In spite of frequent claims to the contrary, this research shows that the relationship between strategic position and peace has not been strongly established as positive, certainly not during the peaceful periods in each region's history. It is not claimed here that each region constitutes a major geopolitical flashpoint resulting from intense strategic interest. The assertion that each region's place at the top or bottom of the world frees it from conflict, and indeed helps it to remain peaceful, should hold a lower position of importance among explanations for peace in the Nordic area and the Southern Cone, and perhaps elsewhere. Although the relationship between location and peace might prove strong in other zones of peace, the lack of strength in the relationship to the two regions tested here is cause for rethinking of its importance as a variable going forward. The expectation that a region is more likely to be peaceful if it occupies peripheral territory should be moderated in view of these results.

\section{Preference Structures and Political Culture}

Clive Archer cites the constraints of preference-structures of political leaders as one of the primary explanations for the Nordic peace (Archer and Joenniemi 2003: 6). In this sense, political decision makers are constrained by the confines in which they operate. That is, the norms of political behavior are reflective of the spectrum of societally accepted behaviors within states or regions. The broader context in which these constraints exist is political culture, wherein a policy maker's micro-decisions, and a government's macro-decisions are reflective of the society from which they emanate. In 
simpler terms, a policy maker is a product of the social environment in which they were reared, thus, their decision-making is indicative of the norms and mores of their ethnic or national background. In both regions, the historical record paints a clear picture of societies that grew to abhor violent interstate relations, although the impetus behind such positions remains unclear and is probably better left to a longer discussion of an anthropological or sociological nature. To that end, over the course of each region's long peace, there are clear signs of societal preferences for peace manifested in the decisions and actions of political leadership within the region and without.

The Nordic case provokes a great deal of discussion about pan-Nordic leanings toward peace, as the region's leaders repeatedly showed a willingness to pursue non-violent conflict resolution as opposed to viewing conflict as an opportunity for gain (Archer 1996: 459). The importance of willingness, as opposed to opportunity, is that the leaders in the Nordic region were predisposed to finding amenable solutions to tense conflicts. This places the avoidance of war squarely on the shoulders of Nordic decision makers as individuals, or agents, rather than being forced by events, or the national interest, or grand strategy. It is impossible to discount the roles of these factors completely, particularly given the evidence presented here, but the literature and the historical record both provide credible examples of these cultural influences playing a significant role in the avoidance of war and the deepening of peace in the Nordics. Moreover, whatever the individual's preferences, Archer (1996) and Archer and Joenniemi (2003) contend that these preferences mirrored societal preferences which grew to view the other Nordics as "family" in the latter decade of the nineteenth century, thus defining a political culture in 
the region. Particularly as the 1930s advanced, Archer asserts, the Nordic states began to rapidly move toward institutionalizing peaceful behavior, which not only colored their behavior within the region for the short term, but reflected peaceful societal values in their dealings with Europe that continue unabated today.

The literature consulted on the Southern Cone's proclivity for peace is less fully developed but nonetheless offers some valuable insight into societal attitudes toward war and peace, particularly in recent decades. Arie Kacowicz (after Holsti 1993: 19; 1996) shares in the consensus that a distinct "diplomatic culture" has come to define international relations in the region, allowing governments in the Southern Cone to resolve their disputes through talks, rather than violence (1998: 102). According to Kacowicz, and others, the South American states successfully developed theoretical guidelines for their international relations on the continent that treated intraregional disputes in an exceptional manner not reserved for extraregional governments (1998: 102). With their shared histories and cultural realities in mind, the Southern Cone has long worked inside a framework of international law that is designed to resolve disputes, no matter how heated, through non-violent recourse. The peaceful framework through which many Latin American countries have sought to bind themselves has progressed institutionally to be at the very core of its top-tier regional institutions, including CELAC, Mercosur, and UNASUR.

This comparison reveals two binding patterns between the Nordic area and the Southern Cone. The first of these patterns is that each region openly expresses willingness, indeed a preference, to resolve disputes peacefully and through a systematized pattern of 
arbitration or negotiation, within the region. The second is that both the Nordic area and the Southern Cone have developed regional institutions that clearly require and strongly encourage peaceful conflict resolution among their states, which in turn, have developed into policies that they espouse in continental relations more broadly. A key point on which the two regions diverge is in their extraregional relations. In the case of the Nordic countries, their individual cultural identities came to be reflected in their foreign policies within the region and, later, outside it. The Southern Cone however reserved its cooperative spirit in matters of war and peace for its regional neighbors, and was perceptibly more aggressive in its extraregional relations, particularly with those from outside the continent (e.g., Spain or the United Kingdom). The results do clearly point to an influence of political culture and "preference-structures" on the machinations of peace in each zone of peace. This might be a valuable tool for constructing regional peace elsewhere.

\section{Ethnic Homogeneity}

From a constructivist point of view, ethnic homogeneity is often viewed as a key determinant in the preservation of peace. Logically, this argument accounts for the innumerable examples of ethnic cleavages flaring up and leading to persecution. A shared identity, the thinking goes, necessarily lessens the opportunity for conflict between a state and its peoples or a state and other states. In both the Nordic and Southern Cone cases a lack of ethnic violence is clear, and would seem to support this claim, but the inverse is certainly true: the persecution of native tribes in Argentina and Chile caused major violent conflicts within their respective territories throughout the latter decades of the 
nineteenth century. Although this study could not confirm explicitly that a relative lack of ethnic and cultural differentiation within both regions lessened opportunity for conflict, it can affirm clearly that the presence of significant ethnic differences, at least in the case of the Southern Cone did lead to violence in the form of Amerindian pacification campaigns.

Ethnic divisions proved to be very few in the Nordics, a factor that many scholars attribute to their pacific relations over the last two centuries. A lack of ethnic differentiation on a large scale is, so the logic proceeds, a very helpful factor in not just establishing, but maintaining peace domestically and regionally. The research presented here in Chapter II found no evidence to contradict that assertion, and also notes that the last instance in which a war of aggression was prosecuted by a Nordic state was to assert control over the Schleswig-Holstein provinces, the majority of which were ethnically German. Thus, we can conclude that the last offensive war by a Nordic state was waged in hopes of subjugating a territory whose ethnic allegiances and ties lay elsewhere. In the Nordic case, we could clearly see the role that large ethnic rifts played in decisions of war, and we can also safely conclude that the lack of ethnic diversity elsewhere in the region was helpful in maintaining an orderly domestic and intraregional system. Where ethnic cleavages did surface, such as with the Sami or with the Faroese, settlements for greater autonomy were negotiated with relative ease, and did not threaten to destabilize the pacific disposition of any of the states in the Nordic region.

The colonial history that binds the South American continent makes racial and ethnic divisions impossible to ignore, or in some cases, escape. In countries such as Bolivia, 
Brazil, Colombia, and Ecuador, racial divisions lingering from the Spanish and Portuguese colonial experiences have notoriously served as a flashpoint for domestic politics. In all of those cases, significant racial divides still exist that are, in some cases, exacerbated by extreme income and opportunity inequalities or inequitable political systems that have long been tilted towards the numerically smaller Western Europeandescendant populations that have maintained a stranglehold on the political and economic systems unabated for centuries.

Where such problems arise in the states of the Southern Cone, the tensions are considerably more muted by comparison. By reputation, certainly, Argentina is thought to be predominantly European descendant and has, at times, come under negative scrutiny for viewing its preponderantly Southern European racial stock as an asset in its national identity and narrative. Although Argentina's ethnographic makeup does include indigenous peoples and mestizos at greater numbers than often assumed, this does not prevent the largest country in the Southern Cone from claiming a large, homogeneously European majority, and the likelihood for conflict along ethnic lines is significantly mitigated by this fact. People of European descent dominate Uruguay's ethnic makeup in a similar way, and minority groups are scarce but well integrated into society.

The Chilean and Paraguayan cases present the most varied ethnic dynamics in the region (Chile to a much lesser extent than any of its northern neighbors or Paraguay). The history of Spanish settlement of Chile is fraught with fierce battles and difficult-to-hold territories, owing to the country's topographical extremes. As a result, the 1870 s were a period in which, like in North America, internal stability was secured through 
“pacification campaigns” waged against the remaining indigenous tribes who still held sway over wide swathes of territory. Although there remain some ethnic tensions related to this long and bitter history in the relatively remote South of the country, Chile's slightly more diverse population has little difficulty maintaining cohesion, and when problems arise, they are generally unrelated to racial or ethnic divides. Paraguay's case presents an exception to the broader colonial experience in two ways. First, its territory was largely devoted to the creation of an indigenous and Christian nation, thus violence was held to a minimum between the colonizers and the subjugated. Second, and likely more importantly, its first president in the post-independence era forbade the vestiges of the colonial caste system and thus outlawed intraracial marriage among those of Spanish descent for as long as he ruled the country. This had the effect of creating a large ethnic melting pot that still acknowledges its indigenous roots today through recognition of two official languages: Guaraní and Spanish.

Ethnic conflict, observable to some degree in both regions, has been a key driver in violence in the past, and the removal or unique circumstances of mitigation of ethnic and racial divisions has allowed each of the Nordic and Southern Cone countries to avoid the pitfalls of their neighbors in nearby regions. It is impossible to prove a counterfactual, but one can comfortably conclude that, because ethnic divisions provoked violence in the past, the lack of significant ethnic diversity in the countries of the Nordic area and the Southern Cone today have proven helpful in lessening opportunity for conflict.

When compared with the rest of Europe, or certainly with other regions around the world, analysts of the Nordic area can point to a paucity of significant ethnic or racial divisions 
as an asset in maintaining orderly relations intraregionally and domestically. Similarly, those researching peace in the Southern Cone can observe violent conflict in a time when ethnic divisions played a larger role in consolidation, and can conversely observe a significant decline in internal conflict once ethnic homogeneity is secured. Most importantly, in either case, the only instance of cross-border militarized conflict that was conducted with explicitly ethnic causus belli during the zone of peace period or postindependence in the Americas belonged to Denmark. In sum, ethnic divisions (where extant) have been shown as causes for war both domestically and extraregionally during the zone of peace period, showing a willingness to engage violently over ethnic concerns, yet no such engagement has occurred intraregionally, suggesting a lack of ethnic concerns in a regional, cross-border sense.

\section{Interdependence and Political Integration}

A logical, but hotly debated, explanation for peace emanates from the depth of economic, military, and political ties among countries that share space in a region. Because the institutional manifestations of interdependence in both regions have already been discussed, comparison along these lines is limited here except to note that each region has shown an eagerness to participate in regionally binding institutions. To the end that interdependence fosters security community, it should be iterated here that an important feature of interdependence is the commitment to search for peaceful resolutions for conflict within a given region. In both the Southern Cone and the Nordic area, an observable set of institutions of varying breadth (ranging from sub-regional to continental or intercontinental) has committed both groups of states to such scenarios. Because the 
criteria for interdependence and integration move beyond simple nominal participation in regional institutions, the implications of those criteria are compared in the following paragraphs.

The Nordic states have held a common passport union since the 1950s and have mirrored each other greatly in the realm of domestic law making, but integration on the security and trade levels has been largely uneven. Clive Archer points to the fact that, as of 2003, intra-Nordic trade had never accounted for more than 25 percent of any one country's commerce, despite the existence of a common market (Archer and Joenniemi 2003: 18). Similarly, the history of military integration, on a regional basis, is difficult to aggregate. Sweden's absolute adherence to neutrality and Finland's sensitive relationship with Russia have both proven to be significant stumbling blocks in any quest for formalized military ties, although cooperation through a series of bilateral agreements and exercises is common between the states of the region. Thus, although political ties at the regional level (through institutions and policy coordination) have been a point of emphasis for the integration project among the Nordics, economic and military interdependence initiatives have occupied a much lower place within the overarching framework of regional integration. To be sure, interdependence has played a significant role in the Nordic area in terms of maintaining peace and developing a pluralistic security community, but interdependence is deeper than it is broad in the region.

Contrarily, the Southern Cone's regional integration and interdependence are certainly broader than they are deep, and the region lacks a specific institution devoted solely to greater cooperation among its states. This does not indicate a failing on the regional level 
as much as a lack of a discreet "Southern Cone identity." The level of formal regional integration is limited (at least in part) because of an ambiguous and still-debated interpretation of which states 'belong' in the Southern Cone-unlike the Nordic area, there is no broadly accepted-as-valid designation of what constitutes the Southern Cone-and perhaps in larger measure, by the preeminence of a broader, pan-Latin or South American identity. This cleft in identities is well represented at the institutional level, but it does not prevent close, formalized cooperation among the states of the Southern Cone, and in many cases deep ties are confined to the area rather than shared on a broader regional scale. Given the prominent and broadly negative role of the military in determining interstate relations in each of the Southern Cone states, the abundance and pace of cooperation at this level is the most surprising facet of interdependence among regional counterparts.

As the region moved toward a stable peace and later, a security community, the levels of military-to-military cooperation tracked neatly with the deepening of ties between former rival states, particularly Argentina and Chile. Evidence of heavy economic interdependence also abounds in the historical narrative of the Southern Cone, particularly alongside the movement from one manifestation of a zone of peace to the next. That Uruguay defaulted on its debt in direct connection with Argentina's default the year before could be used as sure evidence of deep economic interconnectedness in the region, but that hardly paints an encompassing picture. Where the institutional and economic meet in the Southern Cone is under the auspices of Mercosur, and its 
elimination of trade barriers among these neighbors has helped to keep all four countries very high on their respective lists of prolific trading partners.

Evidence of integration and interdependence on any level does not necessarily constitute a clear linkage to peace. For that, it is important to view each region's levels of interdependence in context. While the Nordic region exhibits greater, and more clearly defined, democratic and institutional interdependence at the political level, the Southern Cone, by contrast, exhibits greater levels of interdependence on the economic and military levels. Despite a lack of uniformity in manifestations of interdependence between the two regions, the overarching commonality is each expression of integration's clear role in, at least formally, maintaining peace. In the Nordic area economic and military ties are uneven and varied, but the political interdependence serves to normalize peaceful relationships within the region and without through a deep and long-standing framework for peaceful dispute resolution.

The Southern Cone's opposite experience with interdependence has produced the same result. Mercosur and UNASUR, both regional organizations with the intent to govern economic (and to a lesser extent, military) relations, have formalized doctrine regarding the expectations of democratic behavior, and most importantly, the resolution of interstate disputes through diplomacy while expressing an abject intolerance for political or economic change through non-democratic or violent means. In both cases, deep interdependence of varying natures has had a direct influence on the enrichment and maintenance of regional peace. Given this evidence, it appears that the existence of deep 
interdependence, rather than the nature of it, plays a significant role in lessening opportunity for conflict and maintaining peace over the long run.

\section{Satisfaction with the Territorial Status Quo}

Originally termed as an expansion and critique of the 'democratic peace' phenomenon, Arie Kacowicz’s (1995; 1998) rejoinder that asserts the importance of satisfaction (both domestically and internationally, particularly in bilateral and regional settings) with a territorial status quo is an important angle from which to assess long peace in any region. Although not explicitly included in Archer and Joenniemi's compilation of reasons for peace in the Nordic area (2003), doubtless the importance of territorial claims in lessening conflict opportunity is obvious in the region. In basic terms, the lack of dispute about territorial pertinence within or between states is deemed as a primary determinant on the health of peace in a region. Indeed, when viewed through this lens, a clear explanation emerges of how peace cannot only "break out," but also be maintained over long periods, irrespective of modes of governance. Kacowicz notes that the instances of militarized or otherwise violent conflict without disputes over territorial claims is rare; conversely, in the study conducted here, it is observable that the level of conflict during the peace period was at its most intense during disputes over territorial claims.

Revisionist claims over territory were shown to be a key propellant for conflict in the Nordic area. However, these claims did not induce intraregional war during the zone of peace period. It is worth mentioning that the last intraregional war fought among the Nordic states was over the disputed control of Norway. Since Sweden's war to reclaim Norway concluded in 1814, as has been noted here and elsewhere, the region has not 
been free of conflict. In fact, conflict in the region has threatened to bring rival states back to war on more than one occasion, most notably in the aftermath of the 1905 dissolution of the Norway-Sweden union. More frequently, heated conflict with the potential for escalation to violence has occurred between Nordic states and extraregional ones, particularly with Russia (or the Soviet Union) and the United Kingdom. In the most extreme case, Denmark fought its last wars of choice against Germany and Prussia over control of the territories directly on its southern border. Finland's more belligerent record among the Nordics is also particularly determined by disputed claims of territorial control, particularly with the Soviet Union. Whatever the overarching economic, ideological, or political concerns, the occurrence of war, and conflict of any note, in the Nordic area is predominantly linked to the dispute of territorial control, thus reflecting the importance of satisfaction with the territorial status quo.

Conflict in the Southern Cone has also largely been the result of revisionist claims over territory. At the international level, disputes with extra- and intraregional powers have, at least ostensibly, been defined by territorial disputes-most notably in the Falkland/Malvinas Islands for Argentina or the Chilean expulsion of Spain from its proximity. Disputes between Argentina and Chile over the nebulous borders of Patagonia and the Andes Mountains in the south of both territories is also a long-running theme driving conflict between the two giants of the Southern Cone, and accounts for the most serious threat to destabilizing regional peace. Domestically, the control of territory was also a source of great conflict for Argentina, Paraguay, and Uruguay, and to a lesser extent, Chile. In the countries east of the Andes, the political motives of rural and urban 
moneyed classes proved to be a spark of considerable internal turmoil throughout the bulk of the nineteenth century, and even in the twentieth century. Competing interests concerning the self-determination of provinces have long defined the political landscape, as well as the nature of conflict, for these countries in their domestic settings. Chile, like Argentina, sought to assert total control of its territory through the aforementioned subjugation of the native peoples, thus leading to long and bloody conflicts in the latter decades of the nineteenth century, despite external negative peace. In all three settingsdomestic, international, and regional-the importance of control over territory was perceptible in determining the existence of conflict.

In reviewing the historical record of each region studied here, the need for inclusion of this explanation for peace becomes obvious. Although it is not explicitly aggregated within the Archer and Joenniemi explanations for peace in the Nordic area, Kacowicz's “territorial status quo” theorem bears a clear relation to each region’s history of peace. What analysis of the historical record makes clear is that, during times of peace and times of war, conflict has been almost uniformly related to divergent claims over territorial control. Thus, despite the fact that satisfaction with the territorial status quo is often overlooked as a discreet determining variable, it proves to be particularly germane to the occurrence of conflict, war, and peace in both the Nordic area and the Southern Cone. Particularly since the onset of regional peace, the historical record bears this relationship out repeatedly, as notable conflicts only seem to become so in relation to questions of territorial claims in the Nordic area (the so-called 'Cod Wars' or the four-decade long dispute between Norway and the Soviet Union-later Russia-over fisheries) and the 
Southern Cone (the Beagle Channel Conflict between Argentina and Chile, resolved through papal mediation). Territorial disputes are not the only reason that conflict comes to a head in any region, but this study shows the distinct possibility that it is at least in some way an influencing variable. 
Table IV.2: Explanations for the Maintenance of Peace in the Nordic Area and the Southern Cone

\begin{tabular}{l|l|l|}
\hline Explanation & Nordic Area & Southern Cone \\
\hline $\begin{array}{l}\text { Strategic position } \\
\text { Ethnic composition }\end{array}$ & No & No \\
\hline $\begin{array}{l}\text { Preference structures of } \\
\text { policy makers }\end{array}$ & Yes & Yes \\
\hline $\begin{array}{l}\text { Political culture } \\
\begin{array}{l}\text { Interdependence and common } \\
\text { institutions }\end{array}\end{array}$ & Yes & Yes \\
\hline $\begin{array}{l}\text { Satisfaction with the status } \\
\text { quo }\end{array}$ & Yes & Yes \\
\hline
\end{tabular}

\section{Conclusion: New Directions for Future Research?}

What can be learned from the comparison of the Nordic area and the Southern Cone? In light of the questions asked from this study's outset, it appears there is much that can be learned from the comparison of these two very different regions. In some sense, this research breaks new ground and proves not only that the Nordic example is comparable, and thus instructive, to other regional zone of peace settings, but also that the realities of its peace might be more broadly applicable, even in regions of significantly lower levels of overall development. Conversely, the accomplishments of this study are of great importance for the greater development of zones of peace literature concerning the developing world. Not only does it succeed in eliminating a long-standing de facto barrier between peace in the developed and developing worlds, this research also establishes important linkages between explanations for peace in a developed setting and their 
applications as generalizations for the creation, establishment, and maintenance of zones of peace in the diverse global system.

At its outset, this study sought to answer specific questions about the Nordic region, the Southern Cone, and the maintenance of zones of peace. A direct comparison between the two regions has served as the medium through which the primary questions could be answered, at both the empirical and theoretical levels. A recounting of each region's history, particularly since the advent of a negative zone of peace, has shown not only the credentials for classification as a zone of peace, but importantly, the changes each zone of peace underwent in specific areas, which can be valuable to greater understanding of how to foster long-lasting peace. Relevant to the larger field of peace studies, and to the zones of peace approach to understanding regional international relations, the histories presented here have been able to offer evidence that both the Nordic area and the Southern Cone credibly qualify for analysis through the lenses of zones of peace and security communities. The discussion of each regional history of peace permitted the analysis of how that peace has been affected by specific variables, and under what circumstances these zones of peace matured from negative peace to pluralistic security community.

The cases analyzed here provide firm ground for the most prominent explanations for the Nordic peace, as well as one important generalization about regional peace and its relationship with the Nordic area, thus adding legitimacy to future approaches conducted along these lines. Perhaps more importantly Chapter III (and to some extent, this chapter) provides an important test for the wider use of these hypotheses when analyzing other 
regions. Distilled as generalized hypotheses about peace (couched in terms of lessening or heightening opportunity for conflict), these explanations have been applied as assumptions about regional peace in any scenario where it exists. Tested against the historical example of peace in the Southern Cone, the results prove favorable, and demonstrate a great number of surprising commonalities between two regions that exist as polar opposites. The research carried out in this study shows that all of the explanations for peace in the Nordic area can be applied, with minor modifications, to peace in a culturally, economically, and geographically distinct region. Further study can be valuable in the zones of peace context if guided along these same lines of inquiry.

Direct comparison of the results from each chapter leads to some surprising findings that have not yet been fully addressed by the existing zones of peace literature. Beyond providing a generalized framework for testing peace in the regional setting, specific lines of inquiry arise from the conduct of this research.

First, it is worth testing in other security communities (if found to exist elsewhere) whether time spent in the negative peace phase is preponderant among the three identifiable gradations of peace identified by Arie Kacowicz (1995; 1998; Archer and Joenniemi 2003). In both cases under analysis here, this has proven to be true. Indeed, it is worth testing whether this is (1) true elsewhere, and (2) the result of some causative process or event.

Second, a nuanced picture of the importance of interdependence is brought into focus as a result of comparing the presence of interdependence in the Nordic area and the Southern Cone. What the study shows is that democracy, and more importantly, peaceful dispute 
settlement is enshrined in each region's modes of interdependence. The Nordics show a greater presence of institutional political interdependence, whereas the Southern Cone states share stronger bonds economically and militarily than they do through regionspecific institutions. What this proves is that deep interdependence is necessary to permit the endurance of a long peace, but that deep coordination and/or institutionalization on the economic, political, and military fronts do not, in fact, exist together in either example.

Overarching the intricacies of this comparison are the significant commonalities that bind these two examples. Not only has this study proven that these two regions had more in common than is preciously expected, but that these commonalities run deeper than the more superficial comparisons of each region relative to its larger continent. This study confirms each region as a distinct and more analytically useful zone of peace than the larger continental classifications, which so often appear in comparative zones of peace research (i.e., each region's designation required fewer caveats). The results affirm the usefulness of the Nordic example in understanding at least one other zone of peace, and also show the value of the Southern Cone as a theory-testing device for prescriptions of peace conditions. These results will no doubt prove valuable for future peace research that aims to understand the contemporary, regionally fragmented global system, and to assess what conditions are necessary to create, establish, and maintain peace for a more prosperous future. 


\section{REFERENCES}

ABENTE BRUN, Diego and Michael Danielson. 2011. Uruguay and Paraguay: An Arduous Transition. In Latin America: Its Problems and Promises, Jan Knippers Black, ed., 538-565 5th Ed. Boulder, Colorado: Westview Press.

ADLER, Emmanuel. 1998. Condition(s) of Peace. Review of International Studies 24, no. 5 (December): 165-192.

ADLER, Emmanuel and Michael Barnett, eds. 1998. Security Communities. Cambridge, New York: Cambridge University Press.

ANDRÉN, Nils. 1967. Power-Balance and Non-Alignment: A Perspective on Swedish Foreign Policy. Stockholm: Almquist and Wiksell.

ARCHER, Clive. 1996. The Nordic Area as a 'Zone of Peace.' Journal of Peace Research 33, no. 4 (November): 451-467.

ARCHER, Clive and Pertti Joenniemi, eds. 2003. The Nordic Peace. Burlington, Vermont: Ashgate.

ARTER, David. 1998. Scandinavian Politics Today. Manchester: Manchester University Press.

BATTAGLINO, Jorge Mario. 2012. The coexistence of peace and conflict in South America: toward a new conceptualization of types of peace. Revista Brasileira de Política Internacional 55, no. 2 (July-December): 131-151.

BABST, Dean V. 1964. Elective Governments: A Force for Peace. Wisconsin Sociologist 3, no. 1: 9-14.

BLACK, Jan Knippers, ed. 2011. Latin America: Its Problems and its Promise. 5th ed. Boulder, Colorado: Westview Press.

BODEMER, Klaus. 2002. The Mercosur on the Way to a Cooperative Security Community? In An integrated approach to the European Union-Mercosur association, Paolo Giordano, ed., 403-417. Paris: Chaire Mercosur de Sciences Po.

BØGH, Anders and Doron Haahr. The Kalmar Union, 1397-1523. Trans. Thomas Dusgaard. Institute for Culture and Society. Aarhus, Denmark: danmarkshistorien.dk (Denmark’s History).

http://danmarkshistorien.dk/leksikon-og-kilder/vis/materiale/kalmarunionen-1397-1523/?

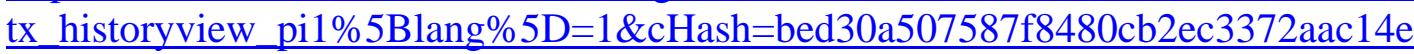
(accessed September 20, 2013).

BOULDING, Kenneth. 1978. Stable Peace. Austin: University of Texas Press. 
BROWNING, Christopher S. and Pertti Joenniemi. 2012. From fratricide to security community: re-theorising difference in the Nordic peace. Journal of International Relations and Development advance online publication, July 20. doi:10.1057/jird.2012.19 http://ehis.ebscohost.com.ezproxy.fiu.edu/ehost/external?sid=0e231fcf-c579-45c2-bd6fd068e728b88a\%40sessionmgr114\&vid=2\&hid=115 (accessed April 17, 2013).

BURKHOLDER, Mark A. and Lyman L. Johnson. 2008. Colonial Latin America. 6th ed. New York: Oxford University Press.

BUZAN, Barry. 1984. Peace, Power, and Security: Contending Concepts in the Study of International Relations. Journal of Peace Research 21, no. 2 (June): 109-125.

BUZAN, Barry. 1991. New Patterns of Global Security in the Twenty-First Century. International Affairs 67, no. 3 (July): 430-451.

BUZAN, Barry. 2011. The South Asian Security Complex in a Decentring World Order: Reconsidering Regions and Powers Ten Years On. International Studies 48, no. 1: 1-19.

BUZAN, Barry and Ole Wæver. 2003. Regions and Powers: The Structure of International Security. Cambridge: Cambridge University Press.

CARTER, David B. and H.E. Goemans. 2011. The Making of the Territorial Order: New Borders and the Emergence of Interstate Conflict. International Organization 65, no. 2 (Spring): 275-309.

DAGRE, Tor. Norway after 1905. Royal Norwegian Embassy in Washington. http://www.norway.org/aboutnorway/history/after1814/post1905 (accessed April 20, 2013). Link as of June 10, 2014: http://www.reisenett.no/norway/facts/history.html.

DEUTSCH, Karl W., Sidney A. Burrell, Robert A. Kann, Maurice Lee, Jr., Martin Lichtermann, Raymond E. Lindgren, Francis L. Loewenheim, and Richard W. Van Wagenen (Deutsch et al.). 1957. Political Community and the North Atlantic Area: International Organization in the Light of Historical Experience. Princeton: Princeton University Press.

DOMINGUEZ, Jorge I. 1998. International Security and Democracy: Latin America and the Caribbean in the Post-Cold War Era. Pittsburgh: University of Pittsburgh Press.

DOMINGUEZ, Jorge I. 2003. Boundary Disputes in Latin America. Peaceworks 50. Washington: United States Institute of Peace (USIP). http://www.usip.org/sites/default/files/resources/pwks50.pdf (accessed September 30, 2013).

EASDALE, Alex. 1999. The Role of Mercosur in the Post-Cold War Security Context of the Southern Cone. Master's thesis, Florida International University. 
ERICSON, Magnus. 2003. The Case of Norway and Sweden. In The Nordic Peace,Clive Archer and Pertti Joenniemi, eds., 24-44. Burlington, Vermont: Ashgate.

FLEMES, Daniel. 2004. Rumo à comunidade de segurança no Sul da América Latinauma corrida de obstáculos. Revista Iberoamericana 4, no. 14 (June): 182-186.

FLEMES, Daniel. 2005. Creating a Regional Security Community in Southern Latin America: The Institutionalisation of the Regional Defence and Security Policies. Working Papers Global and Area Studies no. 13 (December): 1-36.

FUKUYAMA, Francis. 1992. The End of History and the Last Man. New York: Free Press (Simon \& Schuster).

FUKUYAMA, Francis, ed. 2010. Falling Behind: Explaining the Development Gap Between Latin America and the United States. New York: Oxford University Press. Kindle e-book.

GALTUNG, Johan. 1969. Violence, Peace, and Peace Research. Journal of Peace Research 6, no. 3, (August): 167-191.

GEORGE, Alexander. 1992. From Conflict to Peace: Stages along the Road. United States Institute of Peace Journal 5, no. 6 (December): 7-9.

GEORGE, Alexander. 2005. The Method of Structured, Focused Comparison. In Case Studies and Theory Development in the Social Sciences, Alexander George and Andrew Bennett, eds., 67-72. Cambridge, Mass.: Massachusetts Institute of Technology Press.

GILLESPIE, Charles G. 1986. Uruguay’s Transition from Collegial MilitaryTechnocratic Rule. In Transitions from Authoritarian Rule, Guillermo O’Donnell, Philippe C. Schmitter, and Laurence Whitehead, eds., 173-195. Baltimore: Johns Hopkins University Press.

HILLMAN, Richard S., ed. 2005. Understanding Contemporary Latin America. 3rd ed. Boulder, Colorado: Lynne Rienner Publishers.

HIRA, Anil. 2003. Political Economy of Energy in the Southern Cone. Westport, Connecticut: Praeger.

HOLSTI, Kalevi H. 1996. The State, War, and the State of War. Cambridge: Cambridge University Press.

HOYDAL, Marita. The history of Nordic co-operation. Nordic Council. http://www.norden.org/en/about-nordic-co-operation/the-history-of-nordic-co-operation (accessed September 10, 2013).

HUNTINGTON, Samuel P. 1996. The Clash of Civilizations and the Remaking of World Order. New York: Simon \& Schuster. 
HURRELL, Andrew. 1995. Explaining the resurgence of regionalism in world politics. Review of International Studies 21, no. 4 (October): 331-358.

HURRELL, Andrew. 1998. An emerging Security Community in South America? In Security Communities, Emanuel Adler and Michael Barnett, eds., 228-264. Cambridge: Cambridge University Press.

IKENBERRY, John G. and Charles A. Kupchan. 2004. Liberal Realism: The Foundations of a Democratic Foreign Policy. The National Interest 77, no. 3 (fall): 38-49.

JERVIS, Robert. 1978. Cooperation Under the Security Dilemma. World Politics 30, no. 2 (Spring): 186-214.

JOENNIEMI, Pertti. 2003. Norden Beyond Security Community. In The Nordic Peace, Clive Archer and Pertti Joenniemi, eds., 198-212. Burlington, Vermont: Ashgate.

KACOWICZ, Arie M. 1995. Explaining Zones of Peace: Democracies as Satisfied Powers? Journal of Peace Research 32, no. 3, (August): 265-276.

KACOWICZ, Arie M. 1998. Zones of Peace in the Third World: South America and West Africa in Comparative Perspective. Albany, New York: State University of New York Press.

KACOWICZ, Arie M. 2000a. Geopolitics and territorial issues: Relevance for South America. Geopolitics 5, no. 1 (winter): 81-100.

KACOWICZ, Arie M. 2000b. Stable Peace in South America: The ABC Triangle, 19791999. In Stable Peace Among Nations, Arie M. Kacowicz, Yaacov Bar Siman-Tov, Ole Elgström, Magnus Jerneck, eds., 200-219. Lanham, Maryland: Rowman \& Littlefield.

KACOWICZ, Arie M., Yaacov Bar Siman-Tov, Ole Elgström, Magnus Jerneck, eds. 2000. Stable Peace Among Nations. Lanham, Maryland: Rowman \& Littlefield.

KAISER, Karl. 1968. The Interaction of Regional Subsystems: Some Preliminary Notes on Recurrent Patterns and the Role of Superpowers. World Politics 21, no. 1 (October): 84-107.

KANT, Immanuel. 1991. Perpetual Peace: A Philosophical Sketch. In Kant's Political Writings, ed. Hans Reiss, trans. H.B. Nisbet, 93-130. 2nd ed. Cambridge: Cambridge University Press.

KAPSTEIN, Ethan B. and Michael Mastanduno. 1999. Unipolar Politics: Realism and State Strategies After the Cold War. New York: Columbia University Press.

KELLY, Philip and Jack Child, eds. 1988. Geopolitics of the Southern Cone and Antarctica. Boulder, Colorado: Lynn Rienner Publishers. 
KUJALA Antti. 2000. The Breakdown of a Society: Finland in the Great Northern War, 1700-1714. Scandinavian Journal of History 25, no. 1/2 (June): 68-86.

KUPCHAN, Charles A. 1994. After Pax Americana: Benign Power, Regional Integration, and the Sources of a Stable Multipolarity. International Security 23, no. 2 (fall): 40-79.

KUPCHAN, Charles A. 2010a. Enmity into Amity: How Peace Breaks Out. International Policy Analysis, Dialogue on Globalization (April): 1-14. http://library.fes.de/pdf-files/iez/07977.pdf (accessed April 22, 2013).

KUPCHAN, Charles A. 2010b. How Enemies Become Friends: The Sources of Stable Peace. Princeton: Princeton University Press. Kindle e-book.

KUPCHAN, Charles A. 2012. No One's World: The West, the Rising Rest, and the Coming Global Turn. New York: Oxford University Press USA.

LAKE, David A. and Patrick M. Morgan, eds. 1997. Regional Orders: Building Security in a New World. University Park, Pennsylvania: Pennsylvania State University Press.

LEBOW, Richard Ned. 1994. The long peace, the end of the cold war, and the failure of realism. International Organization 48, no. 2 (March): 249-277.

LEVITSKY, Steven and Lucan Way. 2010. Competitive Authoritarianism: Hybrid Regimes after the Cold War. Cambridge: Cambridge University Press.

MARCONDES DE SOUZA NETO, Danilo. 2013. Regional defense integration and peacekeeping cooperation in the Southern Cone. In South America and Peace Operations: Coming of Age, ed. Kai Michael Kenkel, 64-82. Abingdon, England: Routledge.

MARES, David R. 2012. Por que os latino-americanos continuam a se ameaçarem o uso da força militar nas relações intra latino-americanas. Varia Historia 28, no. 48 (JulyDecember): 599-625.

MARTIN, Felix. 2006. Militarist Peace in South America. New York: Palgrave.

MEARSHEIMER, John J. 2003. The Tragedy of Great Power Politics. New York: W.W. Norton \& Company Publishers.

MERCOPRESS. 2010. Chile/Argentina Agree on Military Cooperation and a Joint Force for UN Peace Tasks. April 24. MercoPress Wires.

http://en.mercopress.com/2010/04/24/chile-argentina-agree-on-military-cooperation-anda-joint-force-for-un-peace-tasks (accessed November 1, 2013). 
MERCOPRESS. 2012. Paraguay begins drilling for oil in the Chaco next December. October 17. MercoPress Wires. http://en.mercopress.com/2012/10/17/paraguay-begins-drilling-for-oil-in-the-chaco-nextdecember (accessed January 10, 2014).

MILLER, Benjamin. 2007. States, Nations, and the Great Powers: The Sources of Regional War and Peace. Cambridge: Cambridge University Press.

MINISTRY OF PETROLEUM AND ENERGY. 2013. Norway's Oil History in 5 Minutes. Kingdom of Norway. http://www.regjeringen.no/en/dep/oed/Subject/oil-and-gas/norways-oil-history-in-5minutes.html?id=440538 (accessed November 1, 2013).

NATIONAL ARCHIVES OF NORWAY AND SWEDEN (Archives). 2005. 1905: Norway, Sweden In Union. National Library of Norway and Royal Library of Sweden/Swedish National Library. http://www.nb.no/baser/1905/index.html (accessed April 12-25, 2013).

a. 2005. Timeline. National Library of Norway and Royal Library of Sweden/Swedish National Library. http://www.nb.no/baser/1905/tidsl_e.html (accessed April 12-25, 2013).

b. 2005. Timeline: 1814-1903. National Library of Norway and Royal Library of Sweden/Swedish National Library. http://www.nb.no/baser/1905/tidsl/1814_1903/frindex_e.html (accessed April 12-25, 2013).

NYE, Joseph S., ed. 1968. International Regionalism: Readings. Boston: Little, Brown and Company.

O’DONNELL, Guillermo, Philippe C. Schmitter, and Laurence Whitehead, eds. 1986. Transitions from Authoritarian Rule: Latin America. Baltimore: Johns Hopkins University Press.

OELSNER, Andrea. 2003. Security in Latin America: The Development of a Zone of Peace in the Southern Cone. London: University of London. Doctoral Thesis.

OELSNER, Andrea. 2005. International Relations in Latin America: Peace and Security in the Southern Cone. New York and London: Routledge. Kindle e-book.

OELSNER, Andrea. 2007. Friendship, Mutual Trust and the Evolution of Regional Peace in the International System. Critical Review of International Social and Political Philosophy 10, no. 2 (June): 257-279.

PHILLIPS, Nicola. 2004. The Southern Cone Model: The political economy of regional capitalist development in Latin America. New York: Routledge. 
PORRATA-DORIA, JR, Rafael. 2005. Mercosur: The Common Market of the Southern Cone. Durham, North Carolina: Carolina Academic Press.

RAPOPORT, Anatol. 1992. Peace: An Idea Whose Time Has Come. Ann Arbor, Michigan: University of Michigan Press.

REID, Michael. 2007. Forgotten Continent: The Battle for Latin America's Soul. New Haven, Connecticut: Yale University Press.

REITER, Dan. 1994. Learning, realism, and alliances: the weight of the shadow of the past. World Politics 46, no. 4 (July): 490-526.

RESENDE-SANTOS, João. 2002. The Origins of Security Cooperation in the Southern Cone. Latin American Politics and Society 44, no. 4, (Winter): 89-126.

RUSSETT, Bruce, John Oneal, and David R. Davis. 1998. The Third Leg of the Kantian Tripod for Peace: International Organizations and militarized Disputes, 1950-1985. International Organization 52, no. 3 (summer): 441-467.

SCHEINA, Robert L. 2003. Latin America's Wars Volume I: The Age of the Caudillo, 1791-1899. Dulles, Virginia: Potomac Books.

SCHMITTER, Philippe C. and Terry Lynn Karl. 1993. What Democracy is ... and is Not. in The Global Resurgence of Democracy, Larry Diamond and Marc Plattner, eds., 49-62. Baltimore: Johns Hopkins University Press.

SCHULZ, Michael, Frederik Söderbaum, and Joakim Ojendal, eds. 2001. Regionalization in a Globalizing World: A Comparative Perspective on Forms, Actors and Processes. London: Zed Books.

SCHWELLER, Randall L. 2011. Emerging powers in an age of disorder. Global Governance 17, no. 3 (July-September): 285-298.

SCHWELLER, Randall L. and Xiaoyu Pu. 2011. After Unipolarity: China's Visions of International Order in an Era of U.S. Decline. International Security 36, no. 1 (Winter): 41-72.

SINGER, Max and Aaron Wildavsky. 1993. The Real World Order Zones of Peace, Zones of Turmoil. Washington: CQ Press.

SKIDMORE, Thomas E. and Peter H. Smith. 2005. Modern Latin America. 6th ed. New York: Oxford University Press.

SKREDE GLEDITSCH, Kristian. 2002. All International Politics Is Local: The Diffusion of Conflict, Integration, and Democratization. Ann Arbor, Michigan: University of Michigan Press. 
SMALL, Melvin and David J. Singer. 1976. The War Proneness of Democratic Regimes, 1816-1965. The Jerusalem Journal of International Relations 1, no. 4 (summer): 50-69.

SOLHEIM, Bruce Olav. 1994. The Nordic Nexus: A Lesson in Peaceful Security. Westport, Connecticut: Praeger.

STARR, Harvey. 1992. Democracy and war: Choice, Learning and Security Communities. Journal of Peace Research 29, no. 2 (May): 207-213.

STAVRIDIS, James. 2013. High North or High Tension? How to head off war in the last frontier on Earth. Foreign Policy. October 13. http://www.foreignpolicy.com/articles/2013/10/21/high_north_or_high_tension_arctic_co mpetition (accessed December 1, 2013).

SUNDELIUS, Bengt, ed. 1982. Foreign Policies of Northern Europe. Boulder, Colorado: Westview Press.

SZUSTERMAN, Celia. 2000. Carlos Saúl Menem: Variations on a Theme of Populism. Bulletin of Latin American Research 19, no. 2 (April): 193-206.

TAVARES, Rodrigo. 2014. Security in South America: The Role of States and Regional Organizations. Boulder, Colorado: First Forum Press.

TERRADAS, Nicolás. 2010. El Dilema de la Seguridad en América del Sur: Una revisión del debate sobre la 'larga paz’ sudamericana. Buenos Aires: Universidad Torcuato di Tella. Master’s Thesis.

TUCICISNY, Andrej. 2007. Security Communities and Their Values: Taking Masses Seriously. International Political Science Review 28, no. 4, (October): 425-449.

UNESCO. Jesuit Missions of La Santísima Trinidad de Paraná and Jesús de Tavarangue. United Nations. http://whc.unesco.org/en/list/648 (accessed August 10, 2013).

UNITED NATIONS DEVELOPMENT PROGRAMME. 2013. 2013 Human Development Report. Human Development Report Office. Washington: United Nations.

UNITED NATIONS POPULATION DIVISION. 2009. Classification of Countries by Major Area and Region of the World. Department of Economic and Social Affairs. New York: United Nations.

UNITED STATES COAST GUARD. 2013. United States Coast Guard's Vision for Operating in the Arctic Region: Arctic Strategy: Ensure safe, secure, and environmentally responsible maritime activity in the Arctic. Washington: United States Coast Guard. 
VÄYRYNEN, Raimo. 2000. Stable Peace through Security Communities? Steps Toward Theory Building. Occasional Articles 18, OP3: 157-188. South Bend, Indiana: Joan B.

Kroc Institute for International Peace Studies at the University of Notre Dame.

WALT, Stephen M. 2009. Alliances in a Unipolar World. World Politics 61, no. 1 (January): 86-120.

WEINTRAUB, Sidney. 2000. Development and Democracy in the Southern Cone: Imperatives for U.S. Policy in South America. Washington: Center for Strategic and International Studies.

WIBERG, Håkan. 2003. A Baltic Sea Security Community? Paper, presented at the International Conference "Deepening the Process of Integration in the Baltic Sea Region: Roles of Actors, Competition between Institutions and the Issue of Identity" Szeczecin, Poland. December 11-14.

http://www.uibk.ac.at/peacestudies/downloads/peacelibrary/balticsea.pdf (accessed August 1, 2013).

WRIGGINS, Howard, ed. 1992. Dynamics of Regional Politics. New York: Columbia University Press. 